
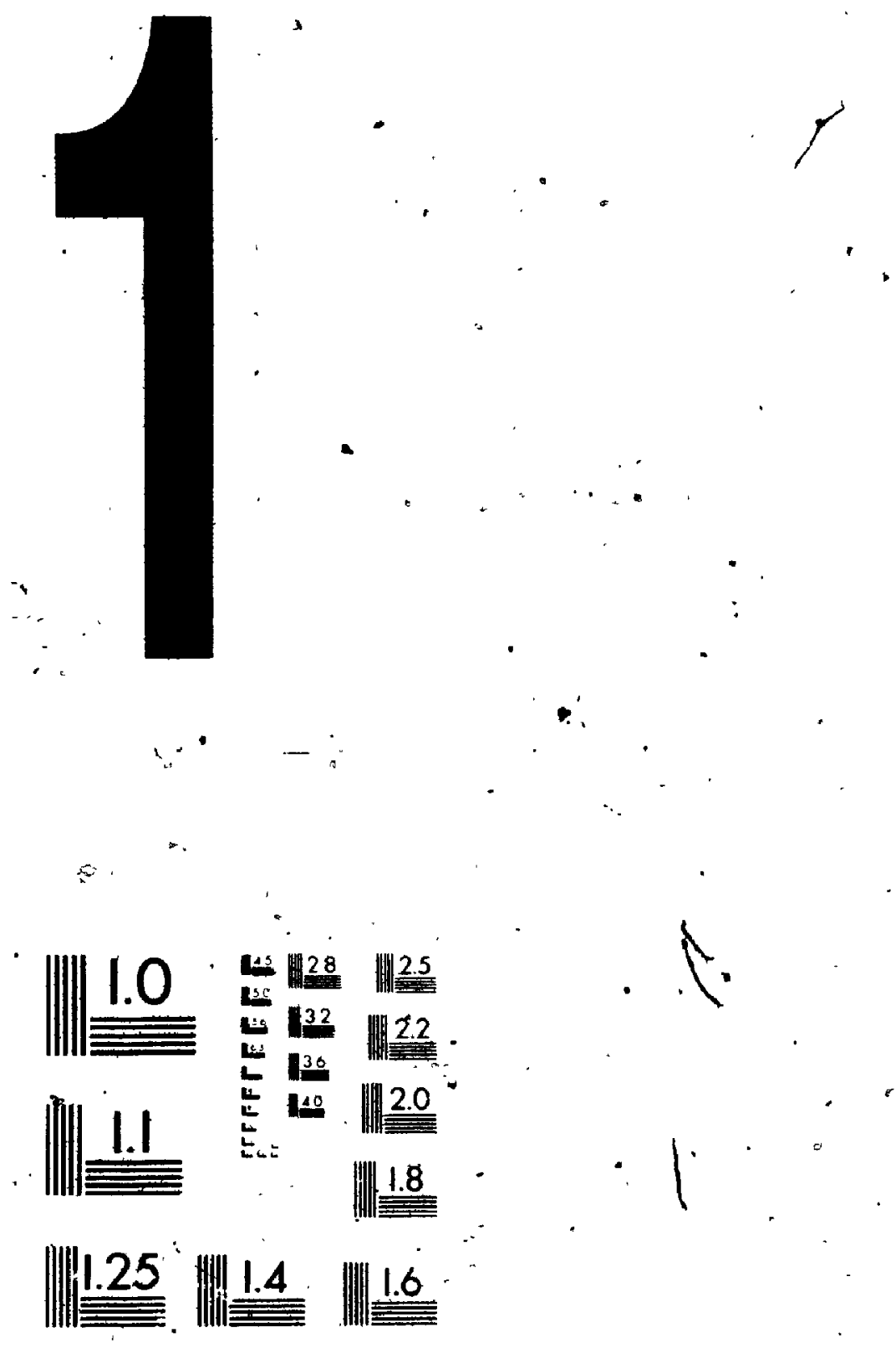

I MicRocopy Resolution test Chapt

NATIONAL BUREAU OF STANDARDS

STANDARD REFERENGE MATERIAL T010a (ANSI and ISO TEST FHART NO 2 ) 
National Library

of Canada

Canadian Theses Service

Ottawa, Canąa

K1A ON4

:
Bibliothéque nationale di Canada

Services des thèses canadiennes

\section{CANADIAN THESES}

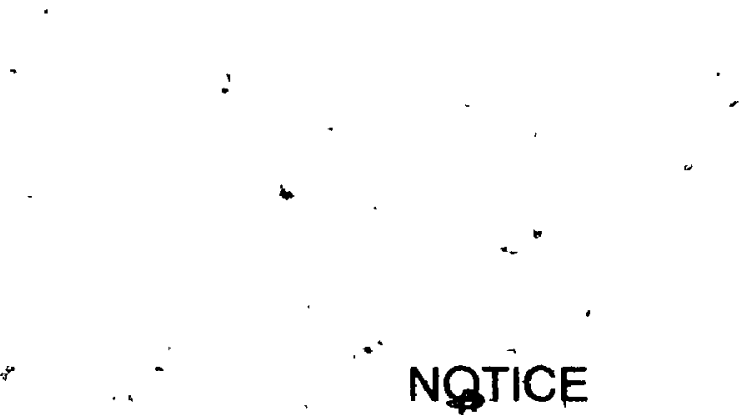

The quality of this microfiche is heavily dependent upon the quality of the original thesis submitted for microfilming. Every effort has been maqe to ensure the highest quality of reproduction possible.

If pages are missing. contact the university which granted the degree.

Some pages may have indistinct print especially if the original pages were typed with a poor typewriter ribbon or if the university sent us an inferior photocopy.

Previously copyrighted materials (journal articles, published tests, etc.) are not filmed.

Reproduction in full or in part of this film is governed by the Canadian Copyright Act, R.S.C. 1970, c. C-30.
S'il manque des pages, veu
sité qui a conféré le grade.

La qualité d'impression de certarnes pages peut laisser désirer, surtout si les pages orıginales ont été dactylographié àtaide d"un ruban use ou si l'universite nous a fait parve une photocopie de qualité inférieure

Les documents qui font déjà l' objelel d'un droll d'auteur (artıc' de revue, examens publiés, etc.) ne sont pas microfilmé:

La reproduction, mème partielle, de ce microfilm est soum à la Loi canadienne sur le droit d'auteur, SFC 1970, c C--i
THIS DISSERTATION HAS BEEN MICROFILMED EXACTLY AS RECEIVED
La qualité de çette microfiche dépend grandement de la qual de la these soumise au microfilmage. Nous avons toul falt po assurer une qualite supérieure de reproduction 
THE PROCESS OF ADAPTATION OF AN ETHNIC GROUP:

THE CASE OF SPANIARDS IN OTTAWA "

by

Ana Isabel Guada Martinez

A thesis submitted to the Faculty of Graduate studies in partial fulfillment of the requirements for the degree of Master of Arts

$$
\begin{gathered}
\text { Department of Sociology and Anthropology } \\
\text { Carleton University } \\
\text { Ottawa, Ontario }
\end{gathered}
$$

(c)

December 1985 

The undersigned recommend to the Faculty of Graduate Studies and Research acceptance of the thesis

The Process of Adaptation of an Ethnic Group:

The Case of Spaniards in Ottawa

Submitted by Ana Isabel Guada Martinez

in partial fulfilment of the requirements for the degree of Master of Arts

$-$

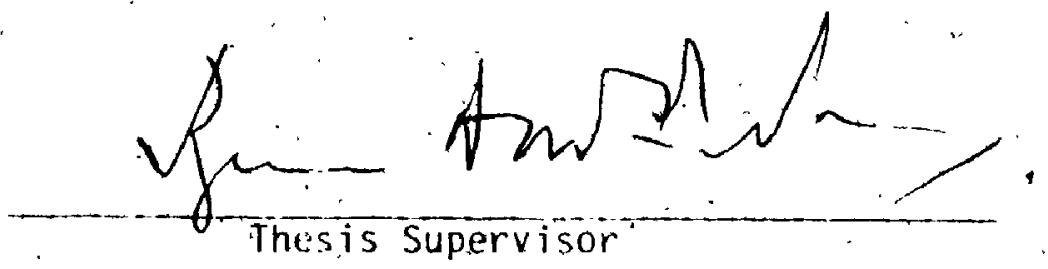

Cha inmate, Department of

Sociology

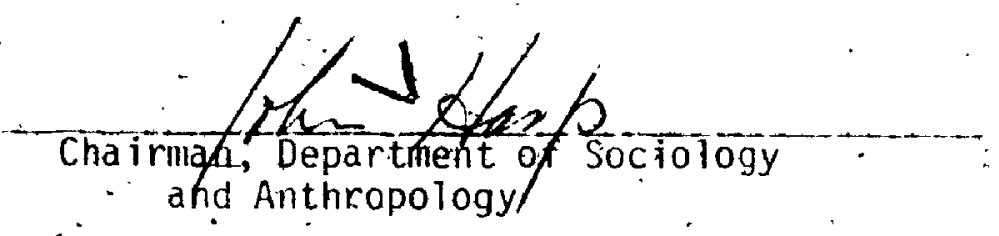

Carleton University

January, 1986 


\section{ABSIRACI}

This is a study about the adaptation of immigrants in Canada, the Spaniards in Ottawa, with special focup on their acculturaticn, occupational adjustment andror economic adaptation to the rost society, and how this process of cultural and economic adaptation occurs simultaneously with the mantenance of ethnic ties.

The process of integration of ethnic groups into the wider society refers to participation in the different damensions of the society: that is, integration into socal, econonic, cultural and political fife. Full social and political ancorporation rarely occurs in the case of first generation loriginal aduiti immigrants. Therefore, this study concentrates on tre adaptation into the cultural and economic sphere of the host society, assuming that there is a very low degree, of socal and political integration, in the case of the ottawa spanish community.

Based on secondary data we have described the immigration of Spanish people, only those born or residing in spann, to Canada during a 26 year perjod (1957-1983), and using semtstructured interviews (31) and participant observation, we have analysed the level of aeculturation, occupational adjustaent and ethnic attachment of the Spanish immigrants in ottawa. These two processes; integration and ethnic attachment, were measured by various indicators such as oceupational status, satisfaction with 
job, uge of official dinguages, intention to return to the homeland, personal relations and ethhic community. involvement, among others. It was found that length of residence in Canada, year and age of forrival, and other variables are apparently less Important than education and occupational status, in the cultural and économac integration of Spanish immigrants to the host society, and their maintenance of ethnic ties as well.

3.

- This should be considered an exploratory study of the - Spanssh comaunity, which could serve as a basis for further $\therefore$ research on this ethnie group in Canada. 


\section{ACKNQWLEDEEEMENIS}

I would like to express ny deepest appreciation to my thesis supervisor, Professor Bruce A. Mefarlane, for all his encouragenent, support and guidance in the realization of this thesis. Also to Protessor Victor Da Rosa of the University of Ottawa whose experience with ethaic group studies, especially Southern Europeans, has been extremely valuable.

To the Spanish community in Ottawa, people and institutions, all my gratitude for their collaboration and kindness. They proxided most of the information whach made this study possible.

This thesis could not have been completed without the moral support and motivation, of my children Carlos and Carla. Finaliy, my special thanks and gratitude to David Williams for his encouragement, faith and persistance throughout my years as a M.A. Student. 


\section{IABLE_DF_CONIENIS}

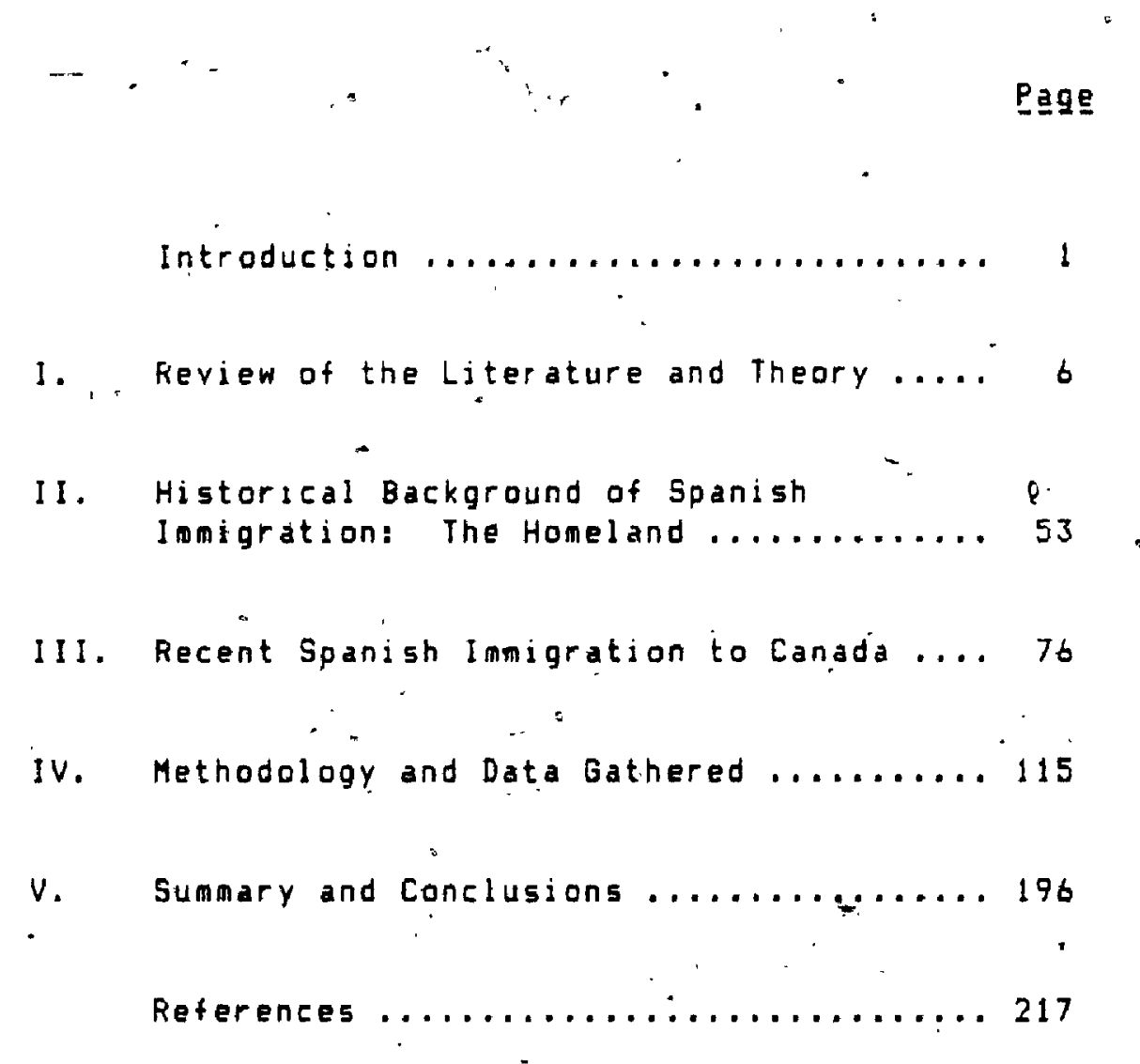


I므늘

Page

3.1 Number of Spanish Landed Imigigants in Canada

- by year of arrival (1957-1983) ............... 84

3.2 Citizenship of Spanish landed immigrants by

3.3 Settlenent of Spanish Immigrants in Canada by Country of Last Pérmanent Residence (1957-1983) ... 87

3.4 Distribution of Spanish Immigrants by Sex by Country of Last Permanent Residence (1957-1983) ...990

$3.5^{\circ}$ Distribution of Imaigrants from Spain by Áge and Country of Last Permanent. Residence ............90

3.6 Intended Occupation of Landed Immigrants by Ethnic Drigin (1957-1961) ........................ 92

.3.7 Preferred Intended Occupations of Landed Immarants by Country of Last Permanent Residence (1962-1983).

3.8 Intended Decupation of Landed Immigrants by Country of Last Permanent Residence (1962-1975) ......... 95

4.1 Distribution of the Sample by Length of Residence.

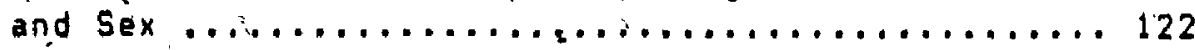

4.2 Distribution of the "Sample by Sex and Level of Education ............................. 124

4.3 Distribution of the Sample sy Motives of

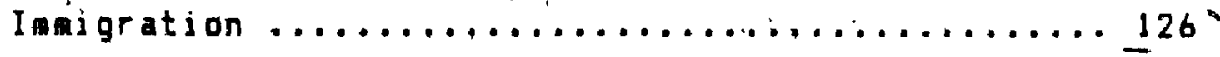

4.4 Distribution of the Sample by Area of Residence ... 129

4.5 Distribution of the Sample by Last Job Held Before Arriving in Canada, and Sex ................132

4.6 Distribution of the Sample by Sex and Fir.st

- Dccupation in Canada .......................134

4,7 Distribution of the Sample by Sex and Present occupation .......................... 137

4.8 Present Employers of the Spanish Respondents by Sex 140 
4.9 Distribution of the Sample by Knowledge of English and French at Arrival .................. 150

4.10 Distribution of the Sample and Present Knowledge of English by sex ...................... 151

4.11. Distribution of the Sample by Length of Residence and Present knowledge of English .............154

4.12 Distribution of the Sample by Satisfaction with Life in Canada by Length of Residence ........... 156

4.13 Food Habits of the Sample by Length of-Residence.. 161

4.14 Dastribution of Sample by Food Habits and Exogany...162

4. 15 Spanish Respondents Classified by Sex and Ethnic origin of their Eest friends .......................

4.16 Membership. in Spanish Cultural Center and Attendance to Ethnsc Church of Spanish Regpondents

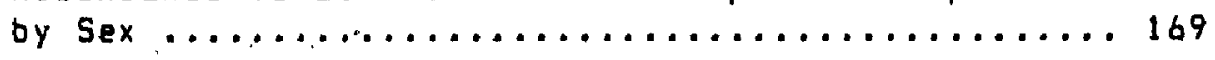

4. 17 Negative Aspects of 'Spain for a Sample of Spanish Immigrants in ottawa .................. 177

4.18. Level of Dccupational Adjustment of a Sample of Spanish Immigrants by Sex ................ 183

4.19. Level of Acculturation of a Sample of Spanish Immigrants in ottawa by $\operatorname{sex} \ldots \ldots \ldots \ldots \ldots \ldots \ldots \ldots 185$

4.20 Level of Ethnic Attachment of a Sample of Spanish Inmigrants by $\operatorname{sex} \ldots \ldots \ldots \ldots \ldots \ldots \ldots \ldots \ldots \ldots \ldots \ldots 187$

4.21 Distribution of the Sample by Acculturation and Occupational Adjustment by ${ }^{\dagger}$ Sex ................ 188

4:22 Level of Acculturation of the Sample by Sex. and Length of Residence ..................... 189

4.23 Occupational Adjustment and. Ethnic Adjustment of a Sample of Spanish Immigrants in Ottawa by Sex .... 190 


\section{INIRODUCTION}

- Although relatively heavy immigration to Canada is recent lnot more than twenty years), Spain and Canada have been associated for centuries, beginning with the voyages of the Basque "ishermen to Canada"s Atiantic coastal waters and Span's exploration of the Pacific coast.

.

When ass migration from Europe started in the nineteenth century, the Spaniards (mainly from Galicia and northern provinces), generally weot to Latin America. This wave of • emigration, almost exclusively to "South America, was later. substituted by tine migration of labour to Western Europe, ispecifically to France and Germany in the 1950's.

Spain has provided few imigrants to Canada, compared to 2 other ethnic groups. As a consequence, theire are fewer studies about Spanish immigrants in Canada in relation to other South European groups such as the Italians, Fortuguese, and Greeks. Because of this lack of literature on the spaniards, in.most studies they are often fused with other ethnic groups or just grouped in the "others". category.

Hence, information about other South European groups - (portuguese, Italian ard Greek) in Canada will be used in this study, assuming that there are certain similarities among these groups. Some of the common charecteristias found in south European imagrantg in conada are: the Latin background, the 
recentness of arrival imeibers of these groups tend to be relatively youngl, their ethnic past is more immediate, their ties to the ethnic group ar in general stronger; and they have less Canadian experience; the same Catholic background lexcept the, Greeks); "the experience of dictatorial governments in the home society; a low level of education cospite the restrictions of post-war immigration concerning education; South Europeans generally canc sponsored by relatuvesl; and finally they have experienced one of the greatest degree of exploitation in the work area: low job status and hagli job segregation 'Rejtz, 19801 .

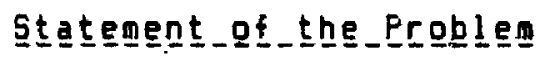

In this research it is intended to examine some of the general characteristics of the immsgration process, focussing on the employment situation of the Spanish ethnic group llatin American exclyded), with special reference to the case of ottawa. We will attenpt to study the integration into the econonic and cultural life of the host society of one sector of the Spanish population in Canada: that is,first generation, or second generation Spanish immigrants who arrived in Canada after fifteen years of age.

The objectives of the study are to describe the occupational adjustiment of the members of the Spanish ethnic group, and its relation to their levejof acculturation and aintenance of ethnic ties. 


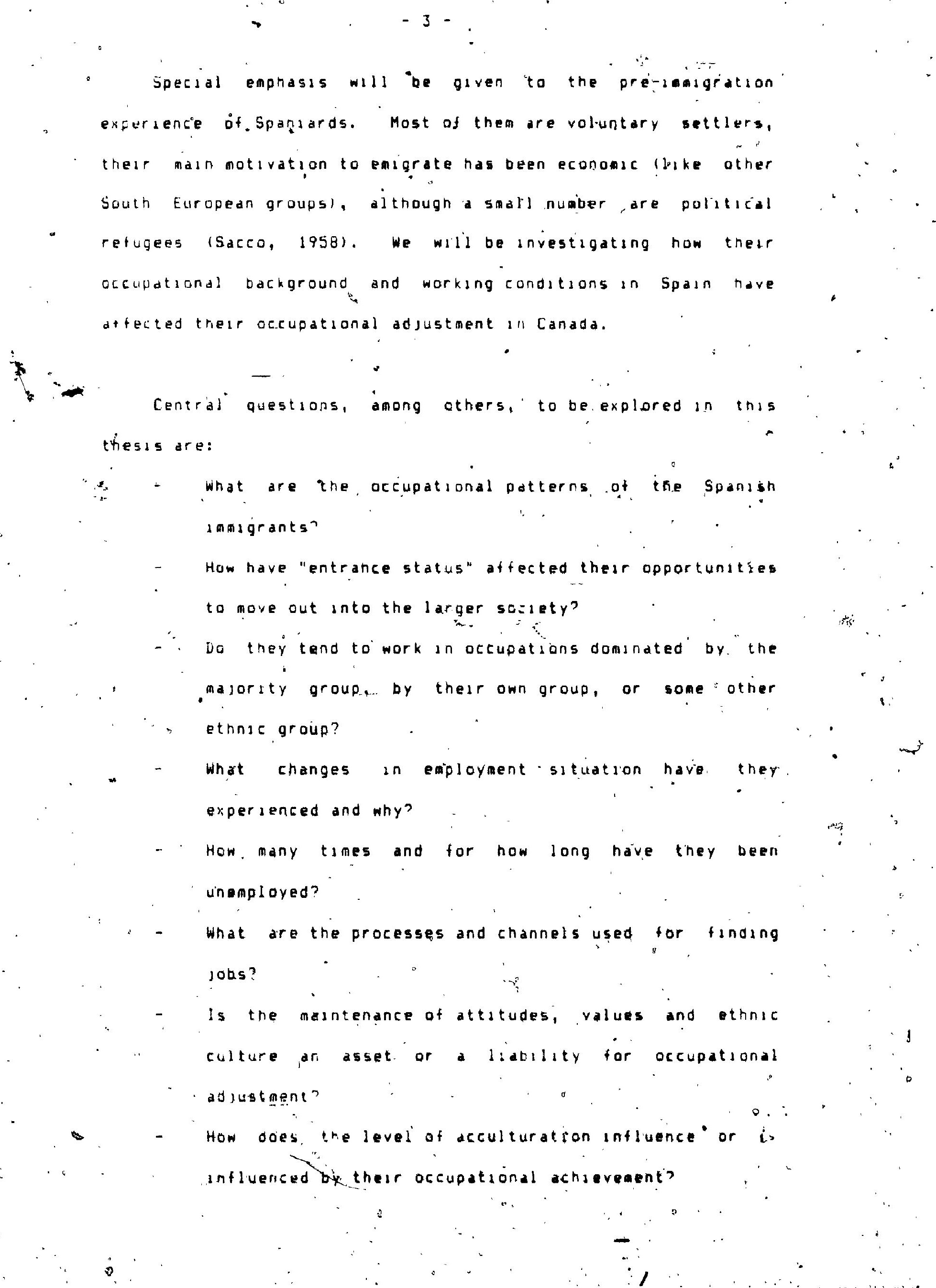


- inis thesis la structurad in five, chipters as followsil Chapter Une exalones the man theoretical approaches and evidence on inagiation in capitalist societies, stratification or ethnic juequalit, ociupational segregation, wajority group control, ethnic integration, acculturition ind ethicic attachant.

Chapter Two ds intendeg os an historical review of the factors (pusk and pull) that have accounted tor the eaigration of spaniards; tocus wijl bo placed on the cocio-economic situation in Spain at the tiae larger groups of Spaniarda entered canada (1963-1976). An analysis of the prevalent value systei in Spanish society is considered important because those values aro brought trow the homeland, and often arpipreserved and adintained lat 'Ieast partially). This background, may influence the inasgrants general adaptation' to the host society. specifically their economie absorption.

Q Chapter Three 1. a presentation of the oenéral characterdstics of the spanish imaigration in canada within the overall context of inagration is.ce World War II, although d brief description of the early spanish exploration and the Iowgration of Spaniards prior to the 1940. will also be given.

Avaldable' statistics. on the Spanish ethnic oroup will be" shown. particularly: patterns of settlenent, déographic characteristics, Intended occupation. After this oeneral view of the Spanish imagration. to canada, we will concentrate, on a 


\section{$-5:$}

descraption of the setting; that is, description of the ethnic community in ottawa.

Chapter four includes an analysis of the interviews pointing out the major tendencies found, and also particular individual cases that are considered typical (case history) of partacular situations.

The first part of the analysis refers to the general background of the immigrants: their innigration experience, demographic aspects such as age, time of arrival, settlement in Canada, level of education, among others. The second part deals with the process of occupational adjustment and general job satuation of the Spanish immigrants lintended and first ocefpation, present. job., job seeking behaviour, etc.) Fanally, the degree of maintenance of the ethnic culture and the level of acculturation is assessed. In thas chapter, overall trends are noted, and because of the. exploratory nature of this study, inost of the data analyses are descriptive.

Chapter five will. be dedicated to summarizing the information presented in the preceding chapters and the main findings of the research. 


\section{SHAPIER_DNE}

REVIEW_OF_IHE_L IIERAIUEE_AND IHEQRY

Spanish imasgration to Canada as antioned above is one of the leat etudied anong oll the groups of ianigrants to cancda, perhaps because of jts shall size when compared to other ethnic groups.

He havebeen able to Jocate only two (2) M.A. theses that have specifically focused on Spaniards in Canadai Saccó in 1958 and Ferninder in 1972 . These studies refer to the Spaniardicin Quobec and Montreal, and neither of thea comsidera in detail the ioccupational. adjustaent of this ethnic group. Even in Spain, very tew studies haveboen dedjcated to the spanish imaigration to North America in general wost bf the literature refers to Western Europe labour igration IDiaz Plaja, 1974; MuKaz, 1972 Kubio., 19741 .

In the United states the ajority of the otudies on Spanden speaking groups are concerned only with Mexican, Puerto Rican, Cutan and other Latin American, ingigrants. IMcTaggart, 1979; Wilson and Portes, 1980, Fog9, 19741.

In Canada, Grace Anderson has included Spaniards together with other Spanish-speaking groups in Canada (1973, 1977,1974), focusing mainly on ethnico oroanizations, pthnic preses and oeneral characteristics of this linguletic group. In our opinion. there ts a need for specific research on spaniards frov spain, 
separated from other spanish-speaking groups; there are unique regional elements that differentiate the Latin American countries from spain, despite the elements of common history as well as traditions ańd similar legal background, language, religion, ete.

Specific research on Spanish immigrants in Ottawa ds also lacking with the exeeption of a study about the working conditions and occupational background of several ethinic groups, by the Ottawa Carleton Services Organization in 1981. Eut again, Spaniards and Latin Americans are ccnsidered as one group; therefore, the results of this study are applicable in general to Spanish-speaking groups and not specifically to spaniards, that is, immigrants trom Spain.

Since few studies are available with respect to spanzsh inmigrants in canada, the topic should be approached with flexibility, and developed in an exploratory manner, and immigration and economic adaptation will be viewed within the context of maintenance of ethnic culture and level of acculturation of spanish immigrants in ottawa.

\footnotetext{
(Thus; this research may be characterized as exploratory and is directed not only to the description of a small. immigrant group. in ottawa, their bistory, their formal institutions and manifestations of spanish culture, but also is concerned. with their occupational adjustment and some of the factors affecting this process.
} 


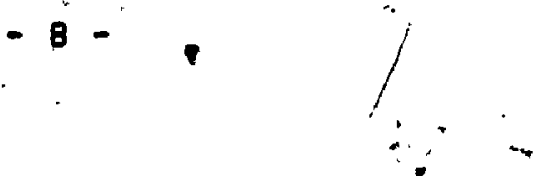

The notions provided by the existing literature on umigration, labour force status, occupational adjustaent of Immigrants, acculturation and maintenance of ethicic culture, among other general zssues, will serve to situate Spanish. immigrantg within the overall context of Canadian multicultural society.

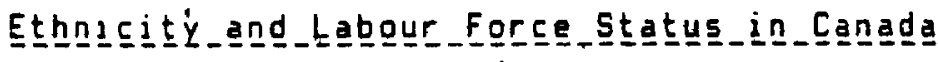

West European and North American capjtaljst countries have long employed foreign workers from underdeveloped areas of Europe (especially Southern Europe), and from Thard World countries.

Most of the immigrants contribute significantly to the productivity of the country into which they immigrate. Richmond (1974) has noted hon immigrants act to push the local labour. force, and they oceupy botton positions which aredifficult to f1ll with the local labour force.

When an immigrant considers coning to Canada one of his/her major considerations is the "availability of work and the prospective income a job would provide" (Anderson, 1974). As * Gross puts, it, "it is an occupation which gives aceess to a Iiving, level of comfort, prestige and life chances" (1958: 605). Occupation.in.industrial societies is so closely related to income, education and prestige that it has beciome a major deterainant of social status. Position in the system of social stratification apart from ascribed statuses such as sex, age and 
ethnicorigin, rests upon achievenent in the work world.

As noted before, the individual position in the economic structure is among other factors affected by ethnic origut Economic inequality among ethnic groups can be described as "the position of an ethnic group in the economic hierarchy, and in terms - of differential opportunities for mobility to higher levels: The economic position of each ettric group changes over time and it is affected by continuing patterns of immigration, and by opportunities for economic mobility". (Restz, 1980b)

- Canada in common with most other pluralistic socjeties is ethnicly stratified. According to Jọnn Porter there is close association between ethnicity and economic status is Canada:

"Where ethnic differentiation has ariseri, as in the United States and Canada, through immigration, there has been a host or charter group that got there farst and determined the conditions under which the other groups might. enter. These conditions ranged from unifree slaves immigration to free selective jmajgration under which the host society made judgements about the appropriateness of various groups for particular jobs. Migration is an economic process by which one factor of praduction moves with on other factor capital. The entire process is selectuve on which people get sorted out according with their bellevedin qualities or aptitudes for different economic activities." (1965: 33)

Post World War II immigration has tended to reinforce the existing tendency for those of British origin to be overrepresented in the managorial, professional, and higher levels of. occupational status, relative to those of Southern European origin (Richmond, 1970: 22). Wrien Porter analysed the. differential occupational cistribution of ethinic grpups he. 
considered. group overtepresented when jt had, higher proportion at a particular occupational level than that of the total Jabour force $11965,76 \mathrm{~d}$.

Blishert (1970) also analysed the relationship betwean sockal class and ethnicity, country of birth of imaigrants, and religion. Like Porter he considers that occupational position is affected by ethnic affiliation, country of birth and other ascribed social charicteristices

"The escribid statuses which a person occupies at a particular point in tine are not rendanly assorbed there, is - degree of correlation between theing and the ascribed status patterns are related to occupaisonll position. White, Anglo-Saxon Protestants for example are nore likely to achieve high oceupational status than other ascribed status combinations." (1970: 112)

To explan differences in the economic position of different ethnig groups, discrimination as often considered a important factor (181sben; 1970;.Reitz, 1980a; 81au and Duncin, 1967). The Anglo-5axon attitude toward South European ingigrant has been shown to be dess poutive than the attitude toward Northera Europeans (Reitz, 1980ai 1980b, 1982, Pineo, 1977). Although there is some evidence of discrimination eqainst certain ethnic asnorities, the level of overt discrimination mas decreased significantly" (Richmond, 1967, pp. 78-84). This prajudice in covert foras of discrianation retards large scile integration of the menbers of ethnic anorities in the public iphere of the wajority. society. There is no evidence of spariards who have acquired the requsite sklls, achievenent of high-ranking 
(elitel positions in the econoaic and political spheres of the nost society. According to Hughes it is in the private sphere of informal clubs, cliques and prigary. social relationships of the aajority ethnic group that a high. level. of prejudice and discriaination, and high level of social distance on the part of the ajority neabers, continues to operate, including only a fow meibers of ethnic minorities (1974:181). There are covert forme of discriaination, especially against Southern European ianigrants, who continue to bo treated as unakillod manual laborers. They are expacted to till "mental" labour and construction jobs (e.g. cleaning: Portugueise and Spaniards).

When ianigrants of variousethnic origins; but similar educational backgrounds, and previous occupational level are differentially stratified in the occupational structure, it is deemed to be evidence of the existence of discrimination (LI, 1978 ).

The explanation for discriaination and continued low

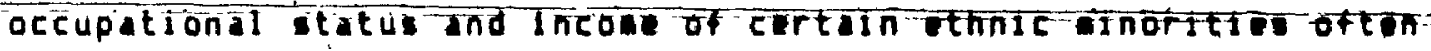
involves the theory that the ajority oroup controls the occupational reward systea, Porter has refierred to the "gatekfong" positions of the wajority group within organizations, and how they have the power to exclude some and include other ethnic oroups. Roitz (1981) has evaluated axtensively the anority group control theory in his Toronto research on Italiane, Portugues," Greeke, Nest Indians, Chinese and other ethnic minoritios. This theory predicts ethinic 
vartations in the allocation of rewards, and in the anount of discriaination expected. On, the other hand, significant group control over jobs could exist if anority group memers are concentrated in specific "gatekeping" roles in the occupational structure. Examples of engregation in occupational and organizational domans are visuble and have become atereotypess Italian buslders, Jewish tallors, among others.

In some cases minority groups may establish "ethnic domains" and the impact of reward allocation would depend upon the resources avalable for allocation within the anority damain. Reitz (1980) presented data showing that "poorly educated South Europeans earned higher incomes if they worked in settings where the ancestral language was ipoken". Also Hetcher s census dats (1978) showed that socially distant groups with high occupational prestige tend to be occupationally "specialized". These studies suggest that ethnic segregation in jobs does not alway inply the impossibility of inagrants achievingihigh levels of etatus or income, although in our opinion it is very idifficult for ingigrant groups sopecially those with jow levels of education and mall nupber of meabersl to estabjish themselves in high incone or high status positions.

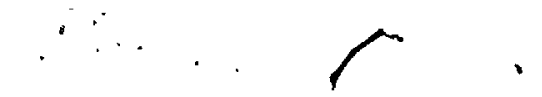

Q Dne condition for the emergence of an econonico enclave is the presence of inmigrents with sufficient capjtal brought frón the origanas country or accumulated through savings. From a dual. lobour arket prespective, inagrants are generally restricted to 
- the sezondary labour napket sector, although imigration laws have riecently encouraged the migration of skilled and professional workers. In general, immigrant workers are viewed as a vulnerablé labour pool,

"destined to the low wage, unstable occupations of the peripheral economy. Past occupational experience and other investaents in human capital count very jittle for these immigrants because, unlike workers in the primary sector, they are hired primarily because of their vulnerability rather than their. skills." (Wilson and Portes, 1980: 300).

In their study about Cuban inmigrants in the United states, Wilson, and Portes argue that there is a third alternative condition added to the primary and secondary dichotomy of the dual labour market theory, which'is an important and. valuable contribution for an explanation of the economic success of some 6 immigrant minorities.

One of the purposes of this study will be to determine whether the Spanish inmigrants in Ottawa tend to be concentrated or dispersed in the occupational structure. There is no evidence of the existence of ethnic enterprises (enclaves) at the present Es a observation, and other sourcesl, we intend to find out whether occupational segregation exists or not lespecially in the case of early immigrantsl and whether these enclaves may be uncovered. 


\section{Iogigrant_Wogen}

Almost all stidies about ethnicity and occupations refer to the ale population. Most of the existing research has treated the experience of imigrant men and immigrant women as essentially the.-sames the experience of women is generally "subsumed urider that of men" (Jacobsen, 1979). The nature of women's and men's situations is different and cannot be treated as if it were similar; imaigrant women occupy a particular and different location in Canadian society than men. It is jmportant to point out that ethnic variations in occupational distribution are not the same for, men and women (Reitz, 1982; Denis, 1981).

Arno polas considers that women are concentrated in the high and low-paying levels of the Canadian labour market because Imigration danission practices since the fifties have encouraged the entry. of these types of workers; the highly educated professional, and the unskilled worker. Many immigrants cannot choose to work where they would like to. Sime analyses the situation of iamigrant women in the garment industry and in dpmestic servicei in her opinion "most immigrants only have a few

years of sehooling. and have language problems. This situation is perpetuated because the women have no exposure to either of the official ifinguages on thi job..." (1979:5)

Boyd. refars to the "doubile burden" of imaigrant woinen who.". are often classified as dependents upon entering Canada when they arke "substantial jabour force contributions, and when they work 
they find themselves in the predominantly female occupations, compared to male immigrants and in blue collar occupations, compared to native-borm women". (1975:406) They are less likely to be found in what are probably ejther the higher status or economically rewarded occupations.

Both Arnopoulos and Boyd have referred to the difficultes experienced by inagrant women, especally if they are married: the husbands are accepted in Canada as independent immigrants, - they are admitted as dependents without any.interest in their qualifications:

Language, education and the chance. to find jobs according to their qualification can be considered anong the problems or masor difficulties for immigrant women in Canada which can explain. their concentration in low status occupations. " The low level of - education and lack of knowledge of French or English have made ther vulnerable to discrimination and exploitation. Without the language they are isolated from the larger society which their husbands and children enter more easily. Learning a new language is esperially difficult for women since they are jes Jikery to join the work force immediately, as men do commission on the Status of Women Report, 1970). It is usual to find them in worksettings where they do not have to speak English or French; and also as homemakers. Their choice of jobs is lifited by their backgrounds. As Johnson puts it: "Such people often preferred to make contact with the labour market through a fallow. 
countryan, even though heraght be oftering a lower wage." $(1982141)$

As we have seen above there is woe "inforation on "job experiences of women in certain ethnic groups in Canada. In Rest, opinion,

"the consistently poor position of any minority group women does not, however preclude the possibility that the pattern of ethnic inequality may not be the same for women as at is for men. Structural factors and socialization patterng may differ between groups, resultingin different patterns of ethnic inequality for woaen." (1981110)

Boyd has suggested that discrianatory practices against imasgrant women are extended and is generally the most important. cause of the pattern of greater inequality imong ionen compired to men.

It 12 anportant to point out the importance of ethnic velues when analysung the economic role of the imaigrant women. There 1. A predisposition to attitudes, values, norms, and behaviour which are part. of the bagage of the innigrant groups brought from their countries and apassed on largely through an inplicit sociabization process". Breeley and McCready in Glazer and Mohynihan, i9751210)

a

The centrality of the family is well known in South European groups.. they are centred on the home for the nost part, and

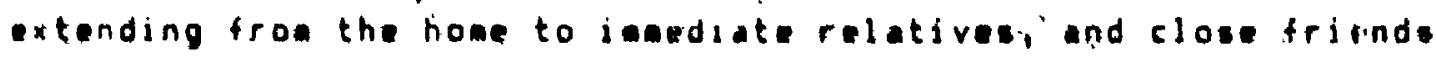
(Chimbos, 1980, Alpalhao and Da-Rosa, 1980). 
is

Sturino, : andyeing the ecgnomic robe of the lanigrant Italian wife, concludes that the primary ophere of inflaence remained pre homé and childreni though she frequently entered the market place as in wage earner, "the nature of her econonic role cannot seriously conflict fanily values" (in Earoli et_d. 1978). Also the author states that her carning power does not thrasten the man's role as provider and chief authority because ine works generaily in low paying occupations, therefore her wape is usualiy seen as a "mere extension of finer role as the facily. shopper".

Alpalhad ind Da Rosa support Sturino's point of view when they refer to Portuguese wives and menis ateltuden towarde wamen's works "Geperatty inen consider that the woesn's placels the home" $(19808130)$.

\section{Integration of Ethnic_orougs _into_the_tider_Soclety}

Conteaporary research on ethnic groups is charecterized by two competing theoretical permpectivess. Aseimilationist and Survivalist. The Ascimalationist position has been dosinant in American sociology, reicforcing also the "melting pot" oodel of immigrant adaptation. Even recent American enpirical research has cupported the thesis of "inevitable assillation" and disappearance of ethnyc ties so that ethnic group nebers echieve upward mobility (Cohen, 1977). 
Survivalism is a position which maintalns that ethnicity has not become less important in prat times; but continues to have. a large impact on social, el romic and political aspects of modern urban life. Contemporary survivadism can be divided into . two categories: a) primordial, which emphasizes the role of the ethnic culture itself and its ego-maintaining and psychologically valuable attributes (Novak, 1973); b) contextual, which focuses on the role of changes in the host society (Yancey et al, 1976; Glazer and Moynihan, 1970, 1975).

According to Weinfield, ethrie survivalism has enjoyed a greater historical dominance in Canada than in the United States. Sociological research in canada "has been influenced by the survivalist assumption which stresses the continued salience of ethnicity, for the English and French, and for all ather ethnic groups in Canada". (1981:82)

in any case, we think it is very important in the study of ethoic groups to consider both the structural and cultural situation of the ethnic group, and on the other hand the situation of the wider society.

As isncer et_al put it: "Ethnic groups have been produced by structural conditions which are intimately linked to the sehanging technology of industrial production and transportation" $(1976: 32)$

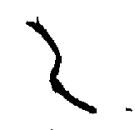




\begin{abstract}
At this time we wll consider the three ajor concepts that will be used in this studyi occupational edjustent, acculturation and,ethnic attachment.
\end{abstract}

The process of integration. of ethnje groups into the wider society refers to full participation in the different dimencions of othe society; that is, integration into social, economic, ciltural and political life. This concept of integration or adaptation is broader than aselablationl Gordon describes integration in terms of a social structure situation which would be apossible to approximate without "the elimination of hard and fast barpiers in the primary group relations and communal il ife of the varjous ethnic "groups of the nation" (1964:246).

Ascinaliation as we have noted earlier is conceived of as a process in which an iethnic group becomes an indistinguishable part of the larger society. The term assiollation implies complete absorption of an ittinic group into the host society to an extent where the ethnic group no ionger has ties with. its tormer culture (Gordon, 1964) Newain, 1973).

The traditional models of ethnse integration arei 1) the anglo conformaty model, 2) the melting pot model, and-3l cultural pl.uralism.

Anglo Eonforaity Mudel, Ianigrants in the United States ang Canade wall confora to the lifestyle and values of the majority 
group, that is, to the Anglo-saxon Protestant ("WASP") group. According to Gordon this has been the most prevalent ideology of assimilation. in America and thas assumption is often bound up with racist attitudes (Nordic racial superiority).

To glve an example we will quote an educator that in 1909 wrote;

"These Southern and Eastern Europeans are of a very different type from the North Europeans who preceded then. 111 lterate, docsle, lacking of self-reluance and Initiative; and not possessing the anglo-teutonic conceptions of law, order and government, their coming has served to dilute tremendously our national stock and to corrupt our civic 1. fe... Everywhere these people tend to settle in groups and to set up here their national manners, customs and observaneis. Dur task is to break up these gróups... to assimilate these people as part of our American race and to implant in their children as far.as can be done the AngloSaxon conception of righteousness, law and order. "Ifubberly cited in Gordon, op.tit.:98)

In Canada, Immigration policies and legislation have shown the extent to which the Eratish orjgan group has served "as the - standard for evaluating the desirability of potential immigrants. -

Unts! recent years the history of immigration policy has been one of restrictive legislation for the purpose of preserving the fundmental character of Canada's population" (kalbach, 1970:10).

Mejt1ng Pot Model: All ethnic groups will contribute to the development of a new group which is an amalgamation of all groups (Newan, 1973). This idea of the melting pot was very popular in the United States before Wortd War I (when most of the immigrants were Northern Europeans), but after Horld War II, it was not very 
popular because the ethnic origin of immigrants was now different, therefore they were not so easily accepted by the dominant group. as potential equals, and consequently more difficult to assianilate lespecially Southern Europeans, Asian ethnic groupsi and other groups of colourl. This model does not make. clear whether all groups will have an equal contribution to the melting pot or whether there is to be a "proportionate , influence depending upon the size, power and strategle location of the various groups" (Gordon,.op.cit:124).

Instead of an impartial melting of the different cultural patterns it nas been more, a transformation of the "new" immigrants into the anglo-saxon mold. In Gordon's apinion there is not a single melting pot in the United States, but a number of. pots or subsocieties: jews, catholics, protestants no matter what the ethnic origan), racial or, quasi-racial groups, and iethnic communities who decide to remain withan the ethnic enclosure.

Cultural-Pluralism: This model of adaptation has gained considerabje popularity since World War II. Accordang to Gordon, it refers to the legitimation of the preservation, of sub-national cummual life and some cultural differentces for the nation's various ethnic groups (opicit:158). This model considers conforaity to the majority group in some areas vital for the integration of the society on one hand, and on the other hand the maintenance of ethnic culture differences. 
The melting pot model does not apply to" the reality! of Enolish Canada because the other groups nave not contributed to the - formation of English Canads as wuch as the dounant angat : saxon group. The other two modelsexplain only partialdy. the stuation of ainority ethnic groups in canadas the angloconforaty model does not explain why othnic comanities stil. exiet in canada, despite a nigh dogree of acculturation. Cultural pluralism, for its part has difficulties explaining the high rate of acculturation and secondary social integration to the nost society, but can describe thellow level of primary social integration of ethnic groups. Canada. in contrast wath other receiving countries, officially recognizes ethnic cultures, and even encourages their iantenance, "Multí

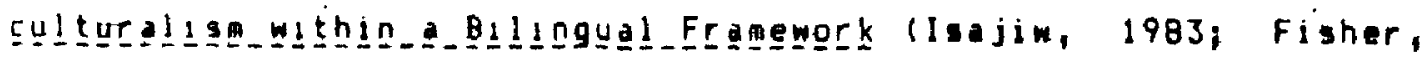
19791.

Both canda and the United states have developed a form of pluralisa, but differently in Canada the recognation of ethnic groups had been established arlier, particularly by the Quebec Act. of 1774, aso the role of governments in regard. to iani-. gration has differed. But Canadian pluralisa cannot be seen as a policy of extending equal opportunities to all ethnic groupsi there has been a pattern pf British dominance as we havo pointed out before, thus "a polscy of non-assimilation makes possible a more rational yet more effective control over potential tensions arlang from culturai differences by containing the deands of the different cultural groups within the bound of edtablibhed - utonomies" (1eajin, 19.75:132). 
Gordon- has suggested a new interpretation of ethnic integrations Stgrugturel Plurglige, which he defines as "an. intergroup relation situation in which ethnic groups of a... society maintain a high degree of structural ceparation but at the same time are highly acculturated to the cultural patterns of the dominant group of the society" 11964). In this model, the ethnic groups keep nost of thesr primary relations witiin their own group, but participate widely in secondary relations with the wider society. In fisher's oplnion, this model seems more applicable to canada than the other three discused above. $(1979: 48)$.

Structural Pluralise or pluralism of "ethose stratification" (Isajiw, 1975), is very sinilar to the "adhesive" model suggasted by Hurh and $\mathrm{ki}$ (1979). To quote theas "adhesive adaptation ay be considered as varlant or sub-type of pluralian. Nevertheless," adhesive adaptation appears to be espocific "analytical category distanguishable from other ideal types of ethnic adaptation..." (1979:191). We will reter to this type of Integration with more detail later a this will be basically the persepective usedin this study.

Gordon has developed a multidimensional approach to ethnic iadaptation that has been iwdely used in sociology. According to him, ethnsc integration is not angle social process but a number of sub-processes or variablis, by conbining cultural. structural and attitudinal factors. His sodel consists of seven 
procosses oi integrationi acculturation, structurai asialJation, aratal assimilation, identificational assialiation, attituoe receptionalossondation, bohaviour receptional assiallation, and civic assiallation (1964).

Gurdon refers to the assialation process of iamigrante and points out the differences between cultural and social.

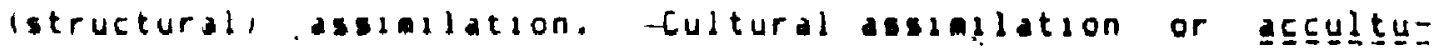
rat $\underline{\underline{1}} \underline{\mathrm{g}}$ occurs when the lamigrants accept the cultural norms, and change their cultural patterns to those of the host society. whilesocial assialiation reters to the large scale entrance into cliques, clubs and institutions of the host society at the oriany group level $(1904171)$. The author suggeste that acculturation ls a necessary but not suificient condition for social asialation, unlike acculturation, gocial assiallation requires the acceptance of the iamigrant group by the dominant group. Gordon also argues that whil acculturation has taken place in the Unitio States, social asimilation has, not. Assialation is otten incomplete ind may or may not move at an equal rate at the cultural and soesal level; the two forms of assiallation are not necessarlly condztioned by one another. An iamigrant can become culturaliy asionilated but structuraliy remain unintegrated. S On the other hand social aseialiation can take place without full cultural asiallation IIsaju, 1975:129).

Acculturation ceems to bethe irst type of asisilation in Gordon teres, to occur and ay continue indetinitaly. Structural. sisilation can occur either simultancously or 
subsequent to acculturation, and when it has occurred, all the other types of assimilation will follow naturally. oThere havg been empirical studies that hive criticized the eapirical appli-

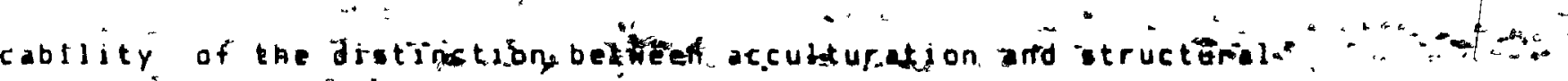

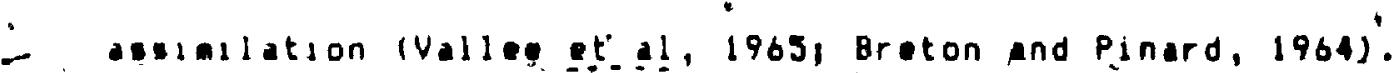

One of the major criticisas that has been made to bordon' mode of integration is that he does not refer to econoaic incorporation despite its crucial iaportance in the Integration process. For the purposes of this study we will andyse the integration of the ottawa Spanish group into the wider society in ferms of two bohavioural sectors or dimensiones cultural and economse. Thus we will focus on the acculturation process and economic incorporation.(in terms of occupational adjustaent). He are not going to take into account priagry socjal integration, political and identificational incorporation because we aseume there is a low degree of these types of integration in the ottawa Spanish comanity. We make this assumption because of the relative recentness of the arrival of imigrants from spain, and according to other scholars, soctal integration, political and identificational incorporation rarely occur in the case of first qeneration lamigrants (Borry and Tishler, 1978 , Gordon, 1964 ).

Econgeic-incogroratign has been considered as the first stage of the imaigrant integration into the host society. The iamigrants wust workl when they find omployment they generilly, 
and

get drawn into the absorbing society economic structure.

Occupation can be a major link between the danigrant and the dominant soclety when they are surrounded by the charter groups, and sust learn new roles, attatudes and values. Occupations can nowever become thaicly enclosed if the immsgrants work in places where most of the other enployees are meabers bf thesr own ethnic group. The initial contacts with the larger society will be wisuly through work, education and racreation.

Economic integration masures the degree to which the ethnic group adopts the occupatyonal pattern of the wider society (Re1t2, 1980al Fisher, 1979, Porter, 1965). The higher the degree to which each ethnsc group is proportionally represented in the verious accupational categories, the higher the degrea of econosic integration. But, as Fisher puts its "the dastribution of each ettinac group among occupational categories is seldom, if ever, proportional. to the group's sizei one alternative is to observe how the group is distributed imgng higher-status and Jumer-status occupational groups" (1979:205). Another indicator of the cconomic position of an ethnic group is the overage total income, compred to the general population fGoldjust and Filchoond, 1974; Restz, 1,980a).

As. we have noted earlaer, documented information about the Spanjsh ethnic group in Canada is very limited therefore we do not know their occupational dastrabution and average tatal. income. The, census does not provide data for these inalgrants 
from Spain, nor for the total Spanish-speaking population in Canada, nor for ottawa. Beciuse of this, we will concentrate more on individual occupational adjustant throughout the sample interviewed in Ottawa.

The goal of the first generation ianserant will encompass his/her adjustanit to thi host socsety's culture and institutions in those areas lof secondary group and institutional contact "which perait him (her) to obtain and keep a job comaensurate with his potentsal and training, to recesve appopriate retraining and education where necessary..." (Gordon, 19641243).

Occupational adjustaent has been treated as a subsection of assiallation or integration studies. Reynolds, in 1935 analyod the process of occupational adjustment of British inagrants in Canada, and the way in which, their readjustaent has been conditioned by "factors in their own background, and by the factors in the canadasituation" (19351157). He considered occupational adjustaent to be basic for the imaigrant s cultural adjustment, and it can be arasured by several indices such al amount of geographical and occupational mobility eince orrival in Canad, the amount of unemployment experienced in canada, the degree of progress or regression as regards skjll-grade, and the immigrant's own attitudes toward canada, and his/her taeling of having gasned or lost as a result of the imaigration. The outhor refers also to the assiallation process in general, and the 
difficulties. encountered such as idealization of the homeland, different valuęs, attitudes of the- natives toward. British Immigrants, initial occupational displacement, among others. He concluded that the British artisan.and the clerk had adjusted well in Canada, contrary to the unskilled labourer who mostly entered in low status occupations and suffered discrimination.

Richmond studied the economic experience of immigrants and ethn1. groups in Canada (1967) focusing on their occupational distribution, occupational status dislocation, standard of living, average total income, length of time seeking to obtain their first employment.

According to Richmond.(1967), more than half of the post-war " amigrants entering Canada experienced a downigrading of their occupational status in the first job thex had for. six months or more. About half of those who fell in status later recovered thesr positions or improved upon it in Canada. This applies fore to the British immigrants than to other ethnic groups. Richmond a) so suggested that amorig the inmigrants expressing more satssfaction with Canada and most inclined to be naturalized were those "who had experienced some jnitial decline in occupational status, but subsequently recovered or inproved upon their former position. The initial traumatic experience of occupational status dislocation appeared to sever the immigrant's attachment to the attitudes and values of his/her former country and compel him/her to adopt Canadian norms of comparison" (1967:187-192). 
Goldlust and Richmond (1974) have also analysed the economic adaptation of imagrants in Toronto. They point out that it is important to take into account the economic experience of the fougrants: the industries and occupations in their homeland, other occupations, and social mobility together with their incomes and expenditures. They defined occupational adjuteent as the indavidual mobility experienced, particularly the oxtent of occupational status diglocation on arrival and degree of subsequent recovery, and saproveant status $(19741198)$.

Various studies have shown that there is often a discrepancy $B$

between antended occupation and the occupation obtained in canada, especially, during the first few years. In iq71 the Departaent of Manpower and Iomigration in a longitusinal itudy about amigrants found that only 59\% entered the intended occupation and after three years in Canada $31 \%$ were otill not in the intended occupation. Goldlust and Richaond showed that on the average lasigrant households in Toronto had experienced a decline of 3.56 Blighen points of occupationai status on arrivali but this was followed by an increase in the blishen score of 5.49 between the first occupation and that at the time of the surver (net upward mobility of 1.46 Blishen points). (1974:193-226)

Intended becupation is a good indicator of the coucational attasnaent and-former occupation of the inasgrant. The change in occupations and educational background ay be acasured by the 
statistics of the intended occupation of the spanish imaigrants to canada. As there are no data available specific to ottawa; the information will be derived from the sample interviewed in our study.

Grygier and Spencer (1975) also carried out a study in Toronto on the economic and social behaviour of the immigrants. They found a high correlation between objective intedtation lbased upon the overt behaviour of immigrants in various spheres, particularly the economic), and the immigrant s current employment. They measured this "objectave" integration by variables such as: lack of ungmployment, lack of ethnjc employment, ability to communicate in English, Canadian friends, among others.

In the United States, Rogg's study on Cuban refugees examined the relation between occupational adjustment and level, of acculturation. He tested whether the Cuban refugee becomes more acculturated as he becomes occupationally adjusted. Rogg confirmed Weinstock's hypothesis that cubans in higher occupations in the United states are acculturating rapidly, but also he found out that perhaps high occupational status of Cubans is obtained because they have acculturated rapidly. In the author's opirion the existence of a strong ethnjc conmunity favourably influences the adjugtment of first generation Cubans although it ay slow their acculturation in the short run $(1974: 130-139)$ 
To measure occupational adjustment Rogg uset objective abservations such as: whether the refugee's occupational level was equal to or higher than his level in his former country. McCurry varied this measurenent in her study of vietnamese refugees in Canada (1979) considering whether the subject's field of occupation was similar or different from his most recent field of work in Vietnan. A report on Ŭgandan refugees (1977) found that a good indication of adjustment was whether or not they were In the work they had hoped to do in Canada (1n McCurry, 1979 ).

Among the subjective observations indicated by Rogg to measure occupational adjustment are: whether or not the refugee bejieved he was using his prjor skills. Mccurry iraried this aspect only taking into account when this occupational value was important to them. Rogg also used a general job satisfaction question, that. is, how content they were with their present occupation in the United States. For the purposes of this.study we will incrude satistaction with current employment becalise we consider it may be an important item related to the level of acculturation of the Spanish immigrants in ottawa.

AcEulturation or cultyreal incorgoration is a process whach includes changes in language use, norms and values, religaous beliefs, social customs, dietary habits, among others, but sone of those aspects are difficult to measure. This is the reason why language shift is generally the iter used most often to operationalize acculturation. In Fisher's opinion "the lack of 
fluency in the language of the wider society is obviously a major barrier for integration. Moreoverjianguage shift ls usually closely correlated with other aspects of cultural incorporation" (i779:218). He considered that the higher the languag a shift, the higher an immagrant is exposed to Canadian culture. In our. specific case we cannot measure language shift using population by Spanish mother tongue and population by spanish spoken at home, because ipanjards and Latin Americans are ineluded'in the same linguistic group. In addition, a special tabulation for Ottawa would be needed.

We will focus then on proficiency in the English language (reading and writing), frequency of use, exposure to canadian mass medja, satasfaction wath life in Canada, and adoption of dietary habits, that have been used in other studies in order to measure acculturation SSengstock, 1978; Rogg, 1974; Grygier, .19751.

Language proficiency is-one of the most amprtant aspects to take into account in the analysis of occupational adjustment, particularly in the case of South Europeans and Chinese Immigrants. They are usually concentrated in low status occupations which do not require high levels of education or well-developed language skills (Reitz, 1980a; Alpahao and Da Rosa, 1980; MeTaggart, 1979).

\footnotetext{
The majority of studies on adaptation of immarants have considered other factors related to this process: education,
} 
length of residence, and stuation in the hust country.

Education play an umportant role in ethnic integration, not only in the acculturation,procest but also in the pconomic dimension. Generally a high degree of economic adaptation and mobility requires extensive education, although in some cases a. ligh educational Jevel does not guarantee upward mobility (Forter, 1905). Grygler (1975) has proved the dependency of occupational adjutent on educational and skild level. On the other hand, Ereton and Plnard (1964), Hurh and Kin (1984). Goldlust and Ruchmond (1974) have also all reported a posituve correlation between "education and acculturation.

Grygier' finding indicated that a high level of education however, did not necessarily lead to a better integration unless lt were combined with other factors such as fair language khowledqe, successful transplanting of skills, foration of fraendships with Canadians (1975). Borheck (1971) in his work about assimilation of Ukranians pointed out the consjstent and strong relationship between education and assiailation, under all conditions. He argued that the single most powerful predictor of both metribds of cohesion (an-group choice and high assialation) is formal education.

Length of residence is another factor related to occupational adjustment and acculturation. This relation has been reported by feynolds (1935), Sacco (1958), Roga (1974), $+$ 
Chiang (1978)1, Grygler (1975), among other seholars, and most of the studies agree on a positive relationship between integration and length of residence in the host society.

in Canada the more likely 1 t was that he had improved his economic status, although the rate of upward mobilitiy was greatest for southern and eastern Europeans, who anjtially had a low entrance status. But, agan education played ari important role In this respect and those with a higher level of education had achieved greater upward socjal mobiljty lir Richmond, 1967a $: 611$.

The economic and political situation of the host country at the immigrant's time of arrival is also related to the inmugrant s integration into the wider society, and evidence of occupational concentration and the situation of the receiving country relationshap is provided by Rejtz (1981), Mctaggart 11979), Richmond (1977), Hall (1973), Porter (1965), Reynolds (1935), among others.

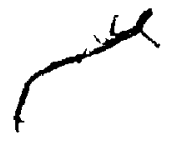

The different industries developing at different historical

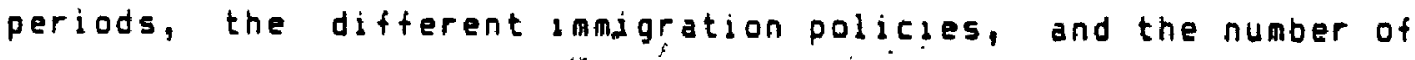
immorants throughout different periods are imgortant to be taken into account as external factors in the andysis' of ethoic integration, and 'specificaliy, economic adaptation lethric conceptration, changes in ethnic, occupations, unemployment experienced). When immigration policies after World. War II 
favoured agriculture and domestic service, one could expect to find a high proportion of women in domestic service for those non-Anglosaxon. ethnic groups with large proportions of immigrants. Kalbach points out that thas holds true for all jmmigrant groups excepts Italiáns and Jews (1979:202).

To conclyde, we will consider this previous research mentioned above in order to develop our own framework of analysis for the study of the Spanish ethnic group in ottawa. We Will. take into account the indicators that in our opinion will beter measure the integration of Spanish immigrants to Canada,. specifically their degree of acculturation and occupational adjustment.

Most of the studies on integration. and adaptation, have mentioned the importance of ethnie ties in the acculturation and occupational. adjustment processes. We consider thas an aspect that "needs to be analysed in more detail for the purposes of our 10 research.

Ethniexattachment will be defined in terms- of "the individual immigrant's subjective identification wath a particular ethnic group and mantenance of initimate sociocultural ties with members of his/her ethnic group" (Greenstone, 1975).. Similarly, Isajiw defines ethnic identity as a "social process by which individuads or groups-subjectively include themselves in a community of their alleged ancestdrs or predecessors, who havea distinct culture" (1983:109). 
Portar and others consider ethnic cohesion to be a serious lapediment to mobility, and an obstruction to economic successi. they consider that "ethnjeity aay impose demands conflicting with those, of the labour market value systen', placing less emphasis on individual economic success; they ay lead. to intensify discrimination at the hands of the ajority groups" (Restz, 1980'0:367).

In the Unitod.states, rancey et_al have ungested that high occupational etatus for aniy ethnic oroups ay be explained by a reduced salience of national ordgins and these groups have avoided discrianation by conforming to the dominant group culture (1976:

Breton in. 1979 suggested that ethnicicohesion fotdd lod to - reinförce inequality because, it interferes with "the free flow of talent, ethnic cultural values, socalization practaces, extended kinship and equegation reduce for the meaber of some ithnic groups the chances for socal mobility (in Vallee, 1981:645).

Ey contrast, other authors argue thit ethnic group cohesion can facilitate upward noblity (Reitz, 1982, Herman, 1978;

4 Chimbos, \$980); Restz: findings in has Toronto study, (1982) demonstrated that Chinese and Southern. Europeans have fajply high incone in relation to education and also have stronger ethnic group ties than, for instance, Northern Europeans who are less. socially distant from the ajority group. 
Tḥere are immigrant minorities which despite their maintenance- of ethnic, ties and less acculturation, and high residential segregation, frequently do better than minoricies. in the mainstream economy. The effects of ethnic cohesion vary depending on characteristics specatic to each group' Igender, number, tine of arrival, etc.). Ethnic groups such as Jews, Italians and Greeks have exercised control over economic opportunities without abandoning ethnsc commusty tjes. In the case of'smaller groups the possibilities for group control may well be more jumited (Reitz, 1980b). This 15 important to bear in mind for the study of a small group of immagrants such as the Spaniards who are not residentially segregated in ottawa, but residentialiy dispersed. Nevertheless we assume that ethnic group ties are maintained by comaunication and are active in linited social situations. As Yancey et_al put it: "Ethnic salience and identification, as.transmitted through the fanily and friends can be maintained, whether they are in the same neighbourhood or not" (1976:399).

Other scholars have referred to the "manupulative" aspect of ethnic identeity (Wallman, 1970) Herman, 4978, Fernández, 1972): Herman has noted that ethric identity can be negative or positive for the individual. In his study of Macedonians in Canada he concludes that ethnicity is a category of identification which is flexible and interchangeable depending on the situation. Although on the macro level Macedonians are clustered in low status occupations, indicating certain constraints caused by 


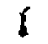

ethncity, on the eicro level ethnicsty seems to have positive effect "by channelling then into an occupation that assures then economic security if not success, and upward social mobility for their children" (1978,81). According to Nagate (1970), etinnic identity is restricted to "private" domain - home, neighbournood, church - whilg canadian values tend to be used more consastently in the "public" domasn, especially in eaployment sutuations. In the sae vesn, Gordon maintass that while structural assimilation takes place in economie, political and educational setuations, religion, family and recreational instatutions encourage ninority pluralisa $(1964: 151)$.
\end{abstract}

In Wallaan's opinion most of the studies have stressed the negative aspects of ethnicity more than the positive ones. She arques that in the sphere of work it can be used depending on the Garcunstances: it may be a postave, neutral or negative value sp the pursust of lndividual or collective gods, "depending on "the "perception of the actiorsy and the cegstrasnts, and

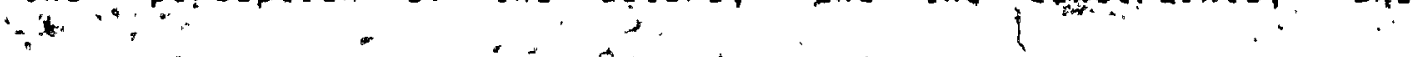
opportuñties in the contex $\vec{t}$ in which they act; ethnicity can be an essential resource, an utter irfievance, or a cripaling $1120111 t y "(1970: 14)$. 11

The work orientation and behaviour of any social. group reflects both the experience, goals and values of that group, and the constrants and opportunitas of a perticular setting (Rogg, 1974; MeCurry, 19791. 
In the context of ajority group theory, ethnic culture is saportant because it may affẹt job qualifications such as education, or skill level, and also, because it aftects acculturation. Rejtz explains how work related values "might vary among ethnic groups, and thus influence their reward allocation; specific cultural values could positively áffect educational attainments, work performance, or the preference for specific occupations leading to a higher level of occupational sewards" $(198217)$

$\mathbf{0}$

Ethnic identaty is. often aantained through faldy socialization, religlous, educational and recreational institutions, ethnic press, among-other elements. The maintenance of ethnic identity needs a lage enough number of "Individuals to sustain certain cultural institutions. Despite the diversity of reqional and social class drfferences among iamigrants of the same, ethnic origin lthay arise frome epecial e historical; geograptical and goctal circubstances), they have onilar patterns of behaviour, at'ititudes and values, reinfored by a common language and nationaljreligion that have both werved to 12 maintain ethnic identity.

Despite the rapid shift togthe English language, ospecially In the United States (Fishman, 1966), investigators.in both Canada and the United States contsnup to study lianguage retention and use, as ipportant indicators of ethnic identiflcation (Heinfield, 1981, Reitz, 1974 ). 
One of "the functions of language accordang to sapir is to bind aroup together and it represents a fundaneptal expreserion of collective identity. 'Thus, language can be considered an amportant variable to the mantenance of ethnic attachoent: In nost conventional sociological literature on adsiallation, language retention 1.s not a key independent variable (Gordon, 1964), but there are other scholars who consider that language retention promotes ethic group cohesion (Lieberson, 1/970, Reitz, 1974).

Joy" $(1972)$ and Lieberson $(1970)$ consider that the manncenance of an ethnic language is not poseiblyuntese there is a sufficaently large number of andividuals speaking that 'Ianguage concentratedin a gaven territory. On the other fiand, Aliderson (1973) argues that a high degree of interaction is observed even when the number of a particular lingustite group is sall. She points out that in a small etrinic group, the members need each other, for socialo contact in the mother tongue, and for assistance.

kinstip and comaunity-resources need to be polfinted qut in relation to job opportunities, specifically, occupational adjustaent and acculturation of 1 migrants. Socjal networks and the ethnac comanity can be considered as a liability because, as Breton (1964) shows, they resnforce ethnic egregation. In adition, Beck et_al (1978) and L1 (1978) concluded.that when Chirese Americans get jobs through relatives, as a consequence they work more often in Chinese businesses and they tend to have Luwer occupational status (cited in Roitz: 1982). 
On the other hand, social networks and ethnic comanity tias nay be considered an asset, specially for ethnic groups such as Jews, Italians, Greeks and Portuguese, who are highly kinor ented, and who place great stress on thi alintenance of these bonds (Goldlust and Rachoond, 1970; Alpaihao and Da Rosa, 1980). is

Social networks are also important as channelefor initaal entrance and for subsequent economic japrovenent. For example, Italians and Jews are concentrated in highly rewarding occupations in the case pof ioronto. In the same way, portuguese Inalgrants in Toronterwith low levels of education are eventually able trólógate jobs which.are "stepplong utones" to more highly - remurierdive positions, through, the auspices of friends and rojatives. Anderson (1974) measured economic success of

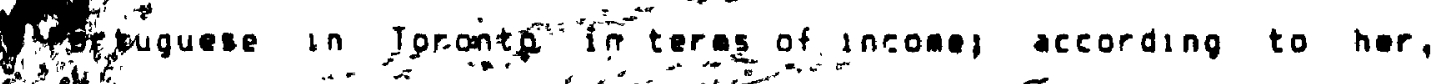

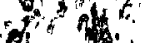
at. Igronto frit teres of lncomel according to her,

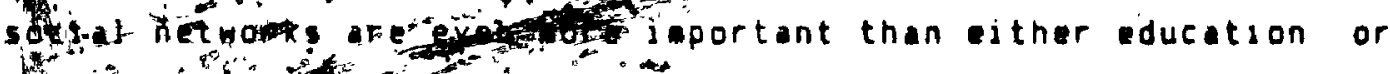

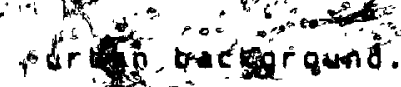
Q

Friends ind relatives ay reter, the inaserant. to "occupational gatekeepers" who can either"place then in low paying jobs with some possibjlity of social mobilaty, or they can "ieter them" to jobs which are "traps" with -ao" possibility for advancement. Anderson (1974) points out the igportance of the

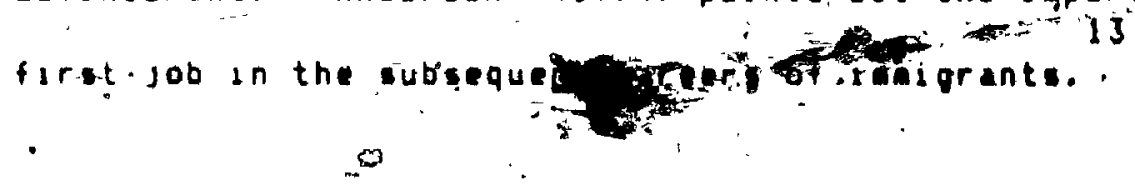

Reynolds (1935) also reters to the importance of friends and relatives in the job-hunting process, porticularly in nelping to find the Hest job. His otudy of krjtion inaigrants in Momtreal 
showed how the absence of friends or contacts could lead to status dislocation of the imaigrant, that 15 , to permanent or temporary work in a different field.

Recently arrived immigrants tend to associate within their ethnic group. The first generation immigrants usually interaci with this enclave in apriaary fashion, and with the rest of the host society in a secondary manner (Breton and Pinard, 1965; Berry and Tishler, 1978). The only exceptions are perhaps the 'highl, skjlled and professional immigrants who develop primary relations with the native born more quickly than the immigrants with a lower educational level (Fisher, 1979). Breton and Pinard focused on the inportance' of social networks in the process of absorption into a socjety, and demónstrated how educational background affected the ability to learni for them "an immigrant with poor educational background, is twice as likely to assocjate within their own group" (1965:78-88).

For our purposes it will be useful to analyse the participation of immigrants in ethnie institutions, in relation to majtenance of ethise ties, level of acculturation and occupational adjustiment of the immigrant.

Breton used an index of comunjty characteristics to predict the degree of commual participation of members of an ethnic group. He measured the "institutional completeness" of an ethnic community by the existence of an ethnic church, ethnic newspaper 
and welfare organization. Ethinac groups who had all of thas level of formal association were more likely to have a large number of members participating in informal interaction with each other (1964:193-205). The more institutions a group has, the more organized it is, the greatér its chance of maintaining its jdentity.

Ethnic, communties with a high level of institutional completeness have, in Ereton's study (1964), a high proportion of persons engaged in manual occupations, and a high proportion of persons who did not have any knowledge of the language of the host society.

It goes beyond this thesis to analyse in depth, the structure. of the. Spanish ethnic community in Ottawa, therefore we will only concentrate on tire frequency of participation of immigrants in the ethnic church, and in other associations existing in the Spanish community.

Sengstock in her study of Chaldeans in Detroit showed that members of ethnic groups who participate in one aspect of ethnic life also are likely to participate in other aspectsi she suggested that there are certain aspects of ethnic life which can be used to predict whether a person wijl or will not participate in these other aspects; these key variables may vary,from one ethnic group to another, for examples a sociar center, a high degree of endogamy, attendance at an ethnic church (1978,64-65) 
Frevious research on the institutional participation of Imatgrants has pointed out the importance of the church. Usually this is the first organization josned by the new arrivalsi churches satisfy not only religlous needs but they also function ds cliaritable organizations either directly or referring the inmigrants to the approprate agencies. They are also sociorecreatiunal centres, they provide a nucleus around which other Imigrant institutions may cluster lReynolds, 1935; Chimbos, 1980: Anuerson, :974; Ereton, 1904; Millet, 1979).

The churties as well as other ethnic associations are places which serve as informal employment exchanges or "job dissemilition centres where news of employment opportunities is passed around" (Anderson, '1974:74). Church festivals or pitenies ds well. as the functions of ethnic clubs are occasions where newcomers get to know others and may inquire and receive. intormation about employment opportunities, job vacancies, ete.

$$
0^{2}
$$

vallee etal have found similaritiza botween ethnic asegciotions and professional associations in promoting the interests of their group, enhancing and protecting its status and autonuiny, by "galing control aver the selection and social$1:$ at 100 of its members to some extent" (1965:66).

Marticipation and support for an ethnic association depends on social pressures. Lt varies depending on the economic and social status, education, generation and carcunstances of migidian of indi.. sual immigrants (Fisher, 1979; Chimbos, 1980 ). 
Generally, wealthy professionals and uniomized innigrants would not have a very high participation rate; high partacipation is more likely to be found among the lower classes: skjlled workers, artisans, service workers, etc. According to some scholars, most of the membership of ethnic associations is middle-aged or old (Palmer, 1975; Fisher, 1979; Isad1w, 1975).

Another aspect of ethnic attachment that we are going to "epinsider is the contact with the homeland, and the jdea of eventual retirn to the homeland. Bottomler considers the taes with the country of origin as an important factor in the development of ethnic identity (1979). The individual's perceptions and behaviour are definitely influenced by these contacts, as well as - the idea of eventually returning home. Usually immigrants have idealized the past and they keep memories of the country of or gin by reading ethnic press, intensifying contacts with family or ethnic friends, or frequent travelling to their countries of origin. 14

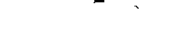

Previous research on Spanigh immigrants in Western Europe has noted the generalized idea of return to the country of origin, mainly among the foreign born generation (Rubso, 1974; Muñoz, 1972). Sacco in his study of Spanish immigratiun in Quebec (19,58) also found a strong desire to return home, which, he felt. might slow down their acculturation process. 
Although the malntenance of ethnic ties, the use of networks of contacts, tend to ansulate immigrants from the wider society, and therefore to jlow down their absorption (Porter, 1965), we do not consider ethnicjty as an anachronism as Porter and others old; we believe that it helps the adjustment of first generation immigrants; it offers a posituve reinforcement and a "degree of self-respect based on familiar cultural understanding" (Bottomley, 1979:78; Gordon, 1964; Jsajuw, 1975). The ethnic... community functions psychologically as a source of group identsty; it acts as a "buffer between the imagrant group and the outside society. TJ some extent this has made it easier for the group to adjust withoutan extremeadisruption of previous dife its members had known." Berry and Tishler, 1978)

Yancy et_al argue that ethic cultures in America are maybe en the result of a selective prockss which consists of a constantly evolving interaction between the nature of the local community, the avalable economic opportunities and the national or religaaus heratage of a partieular group (1976: 397). There are aspects of the originaj heritage that are maintained intact, but others have been. adapted to the corditions of the host society. Isajuw (1975) "considers that the "transplantation" of the old culture (an the first generationl is not a continuation of the old days. The ethmic communty, in summary, is aever created simpli as a replica of the old country elements; it always. progressively reflects the influence of the hast society's conditions. 
Retention of ethnic identity and assialiation ore not necessarjy contradactory processes: they are two processes operating simultaneously (Ësenstadt, 1955, Isaja, 1975), Darroch, 1981). Ethnic organizationalenclosure is not excluded oy aspirations for cultural and socio-econome asiatiaton.

To avosd discrianation or to facilitate the acceptance by the najority group, members of ethnic groups usually experience a loss of some elements of their culture. Sometimes this loss 1 s percelved as a problem. The data presented by breton shows that cortan ethnie groups in toronto "may see their cultural heritage as a fiability, and at that same time they may value their Eulture iot only in itself, but also as an integral part of their personalities" (1981:20).

In. countries of large iamigration with cultural pluralist structures, institutional dispersion or struetural assiailation rarely occurs, manly because of the attitudes of both ajority and winority groups: on one hand the natives have desired the retention of thear own primary group life, without the inclusion of Imagrants; oo the other hand, Imigigants have needed the support of their own ethnic comanity.

- According to Wesnstock (19b3), even the high socio-economic stratus of inmagrants is not necessarily related to. social o assimilation: evidence of this are the cases of certaln ainority groups such as Koreans, Jtaljans, Jews and Greeks in North Hutic. Imaigrant groups ay become highly acculturated into 
the host society way of life because of commant of the language or high occupational status, but not be socially assimilated (Fisher, 1979). As a defence $1 \mathrm{mmigrants}$ maintaln or even enhance their ethnic attachment, and their mode of adaptation will be generally "adhesive" or "accomodative", "that is, they would be acculturated (and to a certain extent socially assumilated), but they would place considerable emphasis on the importance of retalning some aspects of their background llanguage, religion, values, etc.). Fichmond (1974) defines this immlgrant adaptation as "oluralistically integrated type".

The concept of "adhesive adaptation" will be borrowed from Hurh and Kim, and used in this thesis as the partacular mode of 2 adaptation that we assume spanish immigrants are more likely to be experiencing at the present time. According to thas mode of adaptation, theresare, certain aspects of the new cutture and social relations whing memers of the host society which are added on to the immigrant's traditional cultural and social networks, "wathout replacing or modifyang any significant part of the old". In the light of thas conceptual framework we expect the mode of Spanish adaptation will be adhesive, that is, they will be incorporated culturally (acculturated), maybe also to a limited extent, socially, but this incorporation would not replace or weaken any significant aspect of spanish traditional culture and social networks. 
NOIES i Introgduction and_Chagter_onel:

1. Between 1542 and 1792, Spanish expeditions on the Pacific Coast carried out explorations in the process of discovering many straits, islands and bays. The early Spanish presence can be testified by names of places such a5: Carmel Strait, Mount Bodega, Quadra Rocks, among others. Vancouver Island even had a Spanish name at one time: Quadra and Vancouver Island to commemorate the friendship between the Spanish navigator Quadra and Captain George Vancouver. (Ihe_Ganadian_Eamilyy_Iree, 1967:208).

2. An example of the small immigration from Spain las a country of last residencel compared to Fortugal and Greece, even in years considered of high wave immigration:

$\begin{array}{lrrrr} & 1966 & 1967 & 1969 & 1970 \\ \text { Spajn } & 1161 & 1527 & 879 & 808 \\ \text { Portugal } & 9525 & 9500 & 7182 & 7902 \\ \text { Greece } & 7174 & 10650 & 6937 & 6327\end{array}$

Source: Canadian Department of Employment and Immigration, Statistics Section, 1966, 1267, 1969, 1970w

3. In a study on citizenship carried out in Toronto (1978), the Spanish immigrants are mixed with Fortuguese. This alters and makes the analysis of the data very dificult because the proportion is unknown. In this research an estimate of the proportion of immigrants from spain. was established. Portuguese and $5 p a n i s h$ ethnic groups were treated.as homogeneous "until further evidence indacates an error in judgement" (David Neice, Ethngicity_and_Canadian_Citazenghıe, A Metrogolit tan Study, $197 \overline{8}: 521$.

4. Richmond and Verma(1977) give an alternative "global system" modgl of international and internal migration which takes into account the movements within and between industrial and post incustrial sớcieties, as well as movements from less developed to more developed areas. This theory is not going to be discussed in this thesis.

5. Job rewards include status or prestige, income and items related to job security: all of those are considered as job rewards which may or may not be allocated among ethnic groups (Breton et al:1981).

6. This additional hypothesis argues that: "Impigrant workers are not restricted to the secondary labor fiarket. In particular, those inserted into an inajgrant enclave can be empirically distinguished from workers in both the primary and secondary labor market. Entlave workers will share with those in the primary sector a significant economic return to past human capital investments. Such a return will be absent among those in the "open" secondary labor market" 


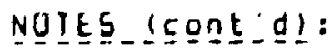

6. (cont d

(Wlison and Portes, 1980:302). Only Bonacich (1978) has referred to imalgrant enterprises from a duat labor market persoective sustaining that imagrant entrepreneurs fulfill "midoleman" functions by exploiting "their own national graup in the interest of larger firms in the center economy". Walson and Portes see tructural reasons for the economic success of certain ethnic minority groups, that is, the existence of advantages for enclave enterprises which those in the open competitive sector do not have (v.l. unorthodox but effective forms of financial and huan capital reserves). Thas enables enclave firma to reproduce (1mperfectly) "some the characteristics of monopolistic control accounting for the success of enterprises in the center conomy" (1980:302).

7. Wheress the Amerigan conststution pounts clearly to unversalsst vision fof free and equal citizens, the canadian Hritish Act of 1867 legitsated group particularisa through explacit recognation of religious and lingustic rights pertasuing to the two "charter groups", the English and the French. Those principles were extended to all immigrant groups comprising the Canadian mosaic. (Weintield, 1981)

8. According to the Ittigration Act of 1976, intented occupation, "...in the case of Landed Inaigrants, a based on' atatement of intention only and there 1. no quarantee that tha intention was realized" IImagration Stetistics, Uttawa: Employment and lonigrationl.

9. If the case of recently arrived imalgrants it appears that there ss no relationship between length of time on their economic position. They have not been resioents long enough to show much occupational mobility. This was proved by Rogg in tier study of Cuban refugeesi their ecionomic positions have improved over time, only when aeasured in terms of possessions $(1974: 120-121)$.

10: . The ethnse community can be a resource for its members. According to Breton at can be a source of relationships for the satisfaction of socio-emotional needsl of assistance in dealing with matters related to job and housingl of services perforaed in the context of a famliar cultural context, "as an organized social unat, it can also provide leadership and promote action to combat discrimination and pursue objectives with regard to culture maintenance, and imagration policies" $(1981,27)$. In his Toronto study, he tocused on the area of job dscrimination and changes in inmigration lans. 
1.1. The situational approach asintalns that there is two way interaction process, according with the denande of particular situations. It provides a nodel whersby, "inaigrants may 'oscillate' between polar types of beitaviour, .... (and) tends to rely heavily on an intensive study of fewer individuals, by neans of participant observation, rather than on the broder sample survey method" (Nagata, 1970:47).

12. It is important to point out that ethnic groups are not homogeneous, and besides the sense of peoplehood and historscal identity that individual share with all the ethnic group, they generally interact with the people of their own elass in that ethnic group. This is what Gordon (1964) has cabled "ethclass". Also Chiabos (1980), Rogo (1974), among others, have referred to this variable" in relation with acculturation and ethnic attachment.

13. Anderson in her study of Portuguese iamigrants in Toronto found that men with high income positions used as gatekepers contacts at trade unions of the construction industry; those who entered construction at the outset had a good ichance of improving their economic position (progressive career), better than the ones who entered in. cleaning and Janitorial jobs (1974:102). Also Li s sudy of ethnic imagrants in Toronto (1979) demonstrated the importance of initial occupational level in stratifying imagrants. In his research, Italians tend to amprove their status relative to those of slavac origin. (p.37). Chiang (1978) showed that the present occupational status of Chinese iturgrante in Montreal was predominantly deterained by "inatial achieved status in Canada... (thus) the relative inoobility of Chinese anagrints was asiny due to the effect of first job rather than education* (p.e 187).

14. In Richmond"s survey of post-war inasorants in Toronto, $-14 x$ of the respondents, conpared with b\% in the rest of canada, expected to aove on to another country or to return to their country of origin. Among these were large proportion of British imigrants who orjginally, entered Canada without intending to become peranent settlers. Other atudies have shown that the return osgration of British inaigrants is largely. wade up of those who are atisfied with their lite in Canada. They return to Britain because this was their original intention, or sometines because of pressing fanily ties andoobligations. Others were dasatisfied (a minority) with their life in Canada and returned basically because of "occupational aladjustaent", especially in the case"of ante aanual workers (Richoond, 1970ai72-73). There aro no data avalable in Canada on the return of Spanssh iamigrants to 5pain. Despita all the efforts made to obtain this information-frow the Spanish Embassy and the Consulate, this was not possible. 
NQIES S Cont'd]:

15. The prevailing rationale of immigrants has always been to secure the means of personal and family mobility, if not for them, for their children. "Mobiljty in a competitike market implies assimilation." (Darroch, 1981:94)

16. Hurh and kim confirmed the existence of "adhesive" adaptation in their study of Korean immigrants adaptation in the United States (1979). They found that strongethnic attachment is not affected by length of residence, socioeconomic status and cultural and $50 \mathrm{cial}$ assimilation levels. Maintenance of ethnic culture is strong irrespective of acculturation rate, educational level or length of residence in the united states. They arque this mode of adaptation would be a transitory stage toward the ideal pluralism or a temporary accomodation. This may. serve as a defence against ethnic segregation, to mitigate the ummigrant's dajly - frustrations, but an the long run to perpetuate ethnic contalnment of some minority groups. Adhesive adaptation 15 a typical phenomenon of first generation immigrants. 


\section{CHAPIEE IWO}

\section{HISIOEICAL_EACKGEOUNO_OF_SPANISH_IMMIGRAIIONI_IHE_HOMELAND \\ - \\ Eefore analysing Spanish amasgration te.canada, we will gave a oriaf description of the socsal, economic and political situation of spasn, and the factor. that appear to have "pushed" the population to enigrate.}

Span hás traditionally been a "sending" country, epecalaby to Latin fimerica, since early in the twentieth century. In the post World War II period, Spanish amagration may properly be defined as a "temporary" one, that 1s; 5 panssh labourers. emigrated in large numbers primarily to Western Europe, specifically to France, West Germany. and 'switzerland. lamigration to the United States and Canada, as we have notide earlier, has been small, compared to that of "guestworkers" in Western Europe. Despite all the differences between the two types of migration, permanent to America and temporary to Western Europe, the workers have contronted sular probleas in their adaptation to the recelving countries. Evidence of this can be found in the jiterature avalable ọn Spanish ianigration to Western Europe: Diaz Plaja (1974); Krane (1974); Rist (1978), Rubio (1974); Rascual (1970) and Mutroz (1972).

The socio-economic and politigal structure of spanish society throughout the different periods of spanish history reviewed below is drawn primarily from the information and data provided by Cairand and Fusa (1970) and Payne (196?). 
We believe that a description of the economic and political situation in Spajn as well as a consideration of the Spanish system of values is important before we begin the analysis of our specific probles, that is, the adaptation of spanjish immigrants, their occupational adjustment and their acculturation in ottawa.

The largest waves of Spanjsh jmmigration in. Canada are to be found in the late $1960^{\circ} \mathrm{s}$. However, in this chapter we will describe the poljtacal and economic situation in spain following the Spanish Civil War (1939), because this period is considered crucial un Spanssh hastory in terms of political and econofic changes which resulted in the mass migration in subsequent years.

Alfonso XIII, the last of the long line of Bourbon monarchs, came to the throne of Spain in 1902, wheri the nation was still staggering from the shock of the loss of its remaining Amerjcan and Asian colonjes to the United. Slates in the Spanish-American war of 1898. The removal of the last vestiges of a "once great emplre" encouraged the growth of liberal ideas that eventually Led to the founding of the Republic (1931-1933). Compared with ot most of the European countries, Spain. was backward, isolated and impoverished; in 1930 spain was at the level of development reached by England and France in the 1860's. (Davis,'1975:2)

At the beginning of the twentieth century, half of the adult population in Spajn was still illiterate gnd the working classes in the towns lived more poorjy than in any other part of Western Europe with the exception of Portugal and Italy. The slow pace 
of economic development and the poor distribution ofe the national income were important factars in generating the antagonsas that provoked the Cjuil War i'n 1936, as well as the Basque and Catalan separatism. Before the Civil War, less than half of the population owned any land at all, but the land-owininge peasantry was nonetheless a capjtal-possessing elass and, "despite its low income was relatively conservative politically" (Payne, 1967:50). In the unterest of owners. of medium and large suze properties, all Republican measures of land reform were abolished by the rebel regume (Nationalist) in the first weeks of the [uvil War. In contrast to the efforts to encourage more industrialization, very little was done by the regime to restructure land-owning and agrarian production until the 1950's; but even after the cavil War, capital investment in agriculture was still not enough to change its structure or increase efficiency.

The relative neglect of the rural econamy was also due to the fact that Generalisimo Franco's government, like most of the twentieth century authorjtariao states, was more attracted "by the glamorous goal of accelerating industrial growth than the prosalc task of organizing peasant agriculture" (Payne:54-55).

When Nationalist"troops entered Madrid in 1939, they found a city semi-starving after nearly three years of Civil. War. From then until he died in 1975, Franco ruled Spain as a Caudillo, "by the grace of God, and as chief of state and head of the governatent... he was a 'constituent dictator', the limits 'of whose powers were self-imposed" (Carrand and Fusi, 1979:5). Francoism 
can be defined as an authoritarian systen structured by political fanilies, the army and the falanga. At the loginning the Falange was a youthomovement whose ain was to create a national Socialist state, a national revolution lnationalization of banks, land reform, recovery of Gibraltar, etc.). Franco took over the party, enlarged at cincluding Carlasts, army officers, cavil servantsi, destroying its jdentity, difuting its social radicalism. According to Carrand and Fusi (1979), the only thing thas conservative bourgeoisie wanted was "to keep the workers in their place using the state and "falangist vertical unions" $(p .25)$.

Spanush society in 1939 was very different "from other Western and European societies. Over half of the population was still Jiving in the countryside in small rural towns. Besides inequalities in income, therie was an acute regional imbalance between a "relatively rich commercialized agriculture and a primitive impoveristied centre: between areas of development and areas of backwardness" (Carrand and Fusi:8). The Catalan peasant in spite of a severe crisis in the thirties, was a prosperous entrepreneur. compared with the Castillian farmer on his arid small farm. Even Andalusia includes both the rich soils of the campina de Cordoba with its agricultural-entrepreneurs and industrial crops and the "tragically poor farms of eastern r. Andalusia where only seasonal emigration to france provides a living wage", (Carrand and Fusi:9). 
In the "western world, rapidurbanization is a sign of industrial growth; in 5pasn this growth, has tended to reinforca the dominace of those regions that had already becone industrialized by 1636 c Catalonia and the Basque provinces. The great exception ls Madrid. It has long been an adainistrative, fanancial and social capital. Thus, there was not only dabalance in agriculture, but also imbalance in industrial development. Spain is a classic case of late industrialization. Even before World war l, its andustrial etructure was weak and dependent on imports and foreign capital and technology. Siailar to. Italy, the north becane industrialized but the south did not. The Spanish late industrial revolution was largely liated to two regionsi Catalonia and the basque provinces. In the late tharties, catalonaa had dévelóped light industries, achine shops, etc., in addition to.ibs traditional cotton and wool industries. Also the basque metaliurgical and ohipping Industries had grown around the iron aines near Bilbao.

,

- The Civil war, as we have seen, provoked an unprecedented economic recession. and. untıl the 1950\%, Nationalist Spain pursued recovery under the influence of fascist models. The two key concepts were autarky, and interventionisá, Proce and wages were controlledi foreign trade and exchange were closely requiated. Spain needed foreagn exchange that coild not be generated by exports and also spain could not raise loans troa the democracies that "ostracised at as a Fascist state" ccarrind o and Fusi $51 i n$. 
Throughout the 1940's Spain was poor: prices were rising faster than wages. After the Civil War, the government developed a wide range of contrel and rationing, but the state bureaucratic personnel could not make thas system of control effective llack of training, low morale, etc.). There was widespread corruption, favouritism and use of influence, and by the early 1940's, a massive black market had developed: "buying was not restricted to consumer necessities but were part of the ordinary functioning of big buszness..." (Payne:57-58).

In the early fifties there was inflation and a severe cris15. In 1957 a tean of technocrats of the Opus Dej introduced a new fconomic policy that emphasized rapid industrial growth. The first step was to open up the country to foreign Investment and foreign trade.

The Stabijization Plan of 1959 was a result of a fundamental review of the regime's econonic policies. This plan marked the end, of twenty years of "pseudo autarky"; although it did not reverse the direction of government policy, it introduced basic alterations (Payre:63).

At the beginning the stabilization Plan had a temporarily depressant effect in sone industries, especially textiles; unemployment rose in 1959 and 1960 . It was in 1959 that Spanish immigration in Europe increased upt to its maximum (Pascual, 1970). The explanation for this increase tan be found in the 
cconoaic situation of spain and in the host societies as well. In Span the deand for local anpower gecreased, aigrations to, urban areas, increased; and the employment situation worsened. A great number of labourers were unemployed, or had lower incomes when overtiae was eliainated there were fewer possibilities for having two or more jous as was the case before. This situation, together with etructural problems on the farms lespecialiy in the south of Spani, moved the government to foster igigation in order to solve the stuation. This led to several trejties and agreements between $5 p a i n$ and other European countries intereated in $5 p a n i s h$ labourers.

The spinsshgovernment which had tried to. stop quigration before, now sulched to promote it and organize it to reduce. social tension. The legal basis and instatutional channels for controling and assisting migration were established in the 1960's. 0fficial treaties with west Germany (1960), france. $11960)$ and Switzerland (1961) were signed. Ealgration was promoted by the government's evidence is the establashent of laws (Ley de bases de la Ordenación básica de la Eajoraciónl and the creation of the Instituto Nacional de Emigración. in 1960.

tespite the boos in the $1960^{\circ}$, agriculture was stil precapitalist, iabourers were only paidosnimun wapes which were much lower than industrial rates (Faynes69i. o a conservative governobnt, supported by "terratenientes" was not capable of carrying out in agrarian reforo (La souchbre, 19641354). The iunction: oi emgration was to reduce unemployent and 
punderemployment in the countrysude and to "soften the ampact of. the' Stabslization Plan on the urban labour force" (Krane,1974); in addition it would help to improve the nation's balance of payments through remittances sent home by immagrants.

$\checkmark$ From the middle of the nimeteenth century whil the 1930's, Spanish immigration was almost exclusively to Latin America; this was a different type of ammigration than the more recent labour magration to Europe. Durang the first decade; after" the Civil War, opportunities for emigration were few, and dad not open up until about 1949, when nearly 42,000 spaniards mígrated, mostly to Venezuela (Venezuelan phase). This lasted until 1955 . For the next few years there was a decline in.enigration until the widening of the European labour markét in.1959-1960 brought about an Inctease.

After world War II the economic advance of some Latin American countraes and the signing of treaties revived the overseas immigration which had ctopped after World.War I, majnly because of the uncreasing selectivity of immigration policies'in Latin American. countries, which were now less interested in admittang farmers or unskilled workers. Preterence for Latin Anerica can easily be explained on both historical and linguistic bases.

The mas difference between overseas and European migration 1s the lack of social and economic integration in the case of 
European migration. In Spanjsh meaking Latin America most of the Spanish innigrants adapted with comparative ease until they became part of the local middle class (see fernández 1984). In Europe the main objective was to save in order to better their situation when they returned "home" to Spain (Krane, 1974 ).

By 1940 the levels of agriculturel productivaty in Spatn were lower than those that had been before the [avil War. Rural poverty in the $1950^{\circ}$ s forced farmers to migrate to the cities. As we have noted, in the nineteenth and early twentieth century, Spaniards, majnly from Galicia and other northerf provinces, had escaped rural isisery by emigrating to Latin Ameraca. This pattern changed in the late $1950^{\circ} \mathrm{s}$ and throughout the $1960^{\circ} \mathrm{s}$; it was the south and centre that became the "reservoir" of labour and the flood went not to Latin America but to other urban centres (Madrid, Barcelona) or to the farms of southera. France. Finally, they became part of the Mediterranean reserve army, a) ong with Greeks, Italians, Turks, etc. an the factories of the Europian community, notably in France and Germany, The exodus began in the 1950's and by the 1960's, Andalusia had lost móre than half a million workers. Without this rural-urban migration, Spain could not have achieved its "industrial. take-off". Emigration abroad shows that the growth of industry and servicies was insufficient to absorb the surplus population carrand and Fusi, 1979). In the $1960^{\circ}$ s as emigration abroad proved, industrial growth could not absorb all the new workers seeking employment. There were problems with the textile and steel 
inoustries and when hign protection was removed in 1901, an acute inancial crisis resulteo.

Thus, eagration abroad ws a chance for social abjlity, the chance to educabe thejr children, to save up to buy a tractor, a business, a house. Hong other goals these were common motlves to leave Spain (Carrand and Fusi; 1979). Ey 1900 it was estinated that 850 , obu spaniards were working in other European countries; in many cases this resulted in a serious arain ot semi-skilled labour, ajways in short supply in spalg IFayne: 1 i.

$$
\text { iy. the } 1970 \text { s the danger of doasnation by multinational }
$$
companies was repedtedly denounced oy tine opposition: "tne resujt ot planning the economy had been to geny spasn the Eapacity for autonosous progress based on native technologyi jpall was paying tor technologicai imports" (Carrand anda Fusi: 55

Hs jpain was industriaizing, ts heavy dependence on Imported iuels was uxposed as a weakness in 1974. It was the" change in the patterns of the exports which indicated the revolution in the economy, by the 1970 sexporte of induitrial gooos became more valuable than jpanish traditional exports oi agricultural products ind minerals; tqurise playeo a larper pot in inancang the take-oit than oranges, toatoes, etc. porhaps the most important proof of the mooernitation of the economy was 
the growth in the 1960 's and 1970 's of the service sector that contracting agricúltural sector that could not find place in a slower growing industrial sector..." (Carrand and Fuss:57). The gap between the two Spains lpoverty and prosperityl had widened with industrialization and population movenents; wealth was increasingly concentrated in the industrial regions of catalona and the Basque provinees, in Madrid and Zaragosa, thus regional disparities in per capita income were still severe lCarrand and Fusi: 65).

The worst years for the economy since the crisis of 1959 (when the stabilization Plan was established) were 1975 and 1976. spain, as elsewhere, suffered very badly from the oil cíisis, but its process of recovery in 1976 was slower and more precarious than the rest of Europe: unemployment, inflation, balance of payment deficit and inequal distribution of income, although salaries and wages had increased.

After 1973 Spanish immigrants began to return to Spaln and in 1975', the doors of Germany and France were cloged to Spanish workers. This return coincided with the nation's heavy economic. burderis and a serious political transition from the frapco dictatorship to a democratic system.

According to Rist (1978), eaigration has been benefitial to Spain, mainly because it reduced unemployment, in addition the i 
foreign exchange income because of the large remittances sent home, has been of some benefit. There are other authors that argue the advantages of enigration. Mendez Toro expressed its adverse consequences in the process toward achieving a balanced economic and social development (in Rist:38). In Diaz Plajas opinion despite the growth of the spanish economy, unemployment exssts; enigration eased the problem in the early stages of development but there is still pegd for planning and for rational and boherent poliejes (1974). Fascual argues that emigration is a consequence of underdevelopment and incapacity to provide work to the Spanish population 11970 .

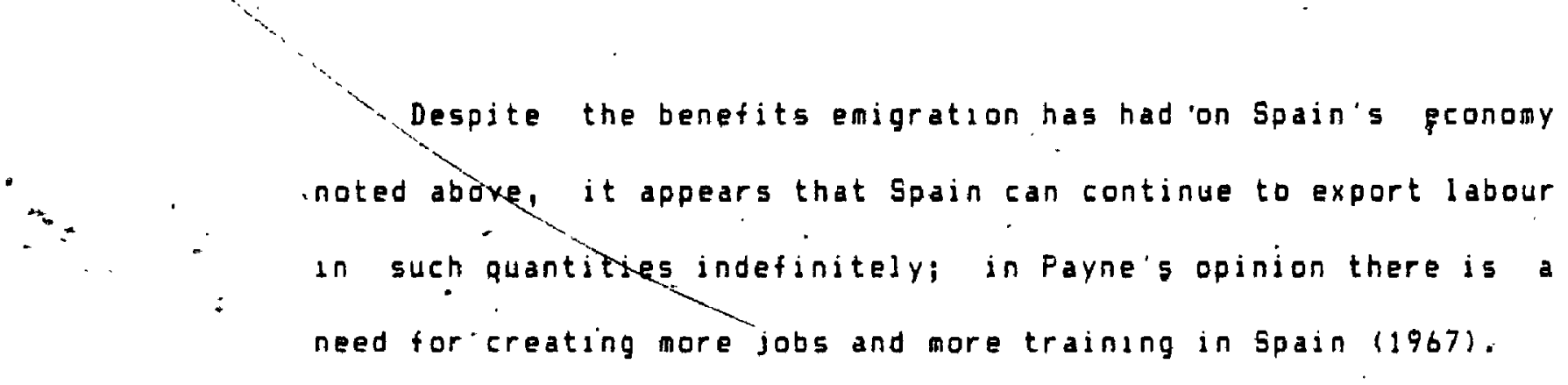

Despite all the gasns made since 1950 , it might be argued that the differences between the Spanish standards and that 'of the rest of Europe. was even greater in 1965 than $i \cdots 1935$. The level of entrepreneurial leadership, though rising, is still not on a par with that of the Common Market countries. Despite all the efforts to speed development, the regime could not devote full attention to helping overcome the weakness of the economy, because 1 t: was based in large measure on the relative oligarchyelements whose position the estabijshent was oesigned to protect (Payne: 72-73). 
In sumary, we can conclude that the major push factors for emigration fron Spain were economic, that $15 ;$ a low standard of living and a lack of jobs. We can also suggest another reason for emigration, the unstable poljtical sjtuation. Polatacal refugees from spain were many and generally they crossed the border into France af the Civil War. The French government needed help to share the economic burden represented by the Spanish refugees; therefore, they made agreements wath North and South American countries such as Brazil, Mexico, Argentina, Cuba, Chile and Canada (Rubio, 1974:24). In 1939, however, only Mexico, Chile and Uruguay agreed to recelve refugees from Span, and from 1936 to 1939 there were about 190,000 emagrants to America, France and other countries.

The traditional role of Europe as a source of settlers in North and South America, Australia, South Africa, etc., "was changed in the decade that followed the establishment of the European Comon Market (Treaty of Rome, 1957). The intraEuropean Common - Market migtations.replaced the loss due to emigration from north and western Europe to other hemspheres, especially in the case of-Italy. As a consequence of the vast concentration of international capital of the countries of northern Europe, additional manpower was needed to facilitate continued economic growth (Rist:7):

Greece, Portugal and spain are moving into a transition phase from a steictly southern country role towards a position 
more like that of the north. Greece becane a member of the. European economic community in January 1984, and Spain and Fortugal are slated to become full members in January 1986.

At this tame we will briefly refer to the system of values dominant in the post-war Spanish society because there 15 a predisposition to attitudes, values and behaviours that are part of the baggage of the amigrant, brought from the country of origin.

The suddenness of modernization in Spasn meant that the older values of a pre-industrlal society persisted in the, era, of rapid capitalist growth. According to Payne (1967) perhaps the most important change in institutional, influence within the Spanish society since the beginning of civil War has been the increased status of the Eatholic church which has a greater prestige not only among the middle class, but to some extent among the lower flass as well. 10 Before the Civil War, Spanish. Catholieism was over-idientified with the upper classes and less with the rural or urbatí lowes classes.

With rapid economic change, the socializing function of the family, and the role of/the father becomes less important. Fanilial authorjtäianis was first rejected by students and young industrial workers, which was perceived as a reflection in their 'parents' attitudes of an authoritarian poljtical system. The classic family of the franco era was traditional and. authoritarian with careful control of the children's activities, 
a control reiniorced oy atconoance de religious scools. weverlliedess most of spaniah adolescents preter to live at home and tamily ties are very strong. mutnoritarianism, traditional atticuoes to status of women, to abortion, ojvorce ano coniraception coexisted. With lie rational values of modern Lapitalism: Tnose traditional vaiues remained rooted in working Lass talites ang at was maniy the working class tamilaes who ,

continued to think that the womert s place was the nome clarrand aliu Fus1, 19791 .

itiere is a ma of secularization and traditionalisa in present-oay Spanisn society. There is a process of change and at the same time of resistance to change and it is the upper asddie ciajs and the rural population trat maintain the old fanily patterns. The secularization process has had a differential o Impact not only among the Jpanjsh social classes but also amoing Lhe various regions of the country. He we noted earlier, agrarian income ano property are more evenly distributed in Latalonia and the basque regions; in addition, religious ineling ano participation are more intense in botn regions than in the - lest ut spain, among the basques much more than the catalans. Dit terent frow testern Europe where reiloious practices are aore . rooted lin the countryside, andustralization has not secularizeo - horthern cities, ano rural andajusia remalns the asot irreliglous region of Spajn, "simply because the Catholic chureh there has been to the mass of the population so much part of the local social establishment" Itarrand and Fusilioil. 
- Tne reijglous element chould not be separated irpá tne cultural element. Inere are noral values, social attitudes and behaviour patterns which though they have become secularized, and have orawn tar away from religious oragins, have their roots in rebigan. Spansaros create a religion adjusted to their personasties; at has developed ansque Spanish form leradford, lyozl. Inis iamilarity with the cnurch as so extended that coven with the iruph or the raght wath the caval War, at dad not criange. Spain 1. a religiously conservative country; neverthesess, accordang to the Foessa kapport (1975-1983), almot all spaniaros detine thenselves as Catnolics, but in practice they do not fallow churcin comandaents or observe ritual practaces. $s$

There are twenty-two percent oi non-practicising catholics compareo to thirty-two percent of practicasing catholics. Hetendance at church on Sundays has diminished (Egeggne_g4, Kevue. d Intormation de I U.J.J.J.

Inojvidualison in. Jpain is etrong;, for Spaniarde the person 1. more important than any instatution or political organization ifistier and Jones, f558). This implies astrust or andifference to Instifutions in general. Selitisnness ind personalisa are aspects ot tho general value of individualisa which have been accepted as being an integral part of the 5panish character structure. In general Spaniards do not teno to join asociationsi membershap. In religious, economic or political organzations perhaps brings people together but does not unify then. As Acevedo puts 1t: "Ther do not know how to cooperate 
witn each other. There is not a set of norms detining long-ter contractual reletions anong a large group of people" (19718131). Thus is especially true in rural comanities.

The strongest expression of the epirit of cooperation in Span 2.s in the lite of the fanily (Eradford,1962157). Hecording to Heevedo, wost of gantield'sypothess about the "anoral famblis" in Italy, is also applicable in Gpan. The major socal unit an jpain as the nuclear fandly, but close socal taes are maintalned with other relatives (1971:123).

During the first decade* of Franco reqine public education was neglected; by the late fifties and early sixties the funds assigneo to education were insufficienty therewas a lack of schools and teachers (La Souchere, 1964,354) and it wase etianed that fifty percent of children of school age did not go to school. Hpparently thist tgure was still higher in gone rurial areas in andilusta. There have been changes in the dast decage to upgrade curriculua and facllities and also to improve the quality of the teachers. In Span education is the ane for upward social mobilaty.

Mose Spaniards encourage formal education for thas children, although very frequently they discourage accondary school because they need their children as workeri in their faras or businesses. Uropouts - are higher among the fomale students than ailes.- But, in general, people in spain place high value 
on education. Thesr support of education "is not based upon the value of intellectual enlightenment but rather because good schooling pays off in.aiding a person to secure a better job" (Acevedo, 1970:70).

Immigrants would judge the host society according to the values brought from their country of oragin. Consequently, very often, they would tend not to accept immediately new cultural values, different styles of life. The process of acculturation will be influenced by the individual's background (demographic, socso-economic, political, etc.).

We have briefly described the socio-economic'and political situation of Spain, in order to determine what factors have fostered. the emigration of Spanjards to Latin America, Western Europe and to a lesser extent to North America. For the purposes of our study, the analysis of social class and regional differences as well as prevalent cultural values and societal networks in the sending country is important, because they predispose the inmigrants to one or another sector of the labour force, and affect, in general, thejr process of adaptation to the host society or receiving country:

On the other hand, it is well known that the situation of the host country has also its impact on the immigration process and adaptation of the imaigrants. As aentioned earlier, Spanish workers have enigrated to Canada and the United States in -small 
16

numoers apparencly, ianigration pobicies in both countrias have been less favourable towards spanisn imagration than to Imaigration from other Northern, Eastern and. Southern European countries, such as britain, Poland or ltaly. Feesons for this lack of attention to thas Southern European country, in our opinion, derive tron the Franco political syatea and reque present in jpain for more than thirty years, and the ralatave lsolation and absence of formal relations between the spanish and Canadian governmelits throughout djfferent hastorical persods. As Sacco puts it: "the Manistry of Catizenship and lanigration did not have enough propaganoa in span compared to that in other countrase" $(1958: 47)$. We have been able to locate only a few references on the Canadion and Spaniuh governments relationship. One of themels found at the time of the Spanish civil war when Canadian Frome Manister Mackenzae king analysed the Spanish situation. Canada was anxious for "stract neutrality" and the government provided surgical, medical and other humanitarian units, only if they were under the control or supervision of the Canadsan Red Cross or some other humanstarian society. However, the debates in the Farliaient did not indicate the general Eanadian working class symathy wath the Spanish Republic ad it could be found in a resolution. passed by the Canadion Trades and Labour Congress in the iall of 1937, and in the considerable number of volunteers enlasted in the ked aray of spain who formed the Mackenzie-paptneau battalion of the xuth International Brigade of the spanish Republican army ithe "Mac-paps"). I3 There were also symathies for the Nationalists especially in Qubbec, 
"stronger than enywhere lse in the Aeericas" ICagada_1n_World Af+1⿴囗十 19371

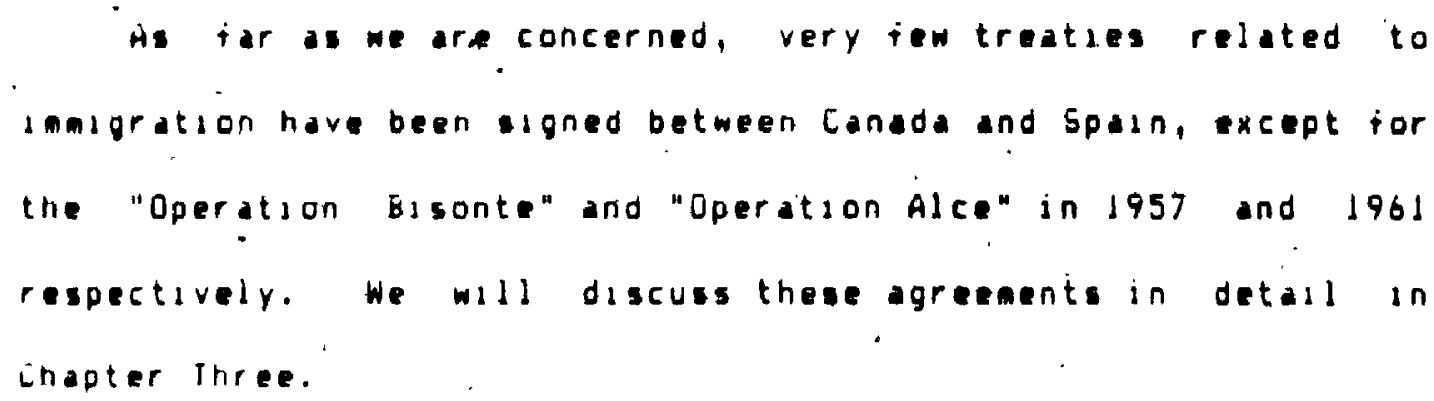

sumarizing, it appeárs that the economic boon and development in the United 5tates and Canada old not attract jpaniardo as wuch as did Western European countries, ainly because, of areater demand for Spanish Iabourers, Imagration policies in those countries, and also the obvious closeness to Spajo which tacilitates easy return to the houeiand. As krane puts it:

"No Longer does overseas igration constitute the main strean of movenent in Europe. The magnetisa of econonic opportunities and political freedoe avaljable in the the West European industrial oemocracies has served to kep Europeans at home. Workers tron less developed countries" have been attracted by the denand of labour in the booming economies or Western Europe." (1974:3)

In this chapter we are not going to conisor the wajor "pull" factors ior the Spanish immagration to Canadabecause this will be analysed in the next chapters, but we can anticlpate fiero that lake other southern European damigrant groups, thev have bein attracted by nigherisalaries, botter woríng and hous:... conostions, the possibilities for a better lifa for their children, and the presence of relatives in canada. 


\section{NOIES:}

1. Ever since the turn of the century the 5panseh povernaent. had publicly recognazed the need for land reiora, but no epeciticesteps were taken to redistribute land. In 1931, in more than half of spain provinces only two percent of the people owned less than five percent of the land Ipuzzo, 1962:5). By September, 1932 (Second Republic), an corarian. reform law was passed, but was one of the most inadequate and least effective eessures of the liberal governaent. aganst traditional powers. In 1935 the Popular Front Coalition probised to epeed up the lind reforas rural payaents were suspended in Extramadura and Andaiusia, preparatory to the resuaption of land retora. Curing 1930 the peasants in western and southern spain conducted thesr own land reiorm. The government ratified the land occupations and tried to help out with sede, tools, trans-" portation and credst iJackson, 1.974, Maar, 1969). In 1930 there were wore than 15 allition peofle on, the land 158 percent of the total populationl ifuzzo,1962161.

2. The Falange was iounded by Jose Antona Pring de Rivera, son of the dictator Miquel Frimo de Rivera 11923-19311. Executed or the Republicans in November 1936 he becane a proto-martyr. The Falange nesther triumphed as a mase party nor becane the axis of one-party state. Jhe reason was that both Franco and the conservative groups thet had supported han in the civil War. dad not want such a party, "they preferred the rule of one man to the rul of a party" iCarrand and Fusi, 1979:25-26).

3. Foreign cepitalisa, has controlled laportant aining and industrial enterprises, e.g. a group of foresgn tananciers from Belgiun, England and canada controlled a number of Catalan hydroelectric power plants.o This international combination wasunown as the Canadiense (Barcelona Fower, Light and Tractronicompany in Toronto) (Puzzo,1962:18).

4. It is semi-secret Catholic lay order founded in 1929, but achuevedeprominace only after the Civil War. "Its goal is to increase the influence of koman Catholacisa in goliticai, econonic and cultural affars, proselytizing anong the elite elements of society. The great majority of its meabers, whether or not they have taken rows of celibacy, carry on secular careers in econonic or cultueal pursuits." Their polstical ldeals are clerical, elitist, authoritaran and technocratic (Fayne, 1.907112i.

3. After 1959, Franco realized that the new post-war qeneration Spantards were interested much ore in a higher standard of living than in politics. He adopted economic four-year planning as in France lpaecal, 1970 ?. 
NUIE

o. Mmcunted to more than elght bidlion dodlars between 19651975 (krane, 1974 ).

7. The exodus to the city and the current of emigration doroad expose the two causes of this massive population transier: "the static agrarian system anc industry inabllity to absorb the excess rural brith rate" lsoucherel, 1904:349). Migration begins in the rural areas and most of all in the regions of the latifunda: Andalusia, Murcaa and Extreindoura.

a. Since the ilvil War, the popudation of Madrid rose from $953, \dot{u} 0 \dot{0}$ in 1930 to $2,376, \overline{3} 34$ in 1963; the population of barcelona had climbed by 500 , vuo.

4. Hermlliegaldo reiers to a considerable number of 5panish political ammigrants who arrived an Quebec at the end of the 1940 s and beginning of the $1950^{\circ}$ s. Those inmigrants were opposed to the Franco regame and organized active small groups in Montreal with-the hope of returning to their nomeland, atter the end of Francossa (1985:6).

10. Eetore the second Reputic (1931-1933), the Churç was a decisive influence in the economac, educatsonal, polatical life of 5pain. Gut with the liberal administration cealition of kepublicans and Socialistsi, there was a demand for the secularization of education, for the separation of the church and state. "It is aportant to apprecsate the extent of the estrangement oi the $5 p a n i s h$ mases iran spanjsh catholicism because fromit dates the advent" and development of anarchism" (Puzzo,1962:7). The arita-cleracal legislation establishod by the fiepublicans itzanat hocked Sparn large population and in 1933 new. elections were called.

11. The status of the women is an umportant. jndicator of development. In spain there were contradictions between the oticial doasnant ideology oi the early days and the denands of the industrial society. The low proportign of wonen in the labour force is aton of backwardness in, Spasn; once women marry, in general, they do not work outside the home unless it is dbsolutely necessary. . The rapid oecline; of domestac service is one of the nost abvious changes in the status ai momen, but stall in the poorest regions it provroes signilfant employment (Carrand and Fusi,1979:85).

12. In the United states the 5panish.quota for inmigration was only 252 per yoar although the Ameralcan Alubassador to 5pain propised to cubit legislation to Conpress to sncrease the imaigration quota o.f Spanish nationals (HIseanićfinerican Fegort, 1955:149,3031. Accordang to the U.S. Census, fron 1421 to 1905 quotas for $5 p a n$, Fortugai and Greece were 250 , 
一正

NQIES_L I CONE_ dI:

ii. cont di

436 and 300 respectively, which are small numbers compared to the assigned quotas for Germany $(25,8) 4)$. Poland 10,488, or Italy 15,645 ) (Berry and Tastier, 1978:174).

13. All though canada had no particular ties with spain, no tradition of historical or emotional attachment, no other country excepting France provided so great a number o: volunteer soldiers in proportion to its population: approximately 1,200 out of 16,vou, vi. The intervention 0 , three totalitarian power 5 , germany, Italy and the Soviet Union, lead to the conclusion that the civil War in spain was a confrontation between fascists and communists, This, in Hoar point of view, was negative for the kipubican pursuit of ad, and "at remains sufficiently alive today to discredit the survivor e of the international force that eventually served in Spain" 1909:6). 
CHAPTER THREE

RECENT SPANISH IMMIGRATION TO CANADA

In the previous chapters we have examined the theoretical framework on immigration and ethnicity, as well as given a brief description of the historical background of Spanish immigration and the homeland prevalent values.

In the first part of this chapter we will refer to the demographic aspects, with specal emphasis on the intended occupation of the Spanish immigrants to Canada; the second part will be a description of the setting, that is, the Spanish ettinit community in oftawa, its organization and general characteristics.

We have already noted in the introduction that the presence uf xilth Eentury spanssh explorers can be found in. Canada in British Columbia, and af Basque fishermen in Newfoundland. But these explorations, especially in the cise of British Columbia, were not followed by permanent settlement. Some spaniards were Included among the people who came to Canada because of the gold - rush; very few, however, were peranent settlers. According to Hoodsworth, by 1907 there were only 131 Spanish in Canada 11909: 25). . It was not until the 1930 's after the Spanish Civil. War that any identifiable number of spaniards came, to canada as permanent imoigráts. 
As we noted earlier, the situation in the host country is very important in helping us to understand the processes of immigration, integration and ethnic preservation. While Immigrátion to Canada has never ceased, it has varied in rolume over tame with two peak periods between, 1901 and 1921, and between 1951 and the present. There have been important changes in federal immigration policies over time which have lead to different mixtures of people entering the country in different periods. Although there has been a strong preference in canada for persons of Eritish grigin and for those from northern and western European countries as immigrants, the decision to open up and populate the agricultural areas of the west. in the early years of the twentieth century led to an influx of southern and eastern European, mostly Foles, Ukransans, and ltalians. Twentyone percent of post-war immigrants were of south European origin, mainly Italians, Greeks; Portuguese and to a lesser extent Spaniards (Hunter, 1981 ).

Sacco's study of the Spaniards in Cariada, specifically those in Quebec, describes the demographic characteristics of this group, covering a ten-year persod, 1946 to 1956. Therefore we will concentrate in this thesis on data relevant to Spanish immigration from 1956 to date.

In 1956 the total Spanish population in Canada was 2,598, of whom $48.4 \%$ settled in the province of Quebec and $24 \%$ in Ontario. The largest number of new imagrants during the ten vear period 
analyseo Dy jacco is to be tound in 1951 and 1950 when they represented $20 \%$ and $22 \%$ respectively of the total $1940-1950$

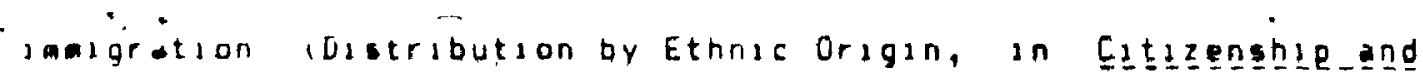
Ima!gratıon keport, $1540-19501$

Houst half of the Spanish unigrants to Canada from 1946 to 1950 were temale and children, who did not enter the labour porce. The male population was concentrated primarily in Industry: 44\% were labourers, and tewer were in agriculture and the service occupations laanly cooks and domesticsi. isacco $1958: 311$.

\begin{abstract}
Hvalable data classjiy langrants accordang to various. criteria: ethnic origin, citizenship, countrty of birth, mother tongue, and country ot last resionce. Unfortunately, there are chanqes or onssions of those criteria from time to. time which nake comparison through the vears difficult. Ethnic origin, tor example, is not considered anywtiere after 1967, with repect to
\end{abstract} intended occupation. Citizenship appears to be the most appropriate criterion. ior analysis, because the cistributaon. wll include not only the imagrans who camedirectly from span but, trom other countries where they were residents between $5 p a 1 n$ ano Canada, masnly in Western Europe and. Latin, America. Gerierally speaking. Spanjsh citizens are in more than $90 \%$ of the cases people born in spaln. 
conpared to other South European groups. Betore 1962, Conadian inmigration policy was "racist" and selective; favourang the entrance of British, Guerican, and Comanwealth countries Imagrants primarsly, and it was not untsl 1967 (point syetea) that there was an enlargement of categoraes of adasesion perasting the entry ot a large number of Europeans, ano innigrants troe other countries. In the restrictionset itage of Canadian iamigration poliey, Spain occupjed second (2nd) rank in terms of selection of ínarants (5acco, 1958).

At this posnt, we are goung to refer to two of the fow inter-governmental agreements between Spain and Canada regarding Imagration: "Operación Bisonte" in 1957 and later "Operación Alce" in $196^{\circ}$.

The "Operacion Eusonte" was sponsoref by the canadian embassy in. Madrad and the Instatuto Nacional oe Emigracion as a test or experiment. Candidates were selecked in the Galicia,. Castilla la Vaeja, Cuenca, Guadalajara, Falencia, Valiadolid and leruel areas: only young couples lless thin 45 years of age could apply, preieraoly wathout children, or at they had thei, the applicant could leave them in spain for could afford to pay for a boarding scisool in Canada isuj or 50 monthly). Other conditions or requirements as a bas of selection
weres good physucal nealth, good behaviour, farm experience and interest in agricultural task. Ine salary for an lamigrant 
couple was between syu and llu antuly and they could sena money to span without any lifitation at any tame. The. Canadian government was fo pay the transportation costs of those applicants without tinancial resources and they could repar it back monthly over a two-year period. The spanish immigrants sent to sette in uuebec could cancel their contract and changed to another tarm it they were not satisiled with working conditions, but these changes were unoer the control ot the canadian inaigration authorities. Atter two or three years there was the possiollity of becoming co-owners ot the farm wath the help of credit.

in an interesting iootnote at the end of thas document the importance of thas expedition is emphasized, the tirst of this type, where each of its members had the "responsibility" related to the "good name of Spain" and its agricultural population, in a new country. Instgucciones sobre eagración al Canada de watrimonios rurales jóvenes destinados a traoujos agrícolas en granjas ae la provincia de Uuebec, March, 1957).
\end{abstract}

Inss lamigration scheme was coordinated in Montreal by the services pour I 1 agrants Catholiques, and a total of 158 arrived in Montreas in two groups during May of 1957.

In 1900 another group ot spanish women cime to canada under the Initiative of the "Instituto Nacional de Easoración", Comision Católica Espazola de Migración. Hs is well known there a and there nas oeen in canada a gemand tor domestic service 
which' is difficult to fill because this work is considered "menial", has low prestige, and is rejected by most native-born Canadians. Therefore there was Canadian interest in immigrants who were willing to enter, domestic service.

This immigration plan from spain was called "Operación Alce". The 5 mall graup of 51 arrived in Montreal where they were distributed to other Canadian cities such as Toronto and ottawa (29). None of them.knew English or French and were assisted in Montreal by the "Centre Social d'aide aux immigrants". They took language courses, cuisine, andinformation about the candian culture with the Sisters of Notre Dame du Bon Conseil.

Generally they came fron Zaragosa, San Sebastián or Bilbajo, Madrid or Palenciai some of them had experience as domestics beforef others used to work as seanstresses, embroiderers or in factories in their country of origin. The salary was-very low, only $\$ 5$ average per week which gave then no possibility to save; on their arrival in Canada they were eligible for a'\$100 lopn to. buy winter elothes or other things they needed. Like many imaigrants they were not accustomed to the cold weather in. Canada; even in the coldest regions of Spain-according bo the them "the snow does not last more than fifteen days.." ILa Presse, Mantreal, Decenber 3, 19.601.

Apparently there was also the demand in Canada frop railway companies, Canadian Pacific Railways and Canadian National 
Railways, for Spanish labourers in 1957, but unfortunately we have not been able to locate the evidence of this demand for Spanish labourers as noted by Sacco in 1958 (p.25).

The total number of Spanish immigrants to Canada during the period 1957-1983 was 19,798 (by citizenship) and 16,897 (by country of last permanent residencel. This compares well with - the total number of landed jmmigrants with Spanish citizenship for the period 1920-1941 (390) and from 1942-1956-(2620). (Sacco 1958: 191.

The flow of immigration in the post world war II period was sensitive to the fluctuations in the demand for labour, and the number entering the country was lowest in the recessionary period of 1959-1962. In the case of the ammigrants coming to canada from Spain (Country of Last. Permanent Residence - CLPR -) in the 1959-1962 period, the total number was 1,735 which is very small compared to 1,372 that emigrated from $5 p a i n$ in 1967 alone; this was the largest number for any one year during the period of time we are considering (1957-1983). From b13 entering the country in 1957, immigration. roṣe to a peak during the late $1960^{\circ}$ s, specifically, 1966, 1967 and 1968. Sinfe 1969, Spanish immigration to canada has been declining and only 271 immigrants from spain entered the country in 1979. This is the sidalest number during the 26 year perfodicovered in this thesis. This steady decline wight be exptained by 11 the restrictions and. changes in Canadian immigration policies (pojnt systea); $2 T^{-}$the: 
end of Franco's dictatorship in Spain and better economic and working conditions in. Spain; and. 3) the facilities made available for the oigration to European. Economic Communaty countries although spain had not yet become a full member of the EEC.

It is interesting to point out that from 1958 to 1971 the proportion of Spanjsh ingigrants coming from Spain las last permanent resjdencel is smaller than the proportion of Spanish immigrants by Citizenship (see Table 3.1). The reason for this. can be found in the re-migration of Spaniards from other countrigs in Europe, especially France, "and in Latin America, especially Argentina and Mexico. This difference as more noticeable during the years $1963(-607), 1964(-449), 1965(-577)$, $1966(-770), 1967(-496), 1968(-316)$.

During the 1970's and early 1980's Spanish citizens and immigrants from Spain entered Canada relatively equally, in the pre-19.72 period. those with Spanish citizenship having a slight edge; from 1972 on those in the CLPR category had a slight edge; there is a slightly larger proportion when considering country of last permanent residence., especially during 1980,1981 and 1983. This suggests that there are now people emigrating to Canada from Spain who have a different nationality thän the Spanas: gtatistics show that half (50z) of this group of jomigrants come primarily fron Iran, European countries such as Britain, and from Latin America, particularly Chile, and since 1983, also fron Peru. 
IABLE_ 3.1

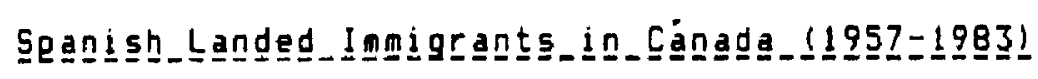

\begin{tabular}{|c|c|c|}
\hline Yegar. & 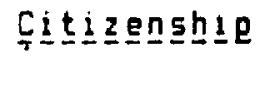 & 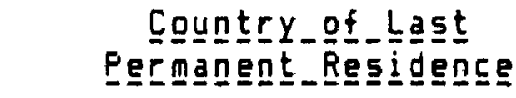 \\
\hline 1957 & 845 & 613 \\
\hline 1958 & 447 & 318 \\
\hline 1959 & 382 & 371 \\
\hline 1960 & 603 & 526 \\
\hline 1961 & 555 & 476 \\
\hline 1962 & 499 & 362 \\
\hline 1963 & 1,043 & 436 \\
\hline 1964 & 1,123 & 674 \\
\hline 1965 & 1,414 & 837 \\
\hline 1966 & 1,931 & 1,161 \\
\hline 1967 & 1,868 & 1,372 \\
\hline 1968 & 1,683 & 1,367 \\
\hline 1969 & 995 & 879 \\
\hline 1970 & 912 & 808 \\
\hline 1971 & 628 & 613 \\
\hline 1972 & 493 & 523 \\
\hline 1973 & $708^{\prime}$ & 688 \\
\hline 1974 & 717 & 727 \\
\hline 1975 & $646^{\circ}$ & 697 \\
\hline 1976 & 548 & 633 \\
\hline 1977 & 332 & 356 \\
\hline 1978 & 269 & 289 \\
\hline 1.979 & 236 & 271 \\
\hline 1980 & 211 & 355 \\
\hline 1981 & 299 & 402 \\
\hline 1982 & 260 & 440 \\
\hline \multirow{2}{*}{1983} & .133 & 323 \\
\hline & $--\cdots$ & $\cdots$ \\
\hline TOTAL & 19,780 & 16,897 \\
\hline
\end{tabular}

Sourtes: Canada, Dept. of Imaigration and Citizenship, Ottawa, $1957-1966$

Canada, Immigration Statistics, Employment and Iamigration, $1967-1983$ 
In Table 3.2 is summarized the citzzenship of ammigrants from Spain for the perjod 1981-1983:

\section{IABLEE_ $3 . ?$.}

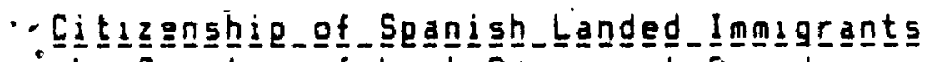
by_Country_of_Last Permanent Kes dence

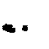

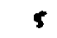

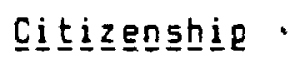

$19 \frac{9}{4}$

$198 \frac{9}{\%}$

$19 \frac{8}{\%}$

1

Spain,

60

50

48

Iran

11

22

30

Europe

13

11

10

.

- Latin America.

$-$

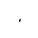

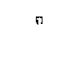

United States

8

9

5

Others

7

6

4

TOTAL

100

(4.0?)

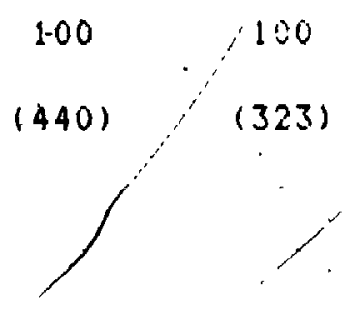

Source: Canada, Immigration statistics, Employment and Immigration, 1981-1983

$\Delta$ 
The distribution of the Spanish immigrants in the various provinces in canada is presented in Table 3.3. This immigrant group has settled mainly in the urban areas of Quebec, Ontario, Bratish columbia and to a jesser extent in Alberta and Manitoba. Up to 1961 , Canadian statistics refer to the settlement of immigrant groups in Canada according to ethrie origin. Sance 1962 the criteraon for the distribution throughout the various provinces has been by Country of Last Permanent Residence. We will assume that the proportion of people coming from Spain as CLPR maintain the same distribution by provinces as those with spanish ethnic origin, sirce we have no evidence to the contrary.

During the late 1950's and $1960^{\circ}$ s, spanish immigrants were. concentrated primarily in Quebec, mainly in the cities of Montreal and Quebec. By the early 1970's there was a tendency to settle more in Ontario, though the difference in numbers between the two provinces is not very significant inever more than 100 ). In the late 1970,5 and early. $1980^{-}$s the concentration in those two provinces varies slightly. The settlement of spanish immigrants in canada is very similar to other southern European groups such as Portyguese and Greeks, and also can be explatned basically because when this concentration started in Ontario and Queber, jt continued when new imaigrants, were sponsored by 'relatives and friends. It may also be attributed to the nonexistence of direct flights from spain to other, provinces, and the. well: publicized better econonic canditions, and general developient in these two regions. 
IAB

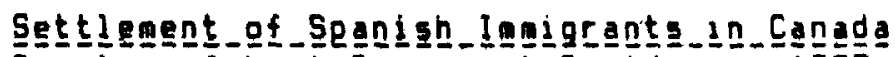

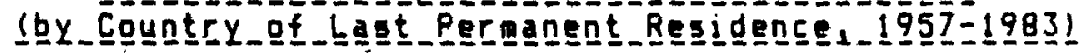

Year Iotad Quebec ontario Oritish Alberta- Mdndtobag

$\begin{array}{rrrrrrr}1957 & 613 & 454 & 110 & .34 & 9 & 2 \\ 1958 & 318 & 180 & 99 & 24 & 8 & 2 \\ 1959 & 371 & 203 & 112 & 31 & 11 & 3 \\ 1960 & 526 & 308 & 149 & 21 & 13 & 2 \\ 1961 & 476 & 274 & 148 & 25 & 15 & 5 \\ 1962 & 362 & 206 & 120 & 11 & 14 & 4 \\ 1963 & 436 & 253 & 132 & 13 & 11 & 2 \\ 1964 & 674 & 406 & 205 & 27 & 13 & 10 \\ 1965 & 837 & 446 & 281 & 48 & 18 & 26 \\ 1966 & 1161 & 642 & 345 & 55 & 31 & 44 \\ 1967 & 1372 & 734 & 459 & 64 & 40 & 52 \\ 1968 & 1367 & 632 & 530 & 37 & 41 & 114 \\ 1969 & 879 & 361 & 384 & 57 & 24 & 22 \\ 1970 & 808 & 323 & 356 & 61 & 26 & 30 \\ 1971 & 613 & 224 & 284 & 58 & 13 & 19 \\ 1972 & 523 & 191 & .229 & 61 & 18 & 11 \\ 1973 & 688 & 244 & 335 & 58 & 27 & 9 \\ 1974 & 727 & 238 & 337 & 82 & 23 & 7 \\ 1975 & 697 & 246 & 254 & 72 & 65 & 29 \\ 1976 & 633 & 280 & 210 & 52 & 59 & 14 \\ 1977 & 356 & 136 & 122 & 42 & 42 & 6 \\ 1978 & 289 & 85 & 115 & 42 & 30 & 6 \\ 1979 & 271 & 127 & 86 & 29 & 20 & - \\ 1980 & 355 & 132 & 106 & 43 & 57 & 7 \\ 1981 & 402 & 184 & 98 & 60 & 43 & 6 \\ 1982 & 440 & 224 & 118 & 48 & 47 & 2 \\ 1983 & 323 & 115 & 136 & 834 & 23 & 6 \\ 1983 & & 136 & 6\end{array}$

Source: Canada, Immigration Statistics, Employment and Inmigration 1967-1983

Canzda, Department of Citizenship ano Immigration, : Ottawa, 1957-1966 


$$
2
$$


IA $\underline{B} \leq E_{-}-\underline{3}: \underline{4}$

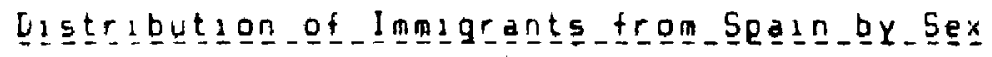

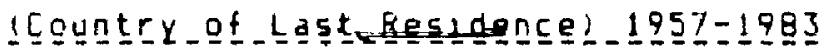

\begin{tabular}{|c|c|c|c|c|c|}
\hline$\underline{r} \underline{\underline{t}} \underline{\underline{P}}$ & Iota! &. & Maje도 & & 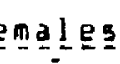 \\
\hline $1957 *^{\circ}$ & 1182 & & 608 & & 514 \\
\hline 1958 & 839 & & 295 & & 344 \\
\hline $1959 *$ & .531 & & 256 & & 275 \\
\hline $1900 *$ & 758 & & 345 & & 412 \\
\hline $1961 *$ & 768 & & 314 & & 454 \\
\hline 1962 & 362 & & 146 & & 216 \\
\hline 1963 & 436 & & 207 & & 229 \\
\hline 1904 & 674 & & 359 & $\because$ & 315 \\
\hline 1965 & 837 & & 455 & & 382 \\
\hline 1960 & 1.161 & & 677 & & 484 \\
\hline 1967 & 1,372 & & $\cdots 796$ & . & 576 \\
\hline 1968 & 1,367 & & 811 & & 556 \\
\hline 1907 & 879 & & 412 & & 467 \\
\hline 1970 & 808 & & 427 & & 381 \\
\hline 1971 & .613 & & 306. & & 307 \\
\hline 1972 & 523 & & 276 & & 247 \\
\hline 1973 & 688 & & 373 & & 315 \\
\hline 1974 & 727 & & 444 & & 283 \\
\hline 1975 & 697 & & 395 & & 302 \\
\hline 1970 & .033 & - & 316 & & 317 \\
\hline 1977 & 356 & & .181 & & 175 \\
\hline 1978. & 289 & & 133 & & 150 \\
\hline 1979 & 271 & & 128 & & 143 \\
\hline 1980 & 355 & & 165 & & 190 \\
\hline 1981 & 402 & & 214 & & 188 \\
\hline 1982 & 440 & & 223 & & 217 \\
\hline 1483 & 323 & & 158 & & 165 \\
\hline
\end{tabular}

*as Ey ethnac origan.

Source: Canada, Immigration Statsstics, Employment and Imalgration, Dt tawa, $1967-1983$

Canada, Lepartment of citizenship and lamigration,

Ottawa, $1957-1960$ 
In relatión to'tas age ano sex distributaon ot iasigranta tros spain that häje entered Canada ance 1957, 1.t sebis not, to be very difterent across the zo-year period analysed in this study. benerally speaking the proportioi or ale and fease labigrante 15 maintalned a lmost invariably $150 \%$ alles and $50 \%$ iemales approxiately,, except for 1966, 1967, 1968 and 1974 when wales outnumber temales; the proportions are 58\%, 59\%, and oli respectively. The cases of tecale superiority are onj during the years 1962 (they account for $59 \%$ ) and 1969 (53\%) nowever, the olfferences are not very large. isee table 3.4 .2

Like other Soutri European immigrants, the majority ot spanish $100 \mathrm{~g}$ grants are in an age group that places them at the Deginning of their most productive period. Adults are mostly in eariv audithood, the number of old people and adalescents is also small. It seems that spanish imagrants tócanada have migrated as atady unit, with some exceptions of advance asgration of the breddwinner of the family, comon during the early $1960 \mathrm{~s}$.

The Jargest proportion of imagrants from span is concentrated in the age groups. $2 u-24,25-29$ and $3 \dot{u}-34$ years oi age. The variation of these proportions through the vears is very saall; in the late fifties and early sixties appoximately 113 correspond, to the 20-24 vear old category, and this percentage increasos durang the perlod 1966 to 1973 . (Table 3.5 ) 
IABLE_ 3.5

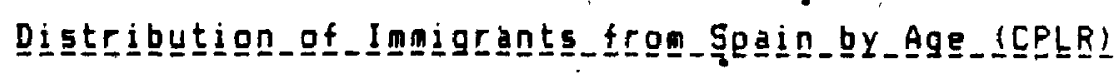

$1957-1983$

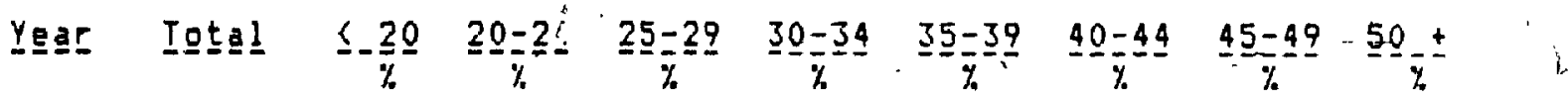

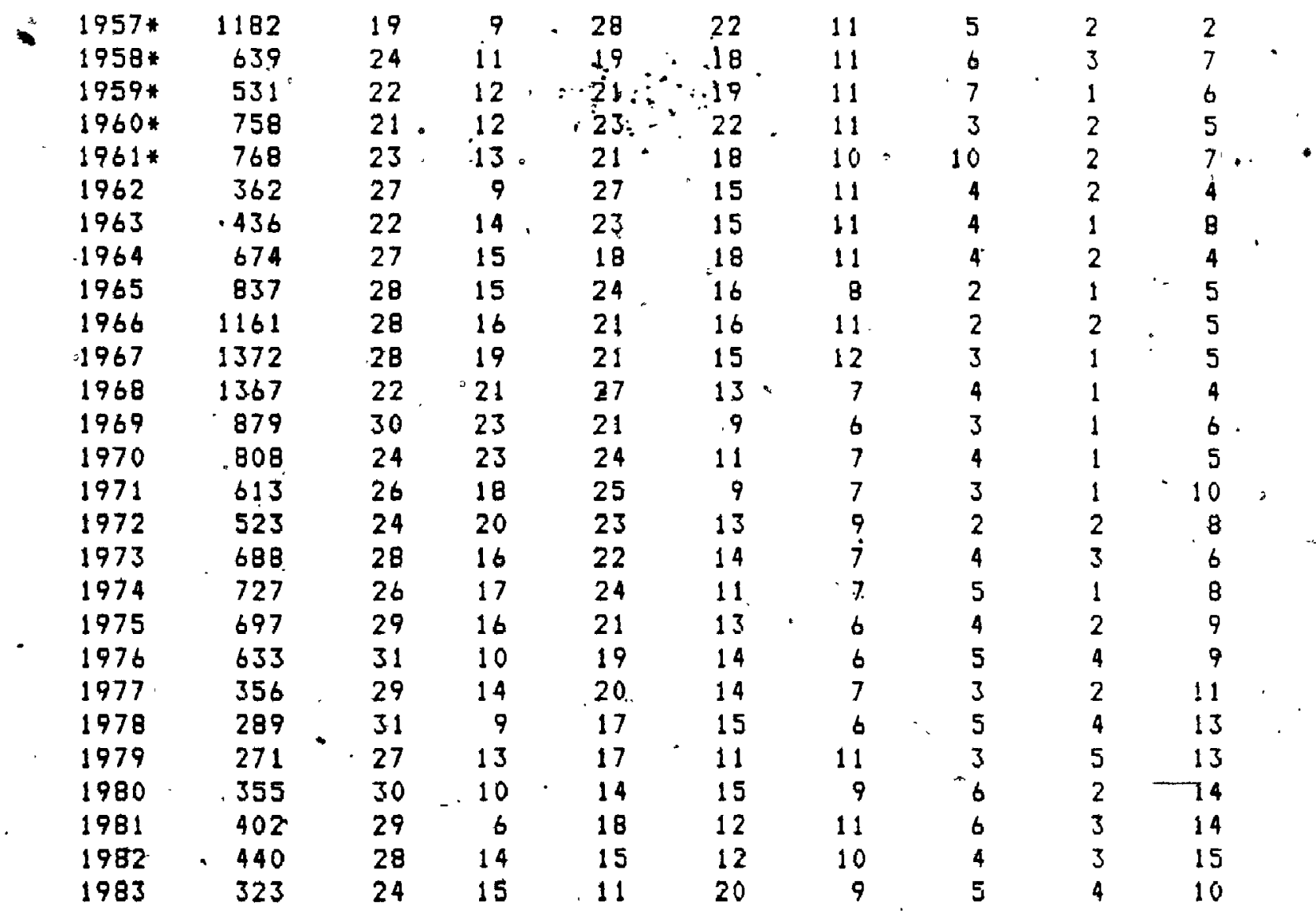

* By ethnac oragin

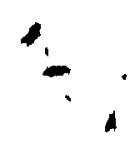

Source: Canada, Immigration Statistics, Emploxment and

Imaigration, 1967-1983

Canada, Department of Citizenship and Inmigration, $1957-1966$ 
During the 1980's, the "less than 20" and "more than 50 years old" population increased, and there was a decrease in the 20 to 34 years of age categories. Immigration from Spain is now virtually "stationary" and it would be likely that. these young and older andividuats are being sponsored or naminated by relatives.

The "intended occupations" of immigrants from spain on their, arriva! in Canada are divaded into two types: (i) manual or blue coliar occupations including all service, primary production and manufacturing workers, and (ii) the non-manual occupations which. include all managerial, professional, clerical, commercial and fanancial occupations. The main trends of the intended occupations of Spanish immigrants to Canada for the period 1957 to 1961 are contained in Table 3.6.

Until 1961 most of the data on intended occupation of landed Immigrants to Canada only considered.the ethnic origin eriterion, but after this year, the information is available by country of last permanent residence. There have also been changes in the. nomination of areas of intended occupation. Up to 1973 the areas machining, product fabrication, assembling and repair, and construction (up to 1962), were grouped as manufacture. In this year (1973) the Service area became more specific. Previously this sector of occupation was divided into cooks, waiters and porters, domestic service and others; the new terminology refers to: pirotective service, food and beverage preparation, lodging, 
IAB

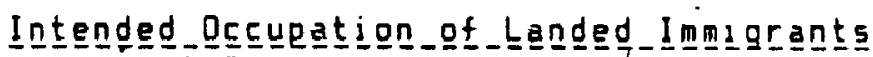

II 95 ? $=1961$ - by Ethni

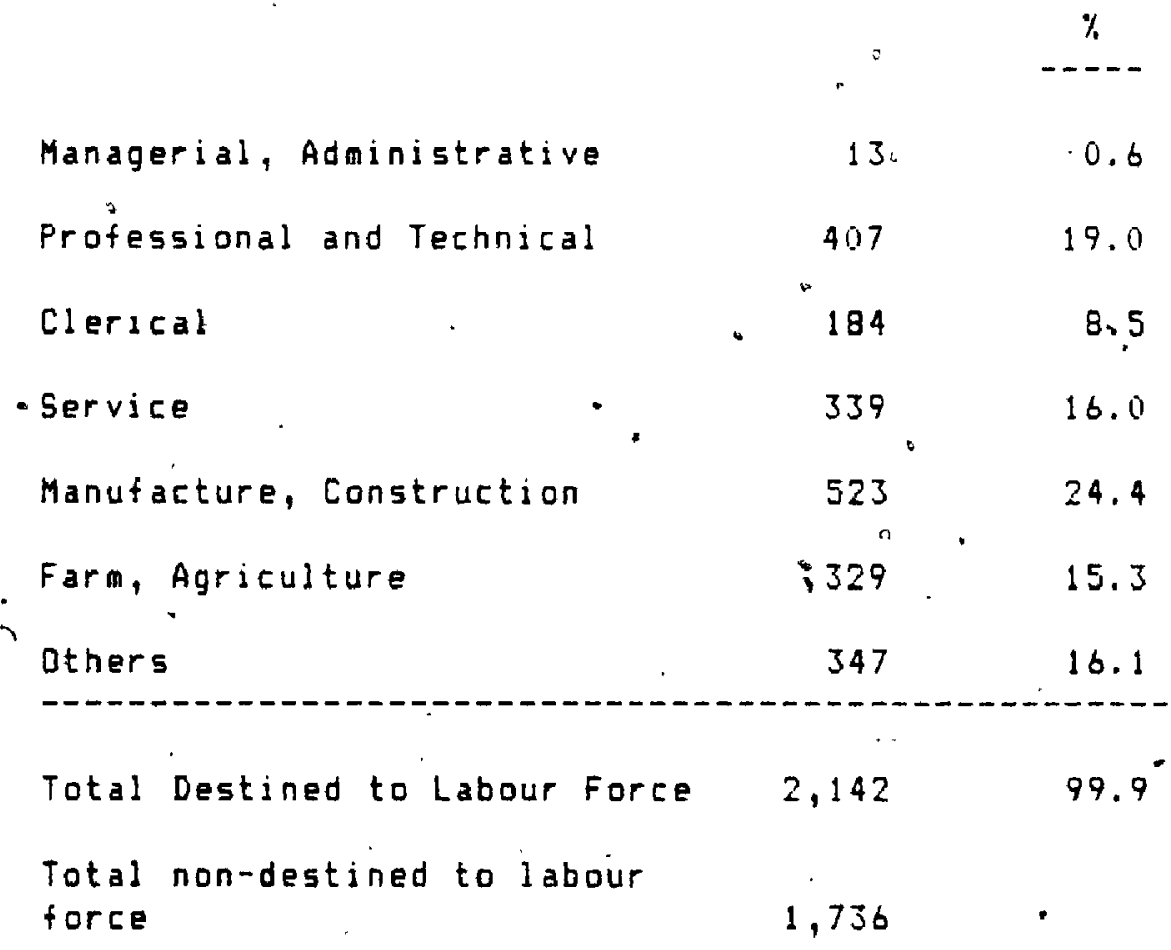

* Spanish ethnic origin also inciudes other immigrants from. Spanish-speaking countries.

Source: Canada, Department of Citizenship and Immigration, Ottawa, 1957-1961 
IAB $\underline{-E}=\mathbf{3}=?$

Preferred_Intended. Oç By Countri of Last_Eermanent Resadence. (1962-1983)

\section{$1962-65 \quad 19666=70 \quad 1971-75 \quad \underline{1976}=80 \quad 1981-83$}

Entrepreneurs, managerial

and administrative

.2

44

94

108

49

Seiences, engineering*

and mathematics; and

other professions

549

266

$\cdot 79$

66

Clerical

114

183

120

59

55

Service

262

355

251.

106

69

Machine and related, product fabricating, assembling and rep.

452

1270

382

171

116

Construction

86

295

212

59

27

Farmers

60

69

25

4

8

- Total destined labour force

(3050)

116321

(741)

(527)

Tot

1082

2537

1616

1163

638

* Notice that this has been the professional and technicaj area where immigrants from Spain have been concentrated throughout the period we are now considering.

Source: Inmigration Statistics, Manpower and Immigration, $1962-1976$

Inmigration Statistics, Employment and Immigration Ottawa, 1977-1983 
and other accomodation, housekepers, servants and related, child care occupations, personal service and others. Another change that should be notgd is related to the professional and tectinical area which before 1974 included all professional and technical occupations in general without any specification. Since 1974 this category has been divided as follows: natural scjences, engineering and mathematics, social sciences and related fields, teaching. and related, religion, medicine and health. The lack of specificity of the earlier periods makes any comparison with Jater data somewhat difficult.

It may be observed that the intended occupation of immigrants from. Spain has been mainly represented in the machining and related, service, profescsional and technical sectors. Evidence of this are the relatively high percentages of the total immigration destined to the labour force found in these areas, especially during the years 1962 to 1975. 
It this occupational astrioution is analyesed in octall. it ar oe ooserved that in the protessiond and technical sector the wost common occupations arei dratongsan, scance technicians. ano otner related to arcnitecture occupations in the service sector are primarliy concentrated in doestic service, wasters and porters in more than $50 \%$ of the inasigats which indicateo service"as their area of intended occupations.

in the machining, tabracating, assembling and repar sectors, apparentiy the preterred occupation that inasiante rom spain intended to have in Canada throughout the perioda analysed ace concentrated in achinists and repalr, and in soller numbers in. tallors and iurriers:

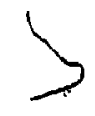

- Honough there is a sajler concentration of ianigrants from Spain in Construction as their intended occupation, it has to be mentioned. that in this specitic sector, the wajority'are skilled crattsmeni - carpenters, oricklayers, ctonemasons, and electricsans, representing aoout $20^{\circ}$ to $30 \%$ of the total inaigrants destined to the construction sector.

In the managerial sector, dangrants from spain are undel represented, although therewas an increase in this sector aiter lijos nanepercent compared to.one percent or less an the other periods or, tiane considerio. 



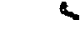

time analysed here; it generally idnstituted 50\% of the total landed immigrants, with the exception of the 1976-1980 period when $69 \%$ of the inmigrants from Spain were destined for the jabour force. This period coincides with the entry of a low proportion of children, elders and women (Table 3.5 ).

It was not possible to compare the intended occupation of Spanish imaigrants with the occupational distribution because. there are no available data on this imigrant group specifically, and it can be obtained only through an expensive special tabulation obtainable fros Statistaes Canada. Hence, we wlll rely on the analyses of the interviews for data on this aspect.

Data available on Spanish'inmigrants in Canada and specifically in the Ottawa-Hull area provided by censuses refer to place of birth, which corresponds to $7.6 \%$ of the total immigrants who came from Spain as country, of: last permanent residence. The distribution of Spaniards by pother tongue will 'not be used because this criterion ineludes all the spanishspeaking innigrant groups in Canada $(70,150)$ by 1981), a sizeable proportion of whom fall outside the scope of our study; the same situation occurs with the classifjcation by ethnic origin.

In the 1981 census, there are 53,540 Spanish ethnit origin immigrants in Canada, concentrated mining in Ontario (47\%) and - Quebec $(28 \%)$. By place of birth the Spanish population is 12,855 which means about $25 \%$ of the total population of Spanish ethnic origin, and $19 \%$ of the immigrants whose mother tongue is Spanish. 
The majority (approximately $57 \%$ ) of inaigrants whese country of burith is Spain entered Canada during the years 1955-1969. Spanish imaigrants by place of birth in 1981 are mainly concentrated in Quebec $\left(5^{\circ}, 705\right)$ and in Ontario $(4,480)$. Of those in Dntario $68 \%$ are located in Toronto $(3,040)$. In the ottawaHull area there are 680 immigrants born in Spain, more than 15 vears old; 570 (84\%) of these,are resident in ottawa.

Although the distribution of Spanish immigrants by sex is generally the same, by any criterion used," there is a little. higher proportion of women in the ottawa areá: $54 \%$ temales and 45\% ales (Census_1981, Statistics Canada). According to the 1981 census, population from Spain is concentrated in the city of otfawa and to a lesser extent in the currounding suburbs of Vanier, Nepean and Gloucester.

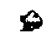

The distribution by age shows a larger number of $5 p a n i \xi h$ imigrants by place of birth in the 35-44 and.45-54 categories in, the case of Canada as a whole and specifically when considering Ontar10.' Dttawa's distribution shows the same tendencies with a large proportion in the less than 15 vears old category.

Qescrigtion_of_the_Setting

As we have discussed in earlier chapters, all ethnic groups may share a need for association based on ancestral culture, but. they may vary in the need to preserve traditional culture. $\therefore 3$ 
We will often refer to the Spanish ethnic group as the "Spanish community". The "Spanjsh immigrants in ottawa are a group of people who share the Spanish culture and language, although they are not concentratedin a limited. territoryi therefore they are not highly "visible".

In the ottawa-Hull' area there is approximately a total of 1,500 Spaniśh immigrants (foreign and native born). Because, of the lack of literature:and accurate statistical information about this immigrant group we will basically use information obtalned through participant observation and informal interviews with leaders and other members of organizations within the Spanish 'communty of ottawa.

Spaniards tend not to have concentrated in certain areas of the city as, for example, Italians and Portuguese appear to have done. During the $1950^{\circ}$ s and $1960^{\circ}$ s thertended to live in the downtown and Vanier area, but presently they are dispersed anong all the Ottawa areas, Kanata, Nepean and Gloucester. There 15 also a.small group in the Quebec sector (Hull, Gatineau, Alymer), but no ethnic organjzations have developed in this area. Apparertiy in the early days some spanish immigrants were temporarily living in Hull because they had a littie knowledge of French which facilitated their adaptation to the naw country.

Evidence gathered in the interviews indicates that on first arrival, the Spanish imajgrants lived with ralatives or friends, 
as other Southern Europeans did (Portuguese and Greeks) (Anderson and Hags, 1976; Chambos, 1980); later they rented houses or apartments, and with time they have bought their, own houses, mainly in the east side of the city, where perhaps the costs were lower. Generally, it appears that they purchase houses as soon as they have saved enough money for the down payment, and despite, the rising cost of housing and interest rates, to own a house is a major preoccupation for them.

Undike the case for other ethnic groups, such as the Portuguese and Italians in ottawa; specific food markets or varlety stores, catering to the special needs of the spanish community have not developed because this réquires a sufficiently large group to serve. Some years ago they had a food store but it "dad not succeed. Thus, spanish products icanned fish, olive 011, asaphran, etc.t are bought in common supermarkets or grocery stores; some Portuguese or Italian food stores supply special needs of Spanish people. The Spanish immigrants livihg in ottawa obtain Spanish goods, books, newspapers and records in Montreal, In a store called "Librerja Española", which caters to the needs of Spanish-speaking people including Latin-Americans.

With respect to special services for assisting the recently arrived, initially there were a few "brokers" to help in -tanslations and flling out forms. This was, offered on an informal basis for the spanish imfigrants, but later those private services were not needed because the government offered them free and in Spanish. 
Presently there are about two bookstores, two travel agencies, three garages, two restaurants IDon Alfonso and Checkers), which offer typical spanssh food, one real estate agency, among other ethnic services for special needs of Spanish $\because$ magrants.

It is anterestang to pount out that some of the services are shared with the Portuguese immigrant group, as is the case of some food stores, bakery, travel agency, bookstore, medacal and religious services.

During the early $1960^{\circ}$ s there were no formal organizations where the 'Spaniards could meet. Apparently the small group living in Ottawa by the $1960^{\prime}$ s used to get together to play soccer (Hispanac Club), usually with Portuguese teams, and from those sport activities emerged the ldea of establishing a center where they could meet, especially for recreational purposes. Until the late 1960's this Centro Español (Spanısh Cultural Centerl did not have its own location. Presently they are planning to bujld new head-quarters.

Before analysing the social structure of the Spanish commuity, we will refer agan to the concept of "institutional completeness" (Breton 1964). Spanish communities in different - Canadian cities and also-in Western Europe have shown a low degree of institutional completeness (Anderson, 1977; Breton, 19641 Muñoz, 19721. Breton, as noted in Chapter 1, deterained 
the level of institutional completeness (high, mediua or low) on the number of churches, welfare organizations, newspapers and periodicals serving the ethnic community.

As we have already noted, culture and the language that it. serves, Fan not be dissociated. Generally, those who care about their cultural heritage aiso care about their ancestral language (Royal Commssion on Bilingualism and (Biculturalism, 1973: 13 ).

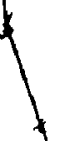

The Spanish language is maintaingd within the fanily and reinforced by the Catholic church. Spanish immigrants have been. concerned with the problems of cultural maintenance among the younger canadian-born generation. They maintasn that if the children were to have a meaningful" exposure to the spanish culture and enjoy its expressions, they will first of all need to know the Spanish languäge. Spanish language maintenance' is viewed as a responsibility of the family. Nevertheless there is a part-time school functioning on saturdays, sponsored partly by the Embasy of Spain. There are about one hundred children attending. this school, also some Latin Americans; some of them enjoy going to the spanish classes; others are coerced into attending. It has to be considered that while other children are

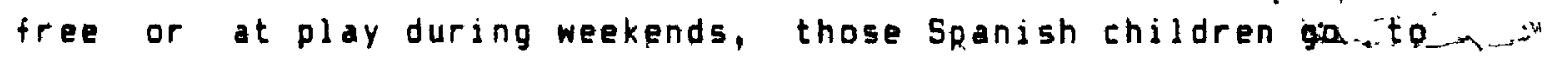
language lessons. There are five teachers lnot all trainedi. and five.courses depending on the children's age. Initially Spanish classes were held in churches, but the school sponsored by the Embassy has been functioning for approximately ten years in. public or separate school locations. 
It is interesting. to point out that although almost all Spanish people in Ottawa tend to speak English (they say it 15 the language of the whole country, whereas french is the language of Quebec), some families send their children to French schools. This group sees an advantage sending their children to those schools because, "they will know three languages instead of two". Another reason mentioned was that through English books, a negative inage (robbers, adventurers) about $5 p a i n$ is transmatted to the children. Hence, they prefer French education as they consider it more objective. Some of the children prefer to say they are Canadian and do not speak about their spanish background "because they feel they are inferior, and will probably be discriminated by natives". This aspect would be interesting for future research on second and third generations of spaniardCanadians.

Religious sêrvices are held in Spanish. on sundays in a French Catholic church (Sainte Famille). Initially these rejigious activities were held in Vanier (White Fathers) and were very important for the adjustment of the recenty-arrived to Ottawa. This institution, in addition to jts manifest reluguous function also has a social function; it provides them with the opportunity to meet each other. In the wintertine people stay and gather in the basement chatting. and drinking coffee, after mass. In the summer the churchgoers stay outside the church $\therefore=$ socializing for more than one hour sometzmes. Ther have been conflicts or rivalries among the members of this organization, 
speciably oetween the "ploneer" participants wno organizea tne . tirst activities ano the "new arravals", aasiv because of leadership and diterences in interests. Evidence or this conflict 15 the olsappearance of a monthly bulletin that was once published.

ine parisn priest ls from velgium and socaks soanish Huently: ne alternates the religlous services with other Latin merican piriests wnen avasjable tron Chile, Colomola, Mexico, ete.', Iand sometimes witn a Frenen priest who also speaks the Ianquage. Inere 1s a parocrial comatter innacujada concepcións which pertorm several activities such as liturgy, catechism, for thé children, visits to sick persons, organize religuous the chiforen, visits to sick persons, organiza religuous testivities ipicnics, raftles, dinners, dances at' Easter,

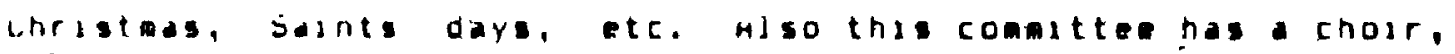
integrated orimarily oy secono generation spaniaros.

ine joanisn religious commonity has about 2000 members not. dl ot whon trequently attend services and other activities. It is Lnteresting to note that approximately $50 \%$ or $60 \%$ of the churcen memoers are trom central and South faerica: This progortion now oeen increasing ovep the last three years because ot the large number ot" refugees trom Nicaragua and El Salvador, a mong other countries, that have been entering the country recentiy. 
lnere is a very close connection between the centro Espanol lthe secular organization or the spansen comaunsty) and the religious association. Ooviously the spanish comaunity. is badl and, wh th very tew foral organizations, therefore the people who attend both of then are laost the samonesf but it should be pointed out that formal memership in the Centro Español is low, only 4ui of the total Spanish househjlos in ottawa.

In this instance, Latin Aaerican, Fortuguese and ltalian people are included and participate in the membership. Ihese inter-ethnic relations have also been observed in vancouver, Vyetoria IAnderson, 1977, and Toronto IHerrero, 19851.

The spansin are socjable people, theretore clubs and meeting-places play an important part in establishing comanity solidarity and socjal life. Hong the actgvities organized through the Centro Español are sports, dance classes, folkloric events, tia projections, national festivities celebrationsiotc. lt has a monthly bulletin which intorms the communty about tuture events and publishês articles on 'spain, imaigration and otner issues.

Hpart irom anduership i\$120 a vearl, the Embassy sponsors any of the activities that the centro organizes. Tnore is: a very close relationship with the Eabass, which acts as an intermediary of the spanish government, opecifically the Instututo Nacional de Eagración. The Embassy intends tó eét 
the needs of the Spanish immigrants in Canada in a general sense, - that is economic, cultural, recreational, etc. Recently (1982) they have"created a new service calded "Departament'o Laboral" to deal with non-consular activities such as social security, pensions and other labour issues. The aim is to extend those benefits when spanish people return to Spain; and the spanish authorities will recognize and include the tume imaigrants worked in Canada as part of their benefits.

$\Rightarrow$ Other organizations working very closely with the Embassy
are the Departments of Spanish at the Universities of Carleton and attawa. Both of them have theatrical activities and present Spanish plays and performances by anateurs. They, participate actively during the "Spanish Week" organized by the Embassy every year in october.

- According to one of my informants, there is a project of the Spanish Government at Carleton University to improve the level of education of the Spanish immigrants in ottawa, through the Continuing Education Department.

In both universities, carleton and ottawa, there are associations for Hispano-Anerican students organized by the Spanish Departments. Primarily, the members are from Latin. American and other countries; very faw members of the spanish second generation participate in these activities. 

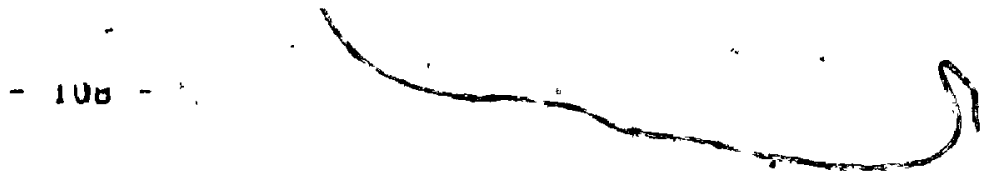

The Spanish Emoassy, together with all the " Spanisn organizations in uttawa, has recently institutionalized the "Spanish week" which attempts to preserve and transat the opanish cultural heritage. This "week" includes conferences, theatre, docuentaries, recitals, dances, etc. it is interestang to note that the attendançe to thiscultural week has been scarce. It seess that the spanish people resident in uttawa are aucn ore interested in recreation than cultural activitie:This can be also contirmed with the low participation rate of the comanaty. when, the center icentroespatoll prosects frles on Sundays. One of the "fundadores" (Fioneers) of the community explained, when interviewedi ",.. attendance at activitios difterent trom recreation ls practically nil... even canadian people are much wore interested in spanssh culture than the. spanish people "themelves".

it would ippear that this situation is due to social ciass oifferences. Hs noted earlier the majority of Spanish imagrants in ottawa do not have a pery high level of educationl wo could say they are priarily working or lower addie class in origin. inere" is a anority oi the comulaty who have a better economic position and have high social prostige accupations iprotessionals, entrepreneurs, etc.l. Often this group has complete1y. olssociated itselt from ltínorking clase compatiots and consequently they do not participate in the aseociations and similar activities. Hence. the cuttural activities soonsored by the Embisey and the universities are of linited interest and the 


\begin{abstract}
large oulk op jpanish jabigrants of working clase origin and those with aiddlectass ockgrouna discociate themselves troa associations and other recreational activities.
\end{abstract}

Ine ethnic media appears to be ot little importance to this - comaunity. Ihere ds one television program in spansoh, sponsored by the government inulticultural policyl in collaboratiorf with the Embasy, the universitas ano ientro Espatol. There is.' no local spanisn newspaper; it is possible, however, to tino newspapers trom the joanish communities in Toronto and Montreal. Newspapers ano agazines prom Spasn can also oe found in uttawa, although there are no specialized Spanish bookstores.

Lontlicts or personalaty, clases, Intrigues, hostiblips and tactionalisa are comon in the jpanish comaufity, not only nere in uttawa out in other cities like vancouver, Toronto and Montreal (see Anderson, 1977: 28-29). These rivalries are, also coman in other south European etnnic groups such as fortuguese, oreeks and Italians iChimbos, J980; Hughes and Kallen,.1974). As we have seen betore, instatutional completenese in the spanish community is very low, and turthermore, internal, fragaentation within the country iapedes the ability of leadership and memoership. to unite and copperate in order to take concerted action in the interests or the etricic category as a wole. 
Criticisas of both the Spanjen Center and the Farochial Comattee are irequently made because of the lack of activities. and also diftusion of the extstent ones. Many of the amigrants are not avaliable or do not want to assune responsibilities connected with organization activities. Ferhaps these people lack experience in arganszational litel perhaps they also lack resources to pay mendersinjp tees, or pernaps, many otners are suspicious or the organizations.

Unlake vancouver anolmontreal, there is a dependence of Latin haerican etnnic groups on the spenish community organi13

zations. Hs anderson notes, "this conviviality is based upon a common language or communacation" $1197 i 121$. There was a project tor a association for Spansoh and Latin American people in Ottawad "the spanish Equass-y was trying to organize it with the cooperation or other Embassies representing Latin Anerican countries in ottawa (Interview with qultural Attache in 1983):

( Compared to other south European groups in ottawa re.g. Itation, fortugesei, the soans in othase comunsty does not have an elaborate structure of fórmal organizations and a lag anount of ethngc services: Also, thin 5panish community does not appear to have a hign degree or residential concentration. Fesidential patterns and institutional completeness reflect the relationshio between an ethnic group and the wader society, it is a masure of secondary social incorporation. Ihis implies trat the ethnic group has to interact with the wader society on a secondary levil. 
betore we go on to the next chapter, nowever, we should point out that it is unlakely that inalgration trom spasn will increase in the near iuture. In the previous chapter the "push" ractors which contributed to tbe pattern of iamagration to canada weri primarily economic. buring the past ten vears it has been known that span would eventually be admatted as a iember of the turopeacommunity. He a result, économic expectations have also - oeen rising, and there has been a real improvement in econome conditions there. Now that Spanzsh memoership has-oecome a reasty, as of january 1,1980 , the impact of the "push" factors will oe minimized:

Uf'interest to us at this tame, as sociologasts, of course, are trie implications tor the spanisn comminity in ottawa ano - ejsewnere in canada as the continuous supply of spanish ingugrants lackens.

In the next chapter, we will see the extent to which this small iamagant group in uttawa has oecome integrated into the

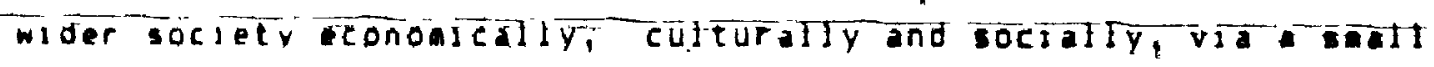
sample ot thirty-one members of this group interviewed in ottawa. 
NQIES:

1. The iret Spaniards to reach forltish Coluabiainay have been the crew of the ship Los Ireskeyes under the comand of Martin hquilar who claimod to have reachod the strat or Juan de Fuca in louj. There were other landfalle of spanish in the 1774; Queen Charlotte lslands, Estevan Poant, and in 1795 Hezeta sighted the mountains of vancouver leland, but his subordinate Juan Francisco bodega y Quadra salled as far as Hlaska claieing possession of only a few parts of the outer lslands for Span. The Spanish kept these explorations quiet intending to follow them up at their leisure. Therefore, it was possible for captain coox in 1778, on has last voyage, to suppose that he was the first on the coast and to begin "the popularization ot the trade in sea-otter pelts whach in the next ten years, was to bring the ships of Gritain and the United states swaraing to the ordtish Columbla coast and destroy the spanish intluence there" (Norris, 1971:2نं31.

In 1780 the Spanish returned to the coast, whin the Englash were trading in the sea-otter peltsi as a consequence there was an expedition under Martinez to establish the elalm. of Spanish sovereignty and permanent settlement at Nootka; in 1789 Eliza re-occupied Nootka and buslt the Fort San Miguel and explored the surrounding waters IV.l. Strat of Georgia, Is a de Langara, or Fosnt Grey, Espinosa and Esperanza inletsl. In 1791 Lon Pedro Alberni planted a vegetable garden at Nootka, "thus becosing the first European agriculturist in Eritish Columbia" (Norrisi204). Eut in 1790. Eritain had strongaction against Spain, and she agreed to surrender her clates to exclusive sovereignty over the territory, and to limat her dominion to discoveries secured by treaties. Thereafter the coast of aritish columbia was equaliy open to the explorations and settleaents of both nations: It was in 1795 when the Spanish decided to withdraw complately and evacuated Nootka, when Guadra and vancouver falled to agree on the lialtations

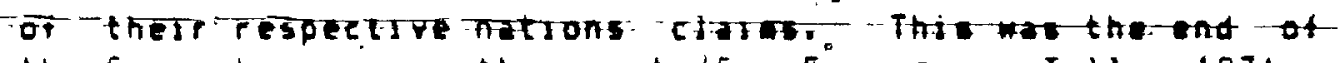
the Spansis power on the coast 15ee Espinosa y Tello, 19711.

2. According to the Citizenship and Inesgration Annual Report 1950-1960, from April 1920 to March 1925 there were only 265 spanish tanagrants in Canada (pp. 31-33).

3. Sometimes data on landed imaigrants by citizenship is not. avaliable as in the case of Intended occupation or Province Distribution. Inerefore the criterion to use will be. the Country of hast permanent kesidence which is also an accurate criteria because spanish imigrants coning from other countries have been relatively rare, especially after 1972. Froa this tiae, again the nueber of Spanish imeigrants by CLPR is larger than by citizenship. We can 


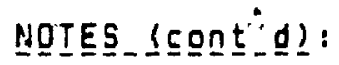

3. (cont'd)

assume that the decrease of emigration to Western European countries from 5pain by the mid $1970^{\circ}$ s could explain the decrease in Spanish eitizens entering Canada from-other countries such as France, Britain, Switerland, "among others. They tend to come. from Span directly.

4. To give an example, in 1955 the proportion of Spanish citizens" that were native "Spaniards" and emigrated to Canada was 96\%. When considering the other criterion, Spain. as Country of Last Permanent Residence, the proportion of native "Spaniards" decreases to $88 \%$ of the total landed $1 \mathrm{mmigrants}$ for that year.

5. By 1981, most of the enigration from Spain was a temporary one, primarily to France $(85 \%)$. According to the 1982 Year Book, only' 14\% of the emigration was of permanent character, mainly to Switzerland (Şzin Year Book, 1982). Approximatejy $56 \%$ of this assisted permanent emigration, by the Instituto Nacional de Emigracion, was from the Galicia province.

6. A relatively high proportion of landed imigrants can be observed in Manitoba for the year 1968, eight per cent of the total. Although we have not been wble to locate the existence of any special governmental agreement, the economic situation for that province was better compared to vears before with an increase of employent in the Construction and Mining industries. There were projects such as "Kettle Rapids Hydro" at Gillan, nickel mining expansion at Thompson. Also there was a shortage of domestic service which was considerably alleviated "partly. due to imoigration from other countries" (Prairie Maneower Reyiew, Nov.-Dec. 1968). For that vear the intended occupations of Spanish immigrants were majnly: Machinists, and other skilled occupations blelectricians, stonemason, woodworkers, etc.l.

7. An ethnic community can be defined as "a group of people who foljow a way of life of patterns of behaviour which mark them out as different from the people of another society, or from other people in the larger society in which they live... they have generally come from the same place, ... or identified with the particular locality where they. now live, They speak the same language, ..." (Fitzpatrick9) $1966: 14)$.

8. In the early days the Centro Español did not have a place where they met on their awn, therefore they used to get together for their neetings at the YMCA, or the White Father shurch in Vanier. At present it is functioning in Vanier as well. 
NOIES_(Cont:d):

9. The ethnic school is not "officially" recognized by the educational authorities in $5 p a i n$ las it is in other cities, e.g. Torontol. They are autonomous and independent from the Embassy, but usually throug,h the Labour Department the school receives donations (money, books, etc.).

10. There are comon celebrations with the French people who attend the Sajnte Fanilie parish, especially at Easter and Christmas. Also Spanish and French share recreational activitues sometimes for fundrasing, such as picnics, dinners, dances, etc.

11. It is interesting to note that the priest in the sainte Fanille parish is actively involved with assistance for refugees from Central and South America Imoney, housing, work, clothes, health and other problems that most of them encounter when first arrive in Canada.)

12. Besides the diplomatic functions of the Embassy, it is verry important to point out that, through its Departamento Laboral it acts as an intermediary of the Instituto Nacjonal de Emigración's plans, such as: distribution of scholarships ("Reina Sofia"f, organization of trips and holidays for youngsters to Spain, grants for primary, secundary, special educatyon and university students, anong others. The scholarships "Reina Sofia" are mainly distrabuted for university ang graduate studies, either in Spain or in other countries (Cahta de España, Madrid, April 1985).

13. In the last years at least three new Spanish-speaking associations have been established: "The Latin American Club", Chilean Club and San Salvador Association. This is evidence of the differences between Spaniards and Latin Americans, which also exist in Vancouver, Montraal and, Toronto (Ariderson, 1977; Herrero,-1985). 


\section{CHAPTER IV -}

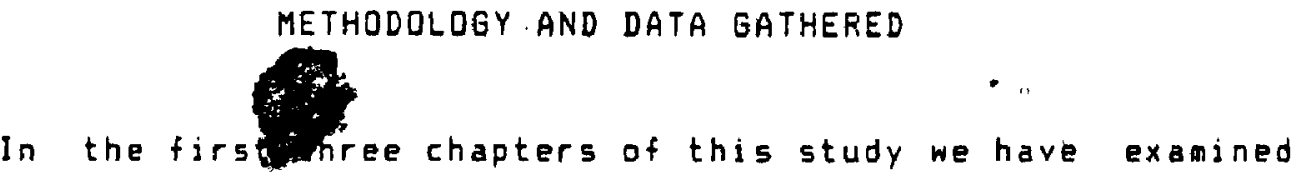

the literature concerned with immigration ${ }_{2}$. general and Immigration to Canada in paricujar. He have also provided a orlef social history of immigration from spain to Canada and other countries.

In the first part of this chapter we are going to describe the methodology used in this study and the problems associated with tracking down members of the ottawa Spanish Inon-Latin American) commusty to be interviewed. In the second part we wll present the major findings of the research and our analysis.

\section{A. Methodology}

A sample of 40 respondents was chosen by means of a random samplè procedure from lists complled from various sources. Only 31 interviews' were completed for several reasons. The final list of approximately 265 Spanish households in Ottawa was abtained by combining information from five different sources: Church.assistance, Spanjsh eultural Center's membership, Bell Canada telephone directory, Spanish Embassy registration, and personal reterrals. There was considerable difficulty getting a complete last of the existing Spanish households in ottawa given the time at our disposal.

0

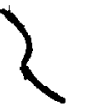


The sample inciuded only Spanish adult immigrants rby country of origin or last permanent residence) who arrived in canada at 14 years of age or over. The choice of this age 15 arbitrary but we can assume that at this age part of their socialization process had been received in spain through the family and the school, and also, after their early teens, people tend to retain even a slight forelgn accent. At any one time only one of the household heads was interviewed, alternatively male and female; they were all between 30 and 60 years of age.

The interviews were sems-structured including mostly openended questions. They generally lasted 45 to 60 minutes each and were carried out in spanish, mainiy at the intervaewee's house or at work, and were all conducted by the researcher.

In general, the selected individuals cooperated with the researcher and were willing to talk about their experiences $1-n$ Canada, sometimes beyond the scope of the inferviewi thex were extremely receptive and showed the thpical courtesy and generosity of the spanish people at home. But in some cases, despite guaranteed anonymity, some of the respondents were suspicious that the information would be passed on to the government, the spanish Embassy or other authorities. This reluctance 
was more comion in the case of older people, with many years in Canada, especially women. In general, men were less reticent to answer the interview questions and the only two who were reluctant to participate claimed they were very busy and also had to work at night.

* Twelve of the original indjujduals selected were substituted by the following name on the list.

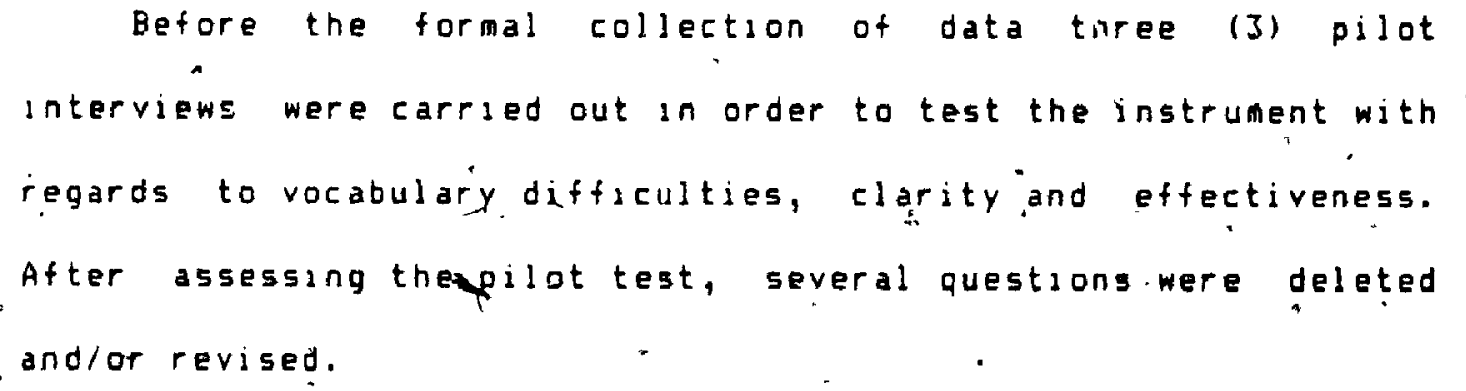
observation lat church, Centro Esparol, informal contacts with menbers of the community), which ls sametimes more reliable than ather methods in studies such as this because some issues we were lonvestigating were brought up more naturally in a non-initerview * situation than in the farmal interviews. Therefore the aterial obtained while interacting with and observing Spaniards in ottawa from 1982 on was also used as supporting evidence.

Another source of information was, informal conversations held. with representatives of the Spanish Government in Canada (Ottawa and Montreal) that $i s$, the Embasy and the Consulate. In 
agdition. insoracion was gathered in other institutions existing in the cttawa spanisn comanity icnurch, club and schooli.

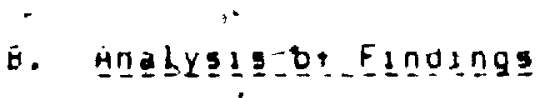

- in our analysis of tindings numerical data have been used - oparingly and only'ina descriptive tashion in contingency tables dispiarang the backgrouno characteristacs of the sample, as neil

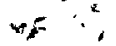

as Its océcuational trajectory, acculturation and ethnic attacnment. beneraldy the results are presentod in percentages and analysed by sex, length ot residence or another variable which at the tiae is considered to be pertinent or important for a better understanding of the results.

sometimes the tindings are reported deseriptively with the use ot direct quotations, excerpts and paraphrase of individual responses, together with idéal typacal respondents profiles as the major lllustrative devices.

lhe results presented here cannot be considered statistically signiticant nor wholly generalizable to a larger popuiation, not only because ot the sall wize"of the sample 1311, but also oecause of the lialations of the listings tron unich the sample was orawn. The" Ehurch list is incoiplete and biased because it does not inciude all the spaniards in ot caw but only church attenders. Telephonedirectories are neither exhastive nor representative listingst there are people who do not last their names; also there are cases where last names aro 
typically Spanish but could yery well be Latin American and some names have been anglicised. In addition, Spanish women who have married non-spanish men are under-represented because their last names have been changed.

Membership in the only Spanash Club in Ottawa the Spanish Cultural Centerl is small, approximately $40 \%$ or less, of all the Spanish familaes; therefore, this list. is also biased because it only includes members. The Embassy list is also incomplete because not all Spanish immigrants in ottawa register their names with this official institution.

I. IMMIGRATION PROCESS

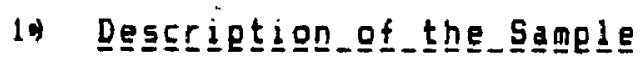

Age_and_5ex: Seventeen (17) males and fourteen (14) fenales were interviewed; the majority were between the ages of 35 and 44 $139 \%$ ), followed by $29 \%$ in the 45 to 54 age group, and $22 \%$ in the 31 to 34 age group. There is a very small representation of the category 55 to 59 years $(9 \%$ ) and none for the older inmigrants (59 years of age and oyer). The sample consisted mainly of longestablished individuals of prime working age.

The main reason for the absence of elderly spanish immigrants in our sample could be foundin the non-inclusion of these individuals in the ajority of the lists from which the sample was orawn. Excepting perhaps for church attendance (which was incomplete because the church does not maintain updated 
records), Spanish elderly people participate in institutions under the name of one of the household heads where they lave. It has to be remembered that there is a tendency for spanssh and Southern Europeap elderly people generally to live with their extended families. The same reasoning can be. applied to the telephane directory 1 ist.

With respect to garital 1 statgus, there are twenty-three (23) subjects, $71 \%$ of the sample, who are presently imarried; two of the respondents are a widow and a widower, and the rest, sêven (7), are single males (23\%). The proportion of single males is high considering their ages, mainly between 35 and 44 years old. The majority of these single men have been in Canada for 17 years or more, but they may have been too much involved with their careers and economic future, or perhaps for some of them the chances of marriage are reduced, especially within their own ethnic group because of the slightly larger number of male inmigrants from spain compared to females.

Among the people who are married or were in the past, seven met and married their spouses here in Canada, two were marraed in France, and fifteen were already married in spain. It is interesting to point out that

nine were married to a person of non-spanish origin such as: French-Canadian (3), EnglishCanfadiart (1), Northern European (2), Portuguese (1), and Latin Ametican (2). This seventy percent endogany confirms other studfes concerning the South Europeans tendency to marry inside 
their ethnic gnoup (Reitz, 1980:120; Chimbos, 1980:111).

.

Most of - the respondents came directly from Spain (65\%), others (35\%) had previous or interinediate imigration experiences in other countries.such as France, England, Mexico,. Venezuela, Colombia and the United states. We will see later how this previous magration positively affects the acculturation of, the subjectr.

The average number. of children per household frum a total of 54 children is 2.3, most of them were born in canada $(60 \%)$; the rest in spain and to a lesser extent in Latin Amerjca lMexico and Colombial. The total second generation in this sample is 46 children and the total of third generation spanish-canadian individuals is 8 children. There are three individuals in the samplè who came to Canada with thejr parents, .. Ehey ore considered second generation for the purposes of our study, but they were included because they came to canada when at least 14 years of age and they received most of their early socialization outside of Canada (in Spain or another intermediate country).

Approximately $50 \%$ of the spanish immigrants in our study were born or lived in regions where agriculture is the basic econony such as Galicia; Andalusia and Castilla la-Vieja. Five individuals came from Castilla la Nueva, specifically Madrid; the rapital. The third.highest proportion corresponds to Asturias and Cantabria (4) which are mainly dependent on livestock and 
aro. minerals such as coal. Two of the total saple came from Catalonia, well known for its industrial development, and only very few of them. came from the Extremadura, Aragon and Basque regions. "Overall, the Goanish immigrants included. IA tbesanple thad a ruralebackground.

TABLE $4=1$

1

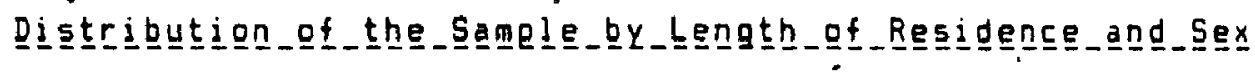

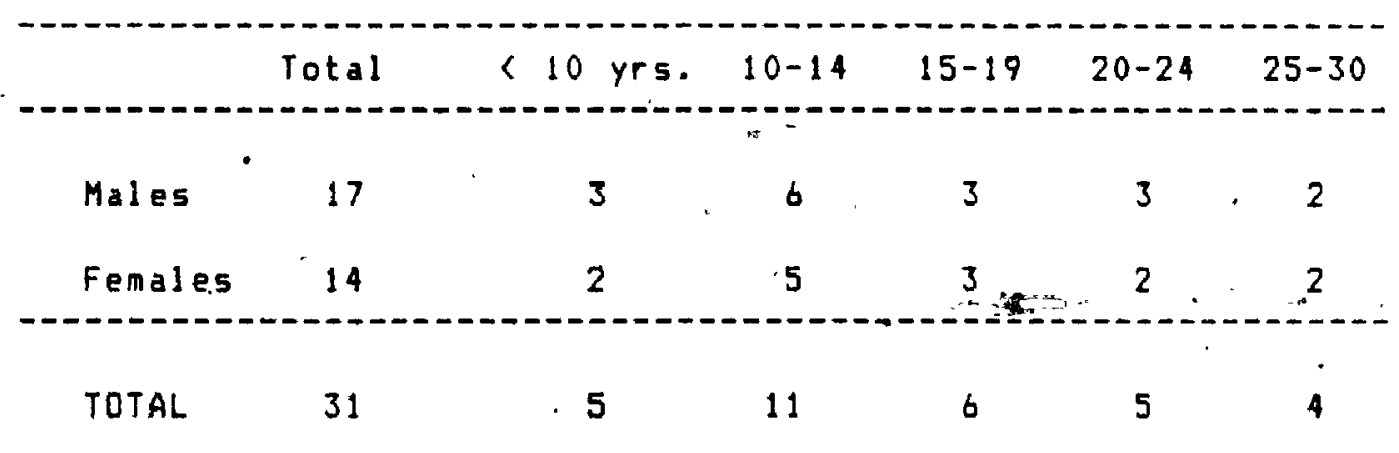

Source: Guada, Sample Survey, Spanish Comminity, Ot.tawa 1985

The average_age at which the respondents came to canada is 26 years ojd. Only five of the individuals in the sample came after 35 years of age to Canada. On the other hand, the average nugber_of_years living in Canada was fifteen years, which means they came mostly in the early seventies. (1970-1975), although as we have noted in earlier chapters, the peak waves of Spanish imnigration to Canada;were during 1967-1969 (see Table 3.1 ). This may be explained by the preference of Spanish inigrants at first to settle in Quebec rather than Dntarjo (see Table 3.3 ). 
Ottawa was the destingtign chosen by $16 \%$, followed by $13 \%$ who settled in Montreal on their arrival for a very short time, not more than three months, with the exception of one respondent who lived there for, twelve years. Smaller proportions lless than 10\%) have lived previously in Toronto, Sudbury, Trois Rivieres,. Vancouver, and Hull, before their settlement in ottawa. The reasons given for choosing ottawa were (it the existence of relatives (which was most frequently cited); (ii) possibilities to work or pre-arranged job; (aii) to learn the two offjcial languages; (iv) to study at one of the two universities; and, (v) because the Canadian Embassy in Spasn recommended ottawa as the best place to emigrate to in Canada.

The existenge of relatives is an important factor to be taken into account in the analysas of motives for migration in the case of southern European immigrants, but in our sample, the difference. between independent and sponsored, nomated -

immigration is very little: $55 \%$, and $45 \%$ respectively." This jarger representation. of non-sponsored (or Jindependent) inmigrants can be explained because of the large proportion. of single males in this sample $(23 \%)$ who came to Canada. in almost all cases independently, and not because of relatives in canada? who sponsored them. 'Another reason is to be found in the males' higher level education compared to the-females in the sample. As it is well known, the higher the educational background, the less the potential imaigrant needs to be sponsored by a relative, especially with the point system established by Canadian inmigration laws after 1967. 
IABLEE -4.2

Dístributtion_of_Sagele_by:Sex_and_Leyel_of_Edgucatíng

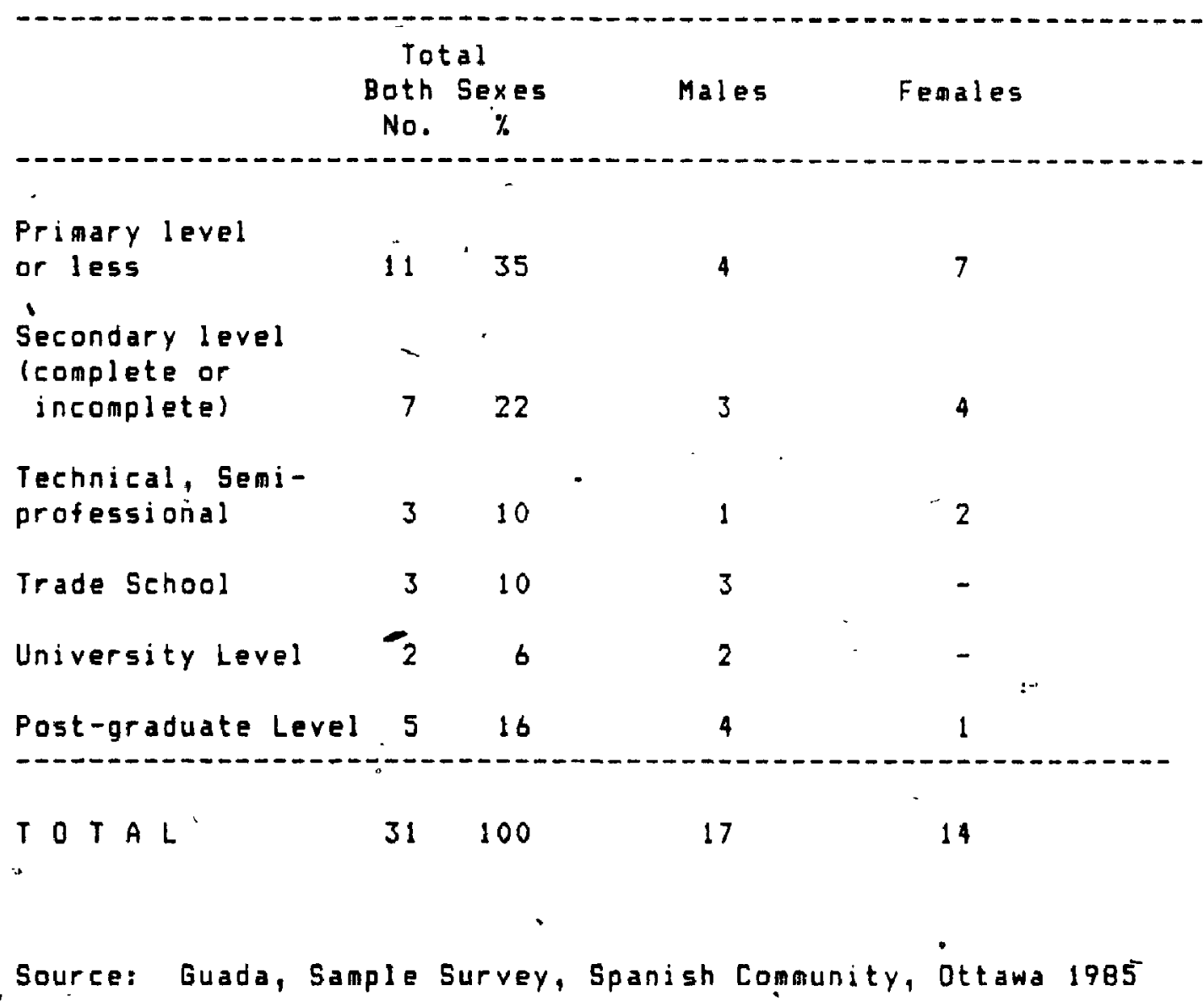

As can be seen from the preceding Table 4.2, the individuals in this sample seem to be distributed between two extremes: very highly educated $(22 \%)$ and those with a very low level of education, just elementary school and sometimes incomplete $(35 \%)$. The majority of the lowly educated persons were females (half of the female population), which reflects the traditional education pattern and the socialization of women in Spain, being prepared in life only to be housewives. It also 
reflects, the rural origin of both poorly, educated males and females. Most of them had to start working very young, sometimes in their early teens or earlier, to help their parents to make a living. This low educated group came mainly from the north of Spasn: Galicia, Asturias, Cantabria, where as we noted in Chapter II, poverty and general economic conditions lead people to emigrate. Galicia has tradjtionally been the origin of most Spanish immigrants to Latin America and United States, to the extent that in both the United States and Latin Ameraca an Immigrant from Spain is nicknamed "gallego" (Muñoz, 1972:53).

Twenty-two percent of the respondents ejther" completed high school or had some high school education and 10\% reported having attended a trade school in. Spain Imechanic, "maestro industrial", "hotelería").

Among the most frequently cited motives for migration to Canada by respondents were: econoinic, the superior Canadian economy, higher salaries and other general advantages. The data - presented in Table 4.3 suggest that having 'relatives in Canada has not been the main reason why the interviewees have migrated to Canada. In fact, 42 percent of the sample declared not having any relatives here in ottawa or in Canada at present. At the time of their arrival as mentioned earlier 45 percent were sponsored or noninated by relatives. Family reunion does not appear to be a very strong reason to enigrate to Canada. Apparently the presence of relatives is not a "major motive" for 


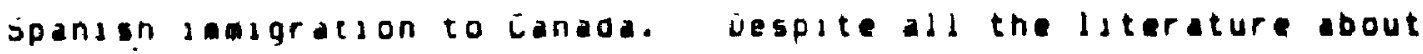
southern Europeans "chain igration", characteristic or strong motivation for family reunion iAnderson and Higgs, 1970 , Chimbos, 1980), Fereira Munzer 11981:10̈11 has argued that to understand Portuquese ianigration, "the extended family ls acting as tacilitatoro in the migration process rather than as the motivation tor higration". This appears to be the case for the 5panish Inalgrants ln our sample.

$\underline{1} \underline{\dot{B}} \underline{\underline{E}} \underline{\underline{A}} \underline{\underline{3}} \underline{3}$

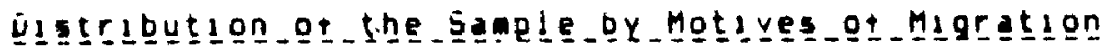

No.

i.

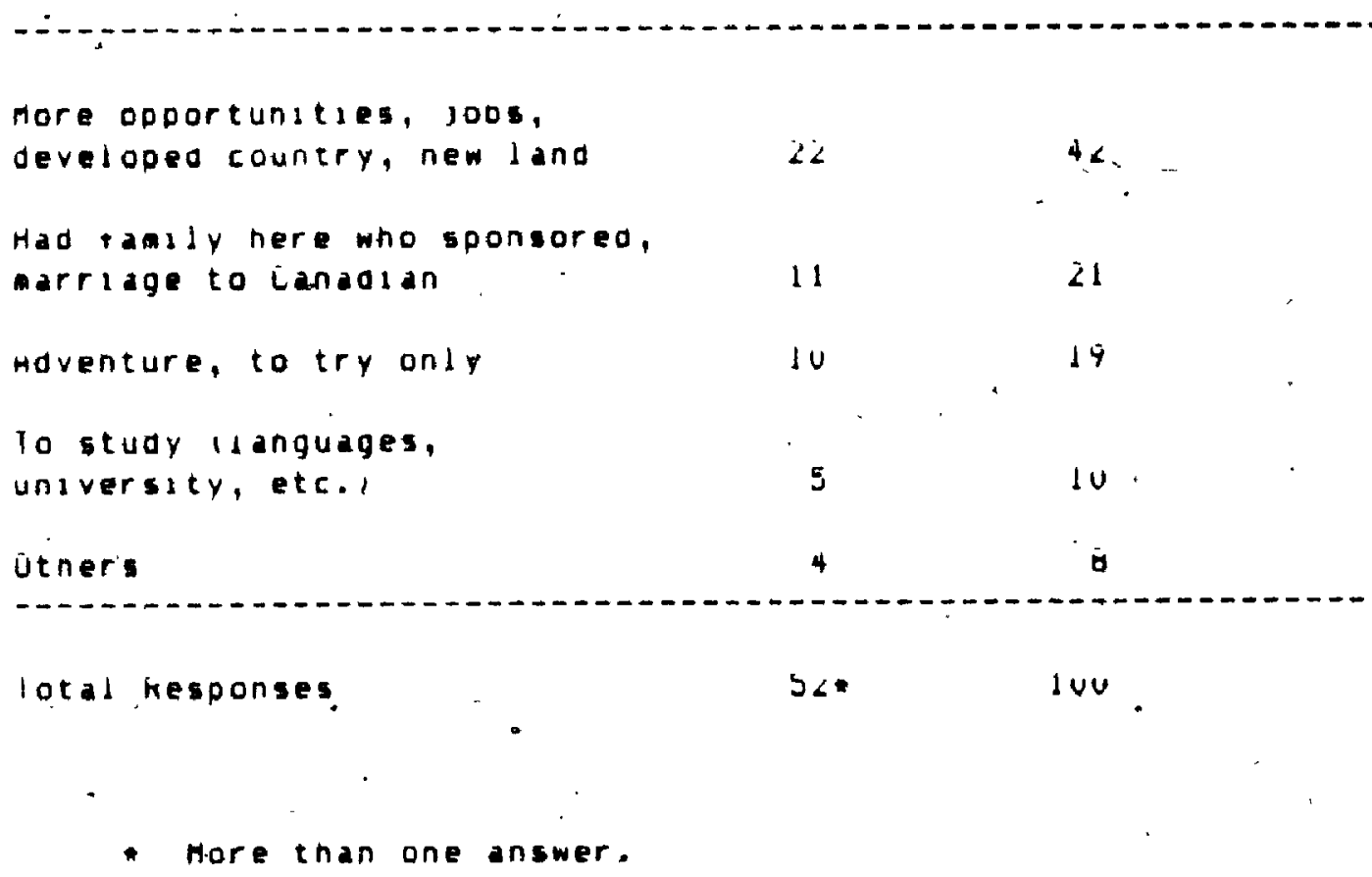

Source: Guad, Sample Survey, Spanash Comounity, Ottawa 1985 
Motives for migration to Canada do not oiffer very much for Spaniards frow other Southern European imagrants, especially Greks and Portuguese (Anderson, 1974; Alphalhao and Da Rosa, 1980; Nagata, 1970; Chimbos, 19801. The major factors for emigration to Canada are a low standard of living and fewer economic opportunities in Spain when compared to a superior Canadian economy, high salaries, advantages of social security, a better future for their children, and sometimes, adventure, "to. try" as half of the females in our sample reported isee Table 4.3). It was noticeable in the interviews that some female respondents claimed that their situation in Spain was not too bad but they wanted to come for a few years to see what might happen, i.e. for adventure.

South European immigrants usually leave their countries alone (Chimbos, 1980; Anderson, s1976; Alpalhao and Da Rosa, 1980), bringing their nuclear. families after they have settled jown and/or have become established in the new country. In this study, only six percent of the interviewees who were married abroad came alone to canada; in the ajority of the cases the nuclear family arrived complete.

\section{2) Settlegent_in - Cangada}

When asked about who helped them on arrival in Canada, the most frequent answer was the fomily, relatives and friends or acquaintances, especially from Latin American countries, and also Italy and Portugal. O The next great proportion referred to the 
help from the government, especially the Department of Manpower. The help from the government was mentioned with regard to economic support $(\$ 100$ weekly), English or French" classes, and orjentation to find jobs and housing. When analysing this aspect by sex, there does not seem to be any difference jn the source of hejp; only that formal help was mentioned mare oftencby males than females, but the difference is very $5 m a l l(10 \%)$. In addition, year of arrival does not seem to vary or change the importance of friends and relatives as the major source of help received. The highest proportion of those who reported receiving formal help arrived during the 1966-1970 period. During these years it would appear that immigration poljcies included extensive help for immigrants on their arrival; apparently it did not. exist in previous years.

Residential Concentration: On arrival in ottawa the hajority of immigrants in our sample took up residence. With relatives, generally in the east and west end of ottawa, Vanier, Hull and Gloucester. Others lived in hotels or boarding houses located mainly downtown. In every case the first residence was a transitional place until they could move to their own house or apartment. Almost 85 percent of the sample now own their houses, and the ones who still live in rented premises, are thinking about buying their own property very soon.

In the ajority of the cases the respondents declared at least two previods residences $/$ ottawa before moving to the 
present one. The distribution of the sanple ty present area of residence can be illustrated an Table 4.4 .

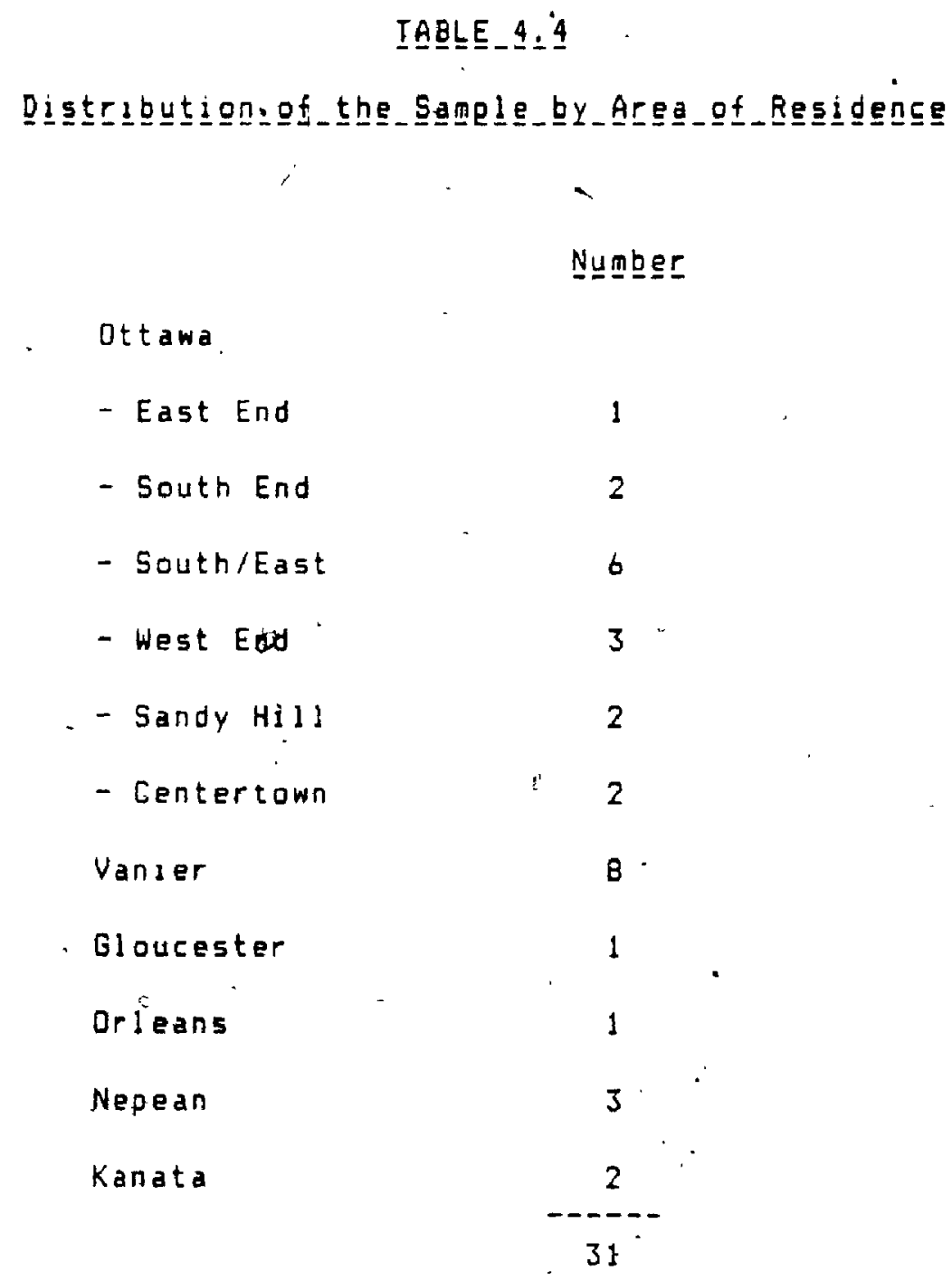

Source: Guada, Sample Survey, Spanish Conmunity, Ottawa 1985 י. 
Here we can see thạt there is not a strong residential segregation of Spanish immigrants, but it can be observed that there is a.tendency to live in two areas: Vanier and the SouthEast. Only in a few cases did the respondents report that the selection of area to live in took into account she presence of other Spanish people, relatives, friends or acquaintances. These five indjviduals live in Vanier, West end, and Gloucester. Two of them are mare household heads, who are more assimilated to the French culture than to the Anglo-Saxon; they are married to French-canadian women and presently live in Vanjer la predomsnantly French area) because they feel more comfortable there.

In relation to the interviewe's satisfaction wath their loeal communties and neighbourhood, almost $80 \%$ have not thought of moving or changang to other areas or houses, and those who would move in the future gave the same reason: to acquare a better house than the one they presently own, or to buy thesr own first houses.

D

The reasons given for satisfaction with present restoence are very general, mainly becaúse they like the area loeautiful, calm, residential), they are used-toit, it is practical (near -job, school, and recreational servicesl. None mentioned Spanish community-related reasons.

The majority of the nesghbours are Canadians, with very few exceptions where non-Canadian neighbours were mentioned; only $29 \%$ 
declared to maintain any relationship or contact with neighbours. The majority argued the difficulty in establishing any pramary relation with them, except for sporadic visits and a very superficial relationship.

11. OCCUPATIONAL ADJUSTMENT

As noted in earlier chapters, economic adaptation of immigrants is a very important stage in the integration process. In this study the economac experience of the dmigrant was taken into account, insluding the occupations into which they have moved, thesr. difficultes encountered, job seeking behaviour, their present occupation and satisfaction, amongo other aspects. Sacco (1958) in his study of Spanjards in Quebec found that, sumilar to other immigrants at the initial stage, gtheir adaptation to Canada is economic; dependent mainly on the better standard of life that they are able to acquire. If this adaptation occurs quickly, their general integration (social and, culturall to the wider soczety will be quacker.

At least half of the andividuals an this sample have cone.

- from rural areas in Spain where they had a low standard of life, most of them came to Canada without any qualifications. Comparing their present situation with their former situation in Spasn they have experienced some dipward mobility; even though they have accepted and still do low status jobs in canada. The income they now obtain, conpares, favourably to that received in. Spain. 
The coricentration in higher or lower occupational categories has been often used to measure the economic adaptation of immigrants though there have also been considerations about the economic suctess of immigrants concentrated in certain ethnac spècialties. With the small size of this sanfle we were not able to deteraine an ecorionic specialty for Spaniards. They seem to share south European occupational niches: Janitors, domestic service, waiters, construction workers, etc. On the other hand, in terms of econamic success of "Spanjards in hagh status occupations, that 35 , with hagh incomes it was intended to inferview the owner of the one of the biggest corporations an the construction sector in Ottawa who is a Spaniard, in order to find out if his firm constituted an ethnse enclave in ottawa. After many attemptsaxinowerer, it was"not possible to collect these

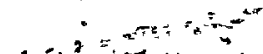

sata. We do not have the exact number of entrepreneurs. and self-

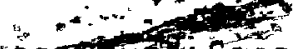

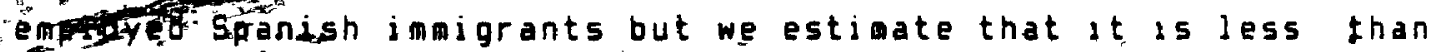
$10 \%$ of the total population of this immigrant-group in ottawa. There are only four íases in our study that are self-employed: one.in the electrical engireering area (for three years), another in the restaurant sector (12 years), one female embrojderer who is an employee and also a homemaker, ond one, small entrepreneur who is: employed full-time in an Italuan firm, but also has his cwn, construction firm fogerepairsl. Onby two of these

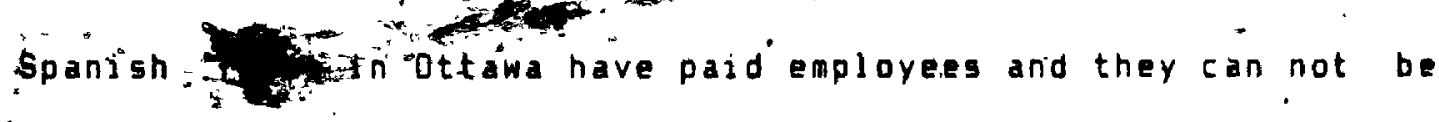
- considered to be ethnicomployment enclaves for other spanish immigrants. None of these pinority enterprises was stinulated by the demand from specific ethnic markets: that is these ethnic. 
Iharty-five percent of the sample arrived wathout a specifie intended_occuleation. They reported that theycame to craada willing to fake any job no matter where it was located and even if this meant a shift from their previous occupation. Some professionals or qualified individuals declared that because of their language problem and lack of Canadian experience they were prepared to accept anything. Another thirty-two percent insended to perform their own trade or profession, "and nineteen percent expected to work in the service sector Imainly as wajters, cooks, domesties, ete.). A small proportion (13 percent) came with idea of learning a language andlor. of continuing thesr studies.

With respect to the first_job located in Cariada there was a concentration (14) in service occupations (45\% of the total sample), mainly cleaning staff, cooks, waiters and dishwashers: This coincides wath the large proportions in the service sector observed in the intended occupation, of landed immigrants for the 26 year period-considered in this study (see tables 3.7 and The rest of the respondents were represented in various occupation categories as follows: skilled workers $(10 \%)$, nonskilled workers $(16 \%)$, professionals (13\%), clerks $(10 \%)$, technicians, semi-professionals $(10 \%)$. (See Table 4.6.)

Generally speaking the immigrants who cane to Canada before 1961 worked on farms or in the service sector, with the few exceptions of one.or two university professors. During the period 1961 to 1965, the Spanish immigrants primarily found thetr 
first job in Canada as domesties and cleaners, etc. The period 1966 to 1969 corresponds with the Expo 67 in Montreal, which yttracted wajters and chefs, or they came to-pttawa becauce of the construction and development of new hotels and restaurants. During the early 1970's, which, was when most of our sample cane to Canadai. their first jobs showed a tendency to be concentrated in skilled trades (machinists, mechanics, electricians, etc.) and also, as was the case in earlier periods, in the service sector. After 1975; as pointed out before, very few Spanish immigrants entered canada, withothe exception of professionals or workers with pre-arranged jobs.

\section{IABLE_E}

Distribution of the Sample by sex and "First" ofseugation_in_Eanda

Total No. $z$ Males Females

Professions

$4 \div 13$

3,

Techaical, $3+10=3$

Clerks, sates (hhite collir. oceupations)

3. 10 :

Service

14

45

$\because$

$\frac{1}{\because} \div \div$

skilled or semi-skilied*

3. 10

2

2

Non-skjlled**

$4 \therefore 16$

1

3

TP TAL

31.100

17

14

* Such as mechanics, machinists, lectricians.

* Such as general labour in construction and inafacture - industries

Sourche ouada, Sample Survey, Spanish Community ottawa 1985 
The ifiest job in canada was.found through frqends; acqualutances or relatuves (more than half of the sample). This job seeting behaylour in the case of southern European immigrants has beent described extenstvely by many scholars (see Anderson, 1974; Muñoz, 1972; ChImbos, 19801. Others found thesr first job through other channels vad fewspapers, want ads and darect personal application at the workplace (35\%). It is evident that persunal. networls have been the most, efficient method for spaniarus to firda job, especialiy their first one:

Ihe. importance of unformal social networks for immigrants in the job searching process, not only.for south Europeans but for other Immigrant. groups, bas longbeen known (Reyaqlds, 1935; $\operatorname{lur} \tan , 19761$.

Apparently the first job was found relatively quakly and $\therefore$. none encountered any problens at the workplace; the few eptions were females worksng an clothing factories where; exceptons were females warking an clokhing factories where; aceording to then" the workind "énditians were thot very satsstactory. Arnopoujos $\because(1979)$ also referred ato this" exploitation of immigrant women in her study, of the garment woubtry and domestic servace in Montreal.

With respect to the duration of the first job. eleven - individuals stayed.for less: than six montris, eight for one to two years, flve for three to flve years, three for six to ten years, and two. who have been performing the same job since artival in

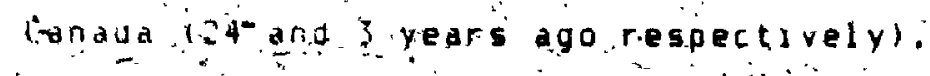


The reasons for leaving the first job that the spanish imajgants. in our sample located in Canada are mainly economic, that is, because. they found a better paying jott or one with better general working conditions. In very few cases (3) were they fired or laid off. It should be pointed out that in the case of females, the same pattern applies but chilobearing was an additional reason for leaving a job. The interviewees declared an average of two to three jobs before their present job. It wight be possible that the respondents did not report all the different jobs they had had in Canada, only the main ones since 0 . arrival; hence, it may be assumed that this average number of jobs may be higher.

As mentioned earlier, the ofcupational distribution of Spanish immigrants in Canada is not available in the published cengus data la special tabulation could be run but the cost - is prohibitivel. The data in Table 4.7 suggesf that presently there is a tendency fof Spanish immigrants in ottawa to be working in - the service sectori. These are low status jobsin the wider Canadian societyi. in the case of feriales:this is especially trued On, the othef hand, there.is a small concentration in higher occupational: categories such as the naturas stiences professionals, university prafessors (Spanish languagel, and other professions. Most of othe individuals in these high status occupationa areinen. 
IABLE_ 4.?

Di gtribution af the Sagele_by_Sex_and_Present_Qgecugation

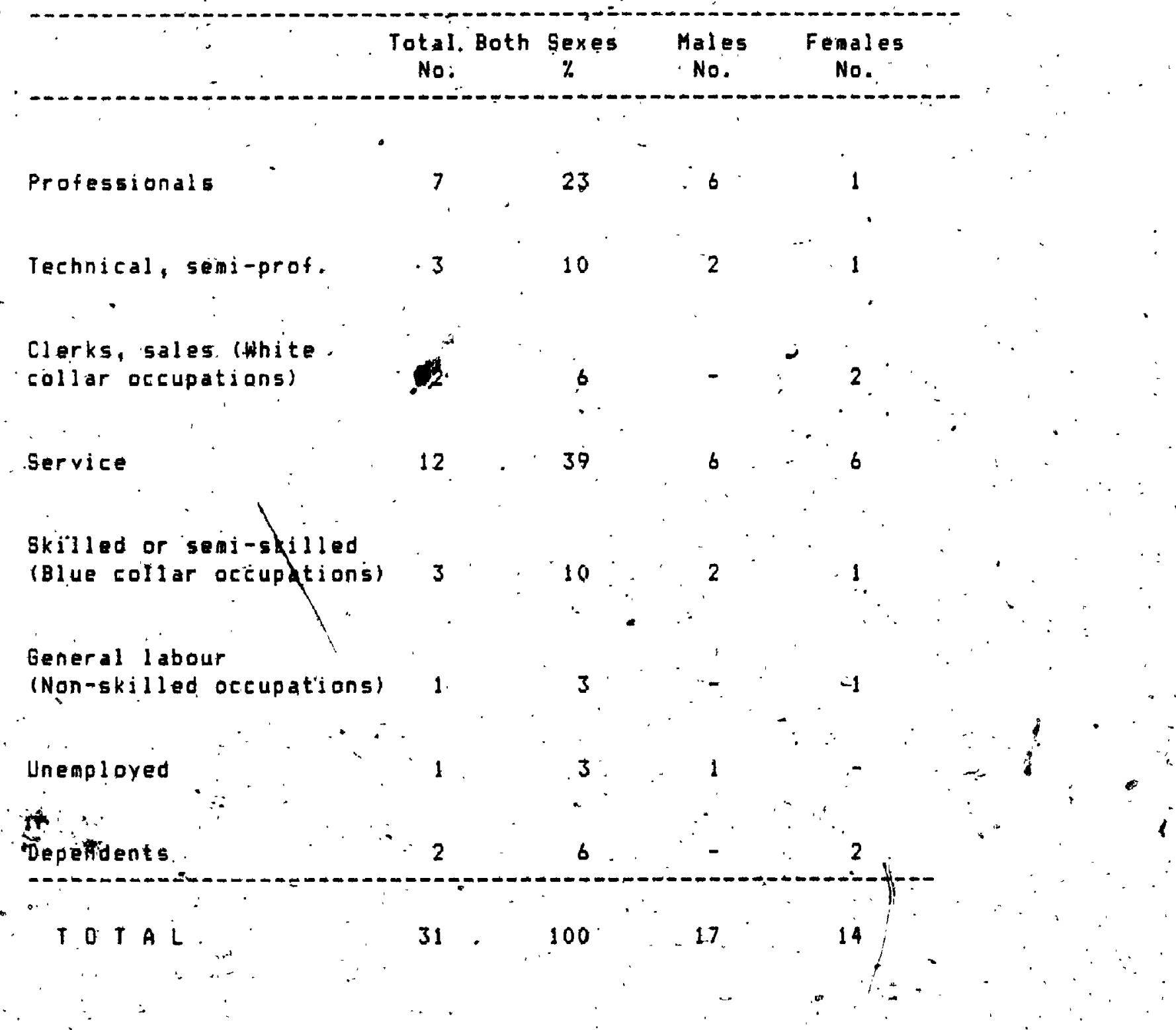

Sourcel Guada, Sample Survey, spanish Comminity, ottawa 1985 
The coricentration in kigher or lower occupational categories has been often "used to measure the economic adaptation of immigrants though there have also been considerations about the econonic success of inmigrants concentrated in certain ethnic specialties. With the sinall size of this sample we were not able to determine an ecorionic specialty for Spaniards. They seen to share south European occupational niches: janitors, domestic service, waiters, construction workers, etc. On the other hand; in terms of econonic success of "spaniards in high status occupations, that is, with high incomes it was intended to interview the owner of the one of the biggest corporations in the construction sector in Ottawa who is a Spanjaro, in order to find out if his firm constituted an ethnic enclave in Dttawa, After inan attemptsonowerer, it was not possible to collect these

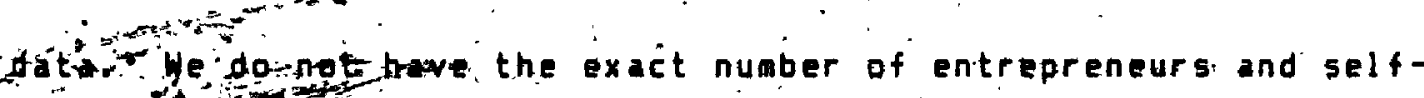
$\therefore-3 x+4$

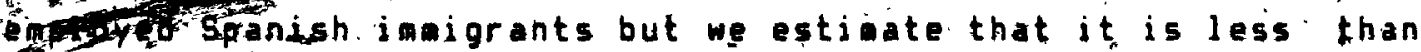
$10 \%$ of the total population af enis jmatorant-group in ottawa. There are only faur éses in our study that are self-employeds one.in the electrical engimering area (for three years), another. in the restaurant sector (12 years), ane temale embrojderer who is an employee and also homemaker, and one small entrepreneur who is. "empioyed full-time in an Italian firm, but also has

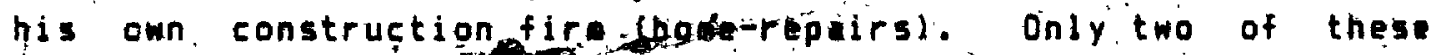

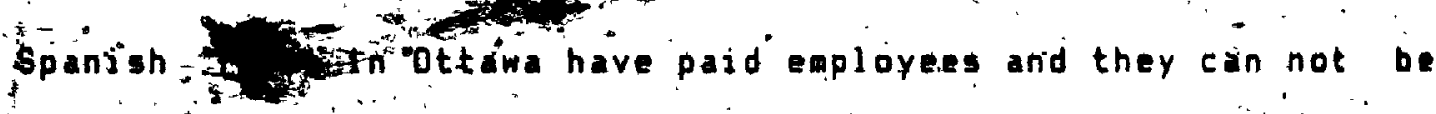
Fonsidered to be athnicoemployment englaves for other spanish immigrants. None of these inority enterprises was stimulated by the demand from specific othric markets! that is these ethnit. 
businesses are- not filliduthe demand for specialized requireants from specific ethnic markets, as has been shown to be the case imong other infigrant groups.

Neverhteless, it should be noted that there are interethnic, relations between the Spanish imaigrant group. ànd the Italian ethnic group not only occupationally speaking but also socially. One in five of the sample have worked in the past for an Italian business or presently do. It is interesting to point out that we fotind in our sample some. individuals who learnt Italian before English because they wereworking for ôr with Italians. We: will see later how those two groups are related with respect to social*networks.

Table: 4.8 indicates the present employers of spanish inmigrants in the specific case of our sample.

During the intervieins people frequently expressed an interest. in getting a job in the public service in the future. manjy because of the advantages, notably.the stability, that these jobs seem to offer: Those who have not ret obtained their Canadian eitizenship, sould be willing to do sid, if they were able to find job in the public service: This is not surprising since the Federal Public service is the gajor employer in the ottana ares. 
IABLE $4 . B$

Present_Engloyers of the_Sgani sh_Resgondents_by_Sex

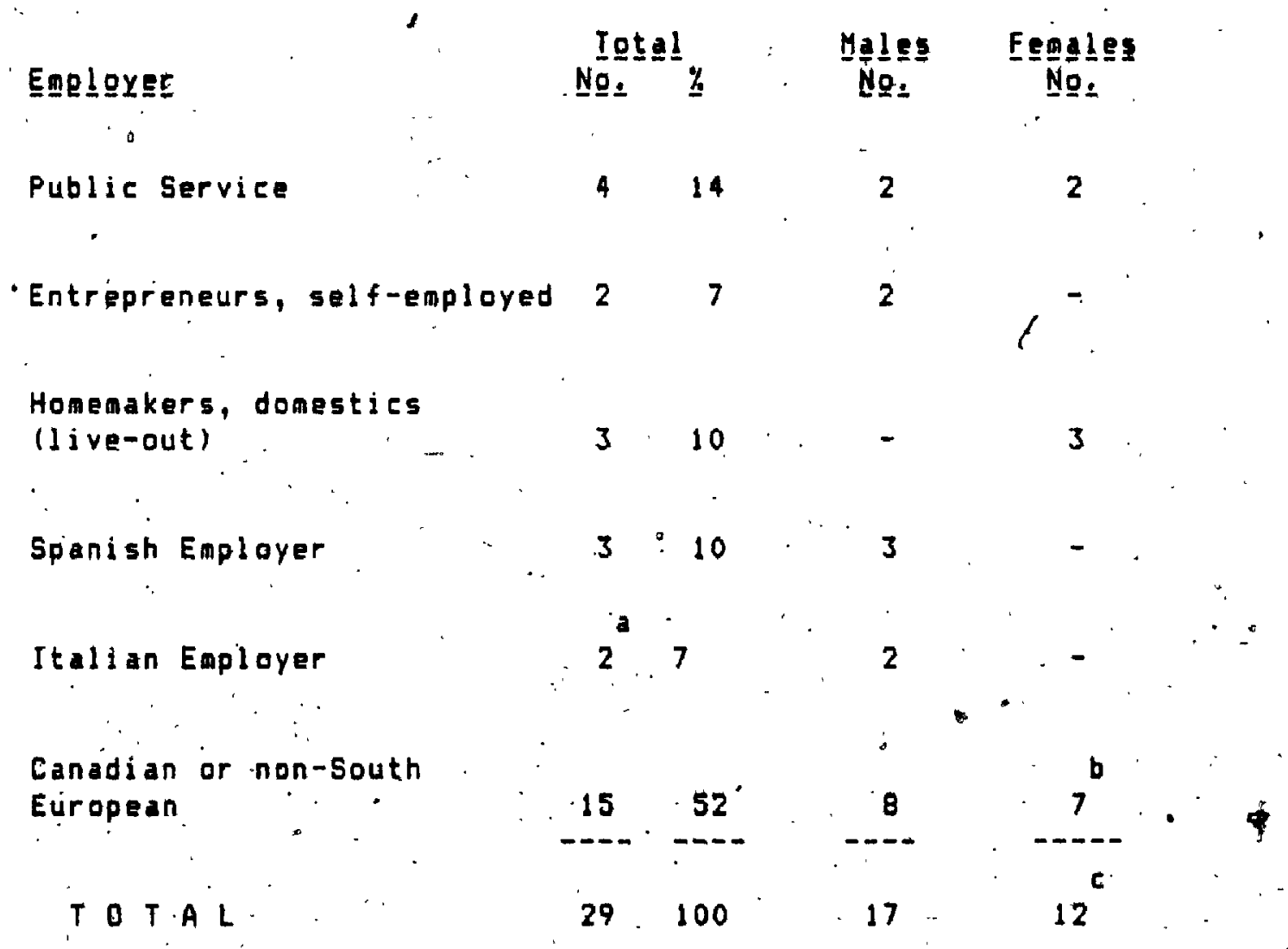

a. One nale is also self-eiployed.

b. One female is also self-eaployed.

c. Two fenales do not work at this time.

Sourcei Guada; Sample Survey, Spantsh Comanity, Ottawa 1985 
Ht the oeginning of this chapter wo noted tnat women are

most ly concentrateo in. jobs considereo menial, wath low prestige," aunly in the service sectorl malds, cooks, live-out oosestics. etc. Ihese jobs are abo consudered to be "moblitty traps", unrewarding and because there ls practically noneco to speak tnqlish, akes the asy tor inatgrant woan to enter. rone oi the interviewees reters to ner job in those terms:

"i a a ald in one of the well-known hotels in ottawai they treat me well, especialiy iny boss, who la canadian, out this the kind of job which does not give you the opportunaty to move upwards, to progress, to learn new things. In other jobs, with tiae you prosper, advance. out nere you stagnate, and besides tnis, you never isarn to speak-English or. French because ant of your. coworkers also speak jojpntsn...'

in the jpanssh tradition women are not incorporated in barge number in the labour torce compared with other industrialzied countries. Nevertheless when they eaigrate work is. necessary it the imigrante intend to achieve their goals in general, and especialiy to increase their tanily income. The majority of the wowen in pur sapjépork in.the pubilic sphere, outside the home. 'venerally they are pald by the nour because of the flexifollty op the service occupations in terme of avajiabla tian to pertore their domestic labour at hose. Part-time jobs of this type are generally better.pald, especially in the case of livebut oomestics, in prjyate housenolds lasinly in the frockelifte areal because. it is common knowledge that there existe the deand in cinada for this kind of job, gince it is usually rajected by Cindosens. This sutation was also found in western Europe, 
specifically in France and Germany in the case of $5 p a n i s h$ female immigrants (see MuKoz, 1972; Diaz Plaja, 1974, Rubio, 1974 ).

Women also work for goyernment institutions as cooks or cleaning ladies (hospitals, homes for the elderly, etc.) and for. hotels, restaurants as maids or waitresses.

Five of the women in our study started working on their arrival as cleaning ladięs in offices or institutions hospitajs, universițies) because it was an occupation available which did not demand knowledge of the English or. French. languages and/or special skills. Also, because they had small children they could work as cleaners at night. Only two of then remained as domestics, the others changed to occupations where they were using their skills brought from their homeland inursing, embroidering, seanstresst.

Qf the narried men ( $(\theta)$, most of thejr wives did not work because they had fall children, or the husbands did not want them to work. 'Only two of their wives worked, one as a secretary and orie as lab technician. In both cases the awives were. nonSpanish Canadians. Apparently for Spanish males the rassing of the children by the mother is a very important value. In addition the cost of sending the children to daycare or having baby-sitters is beyond their meansa since the Spanish wives wauld have been in low Aying manual jobs,. On the other hand, not trusting. children to itrangers seens to be typical of southern 
European inmigrants groups such. 35 Portuguese and Greeks lAnderson and Higgs, 1976; Chambos, 1980; Alphalhao and Da Rosa, $1.980 ;$

To sumarize: most of the women in our sample lack skills relevant for an industrial society such as Canada, therefore thear occupational stalus is generally low. For those with only a few. years of education the average rank on the bilishen and McFoberts scale (1976) is 449, while the ones who had secondary, trade or technical school in Spain have an average of 199 on the same scale.: Only one of the temale respondents has a university degree; this calf be considered an exception; her occupational rank status was 1. Controlling for age and length of residence does not appeaft to differentiate the occupational status of temales.

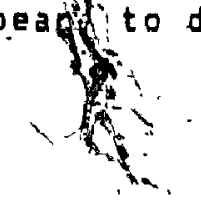

Analysing the occupational concentration of males itable 4.7) it may be observed that they are distributed either in low status óccupations $(53 \%$ or high status occupations $(41 \%)$. If we compare the occupational ranks. in the Blishen scale, controlling for sex and education we can see that poorly educated males have a higher average rank. (367) than females with the same level of education (449). According to Blishen and Carrol, men tend to be - concentrated in lower. prestige occupations having low educational levels "bưt are pajo goodudeal more thän momen" (1978). In the case. of individuals. with an interinediate level of education. (secondary, technical or trade school), females appear to be 
doing better than males in terms of occupational ranking: 199 and 354 respectively. Females in female dominated occupatioris have lower prestige in the overall occupational hierarchy, but receive higher esteen as members of an appropriate feade occupation i.e. nurses, secretaries (Blishen and Carroll, 1978). It is not possible to-compare females with university education and males because of the small numbers (only one). 'In any case, the average occupational rank for males, with a high level of education is 35 on the Blishen seale.

In the male professional group (b), two obtained their? degree and training in Canada, whereas four arrived in Canada with a upiversity degree. Except for the engineers they tended to have fewer number of jobs than the rest of the respondents. Only one of these engineers has experienced occupational dislocation, working on his arrival in a lower status occupation (machinist) because of lack of certification and knowiedge of the lahguage. This respondent pres ently has his own business and may be considered economically successful un Canada, after being in the country for only eight years.

Males who are presently working in the service and construction sector, generally. started working on arrival in Canada in the same area, mainly as waiters (1), dishwashers (3), cleaners. (2), cook (1), painter (1). Very few have moved to other occupations, although they have experienced some upward aobility in terms of salary. 
Only two of the male respondents work for the government, one as a draughtsman and one as translator. Both emigrated from other countries en route from spain, and received most of their education and training in Canada.

In terms of unemployment only a few of the spanish jmmigrants have collected unemployment insurance or experienced unemployment to date. Only six males and four females have been unemployed while in Canada, and the average time unemployed was one to three months. During the interviews they critized how somé Canadians and some other immigrants live on unemploymert insurance just "because they do not want to work". Portuguese also seem to have a low unemployment rate as pointed out by Alpalhao and Da Rosa (1980).

When female Spanish immigrants in our sample were- asked about their husband:s gccugatign, seven reported that they are in skilled or seni-skilled occupations (one is Portuguese), twd iñ servite occupations, two professionals (one Czech), one technician, one salesman and one unemployed (French-canadian).

In more than half $(58 \%)$ of the householos, there is only one person who works' outside the home. This is a high concentration of enezearner fagil persons work, and 13\% where more than two meabers of the family work. This may be explained because of the preponderance of single males in the saple and may be due to male respondents not deciaring that their wives were working. 
The average hours worked for females was approximately 22 whereas, for males, it was 37. The respondents who declared more than 50 bours a week were thoge who have their own small enterprises. There were only two cases where the respondents held two jobs at the same time: they are employees in private" firms and also have their own business construction, embroidery). On arrival in Canadathis situation was more common, as five of them pointed out in the interviews; they needed to have more than one job in order to make enough money to be able to save.

In this study it was difficult to obtan the total household income. The apprehension towards answering this type of question is well known, and this uneasiness was shown in the collection of the data. Therefore, the possibility of error was great and as a consequence this indicator for the evaluation of the econonic position, of the spanish immigrants in ottawa was got ...

used as intended at the beginning of our research. We were only able' to. optain a very general appreciation of thear socioeconomic standard of llfe, occupations find other observations during the process of the interview.

just as in the case of job-hunting channels for the first occupation in. Canada, sübsequent jecupations have been found through informal networks such as relatives. and friends. For the present occupation, the situation changes because a large number (i5) reported formal channels of job searching such as: 
newspapers, unions, pre-arranged jobs or personal applications at the workplace, compared to ten individuals who used personal networks. Maybe, the interviewees, especially males, did not mention friends or relatives as job hunting channels to appear mare efficient or self-sufficient to find jobs, or it might be the case that on arrival or during the first years in Canada, frjends and relatives were more important because the newcomers did. not know the language and lacked Canadian experience to use formal procedures for job applications.

The former aspect seens to be related to the factors that Spanish zmmigrants in our sample consider important for economic achieventent in Canada. Half of the respondents give priority to knowledg of the language (mainly English); in second place they mentioned "who you know" (friends or contacts), and also to be patient, flexible and work hard.

With respect to the length_of_time in their present occupation the average number of years was morethan ejght years $(45 \%)$, followed by 3 to 5 years $(32 \%)$, and 5 to 7 years (6\%). Only two fenales (6\% of the total sample) have been in their current occupation for one or two vears. This relative stability of Spaniards at work has been observedin Western Europe by several scholars (Muñoz, 1972; Diaz Plaja, 1974).

When asked about their intentigns_to_change if they were offered better jobs, $42 \dot{\psi}$ would not change their occupations, $32 \%$ 
would consider a change, but only if the offer was extremely good; the remaining 16\% do not know at the moment. The male respondents, who would like to change their present occupations refer to the possibility of finding better jobs' in anothertirn, better positions naybe in the same workplace, - or only when they are ready to start their own business. Women tend to be more "conservative" about changing jobs or positions; they refer to the lack of knowlege of the language as an obstacle to move from their current occupations. This aspect is relevant in the case of service occupations. Another aspect mentioned by females is their age which makes the possibility to change difficult not anly because they do not want to start all over agan but also. because they would lose their benefits.

The four respondents who wark in the governient interid to stay in their present jobs for the security they have in those positions.

The "ideal" occupation for $29 \%$ of the respondents corresponds with their present occupation, whereas for $39 \%$ the "ideal" occupation would be a different one, in another area. Another 39\% pointed out that their "ideal" occupation would be the same as they are in now, but performing higher positions or. establishing their own businesses.

Those who declared being completely satisfied $(32 \%)$ with their jobs seen to be the onis who are performing their "ided" occupation. Others who are just satisfied with their present 
occupations (55\%) would like some changes either in the same workplace or in another area or sector. Only six percent of the total sample openly mentioned that they were not very satisfied with their present jobs.

The reasons given for general satisfaction in the present job were good income and benefits, good atmosphere and treatment, and flexible, hours.

\section{ACCULTURATION PROCESS.}

As stated before, language is one of -the main indicators of the cultural incorporation of immigrants. Lack of fluency in the host country language, as mentioned earlier; is one of the major barriers to integration into the wider society. It is usually closely related with other aspects of the adaptation of umigrants, for example with occupational adjustment, social -incorporation and other aspects of cultural incorporation (Reitz; 1980afchiabos, 19804 Roggs, 1974; Fisher, 1979; Weinfield, 1981):

It is djfficult for the first gereration jamigrants, even if they know the language, to acculturate, because they have different values compared to those of Canadian society; generally this crates conflicts. Very frequently first generation immigrants do not have a command of English or French, that is they are fot fluent in either of the two official languages." Alaost without exception, the ability to speak English or French by the Spanish imaigrants selected. in this sample on arrival is: 
very low (Table 4.9). This language deficiency is, in part, due to their low level of education, not beyond elewentary school in many cases. Those females who did not have language skilts, recognized the necessity of improveaent and being sometimes - "ashamed" for not knowing either of the official languages in Canada.

IABLEE-4 $=$ ?

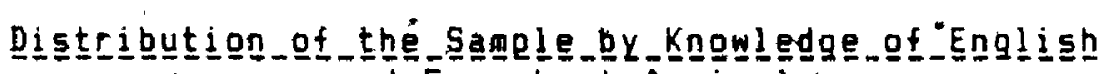

and Erench_at_Arrival

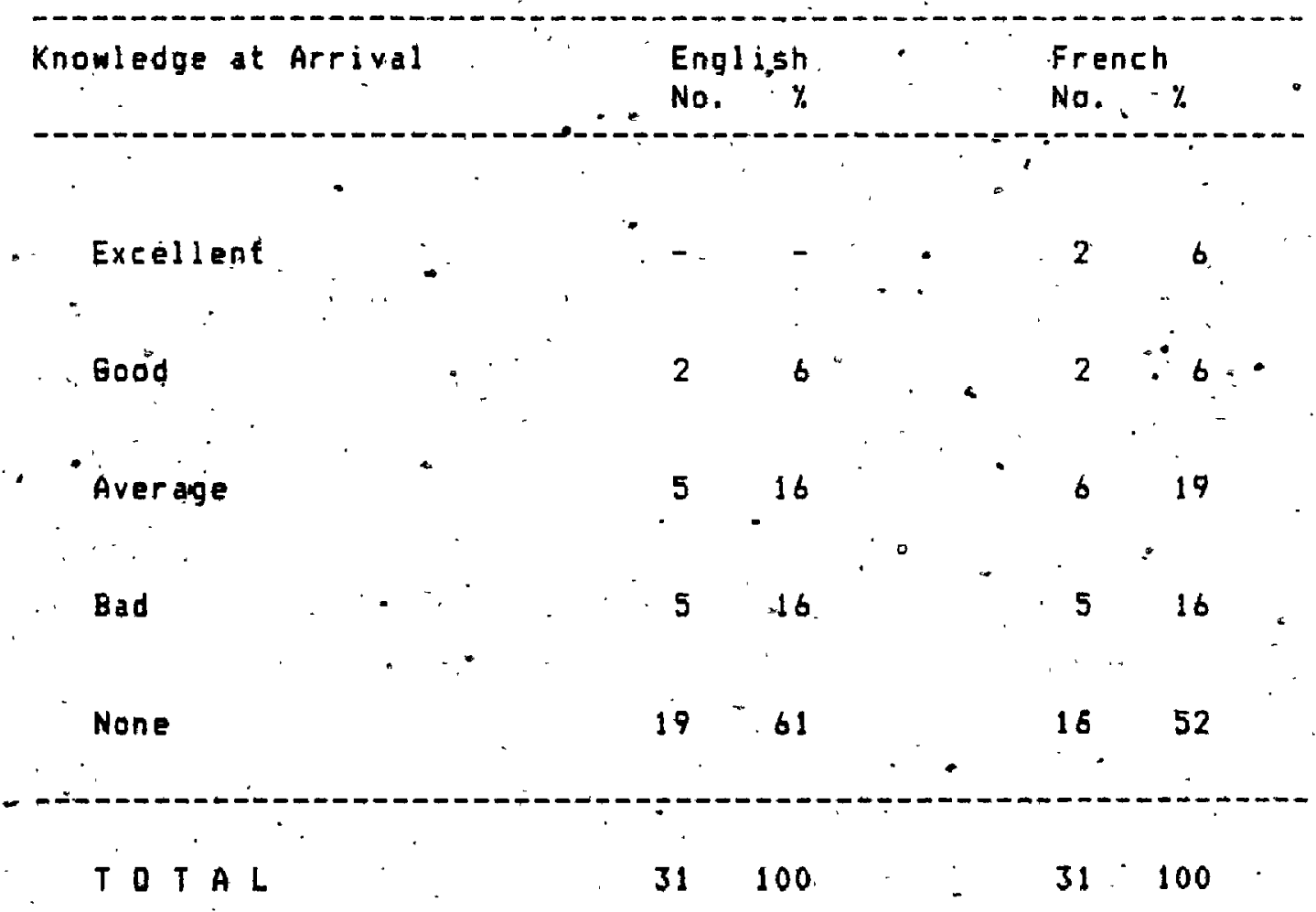

Source: Guada, Sample Survey, Spanish Community, Ottawa 1985 
In this study the males were currently morefluent in the Gomiciant language, mainly because of the lower participation of women in the wider society lchild.care, low educational level, menial work, non-attendance to language schoolsietc.).. (See Table 4.10 .1

IABLE_- $4 . \underline{10}$

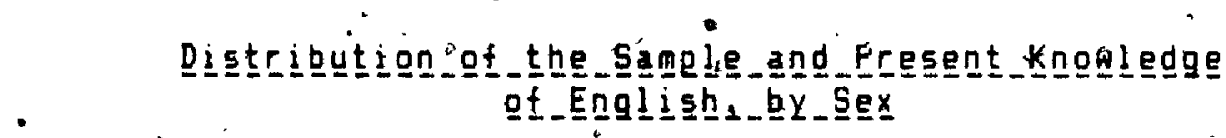
of_Engl ish_by_s

$\begin{gathered}\text { Present Knowledge } \\ \text { of English }\end{gathered}$
Excellent
Average

Source: Guada, Sample Survey, Spanish Comanity, Ottawa 1985 
The use of Spanish at home is relatively high, over $70 \%$ spdak mostly spanish at home, while only 19\% of the total households speak mainly English at home; ten percent usually speak Ffench at home.

$\infty$

Parents,. nevertheless, were unanimaus in their suppopt of bilingualisa" (English-Spanish' or French-Spanish) for their children. Dnly in one household did the children not speak any Spanish. .

Sponsored inaigrants are-often placed by thear sponsors in job situations where no English or French needs to be spoken. In this type of-situation they can manage with no English or French, especially if they, have other individuals at work who can be used. as interpreters on occasions.

Forty-eight percent of the sample speak mainly English at work although a little Spanish can be used. Bnly four individuals mentioned the use of French at work, "and it is interesting to point out, though the frequency is very low ionly two respondents) what sone use Italian at work, as a consequence of having Italian employers la, construction.worker and a hairdresser). A large proportion of the sample, however, hentioned that they worked for or were related some point in the past to the Italian ethnic group in Dttawa. Thus, special attention should be given to inter-ethnic redations in further research, particularly where latin-root languages areconcerned; this way be an juportant factior in the integration process. 
Three of the working women interviewed in thls study noted that the trae of work they have had since arrival in canada has not demanded much ability to speak English (domestic service). Inerefore, there ls less incentave for them to shift to the dominant language. Generally, the husbands of those women who do not speak English.at all to not command the language as well, and their children are in many cases their interpreters.

Although the proportion who daclared they spoke English (29\%) seems hagh, at would appear that in some cases the use of the lanquage is very, limated, only a few technical words or compion expressions.

A higher proportion of males (71\%) attended English (or French to a lesser degreel language schools than dad females, $(36 \%)$. Most of the lmagrants who arrived in the early seventues took classes pald by the government; others did it independently, or learnt Erglish in high school ltwo cases of second generation

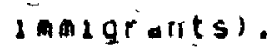

: hnowledge of the Frengh_language by the Spanish respondents was also. very poor on arrival in Canada (Table.4.9). This is related to the low level of education of mast of these spanish imigrants. If they had attended secondary school in spain.they would "hive. learnt sone French since it is compussory at that level. They would then have been in the position of the Portuguese innlgranty do deséribed in Andefson and-H19gs $-(1976)$. 
When asked about their current ability to understand, speak, read and write both languages, English and French, the ajority declared to have improved, Aspecially in English. Males seen to have progressed more than fenales, but in all cases they still retain a foreign accent and their writing is generally very poor since the level of work they do means that they do not need to write it very often.

It is interesting to note that length of residence does not. necessarily' improve 'fluency in English (Table 4.11).

\section{IAB}

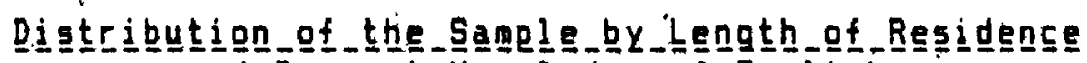
and_Present_Knowledge_of_Eng! 1 gh

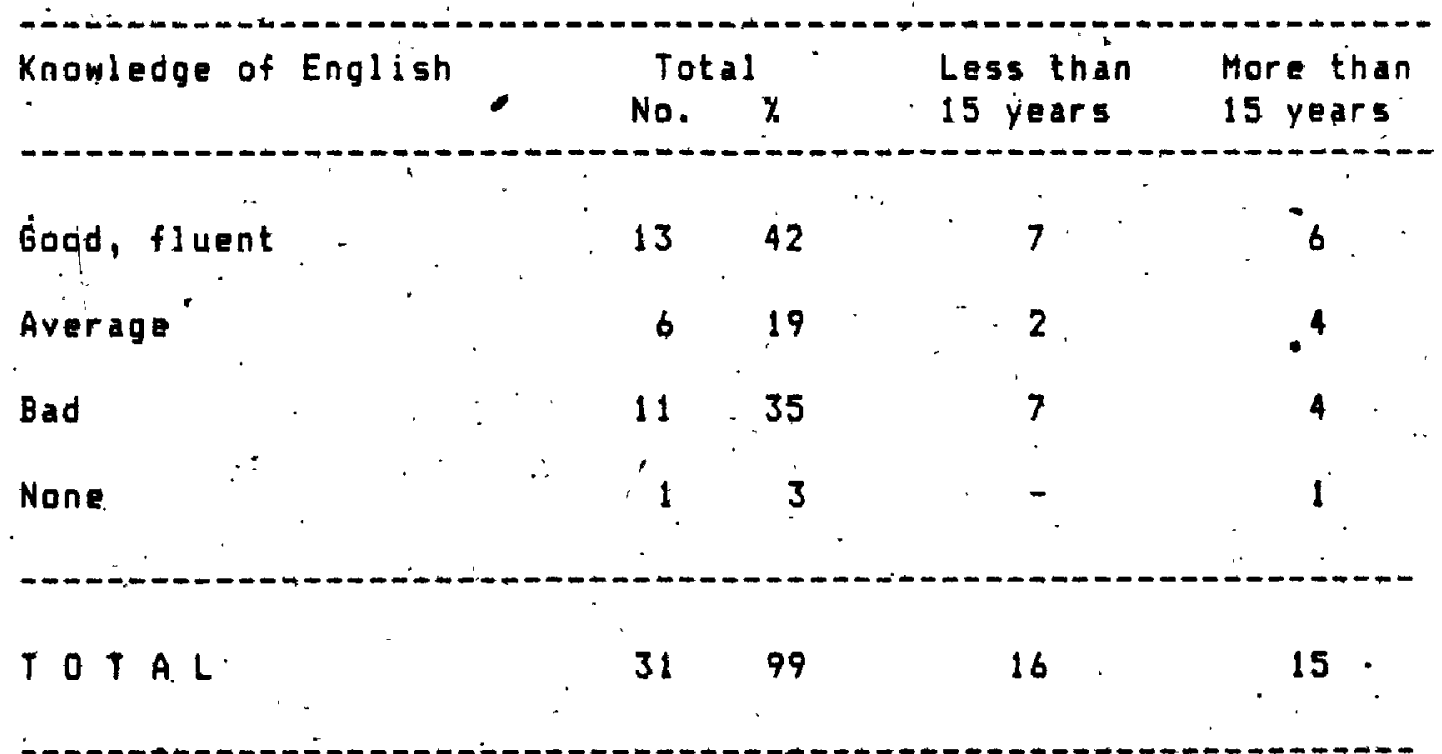

Sources Guadi, Simple Burvey, Spanish Community, Ottaha 1985. 
un the other nang satistaction witn late in the nose society

1. an important iactor to take into account in teras of cultural integration. Like the Greek and fortuguese imatgrante iChimbos, 1980́, Nolvo, 1984), Spaniards are generally satistied with their lite in Canada. The present study showed that 20 of 31 responoents are extremely or very satiseied witn Canada. This satsetaction appears to be associated with the greater economic opporeunitien in general, and to be living and working in a are developed country. The males especially ade reterence to this aspect. fendes are very iapressed with the efiticiency of services:- uther reasons for satisiction with lite in canada are the order, organdzation and formality existent $119 \%$ of the total sample', as, well as ireedon, equatity and respect for rights $123 \%$ ot the 31 responoentsi. Hl] these aspect were mentioned as the wost important positive aspects oi ianada by the interviewes.

There is. a tendency to be more satisitied with length of residence in Canada as it can be seen in Table 4.12.

When the Spanish respondents were asked what did they like least about canada" or. tound more difficult to get used to, 14 people cited the weather, speciticaliy the very long winter and continuous living inside the Fouse as a consequence. other inegative aspects that were centioned are high taxes, the people inot open, "cold", quiet, lack ot "joy", etc, d, different way of lote and values lweak family bonds, perimserveness, etc.l. All. these indings are supported byother studies of spaniards. and South European tho garants wrich have been carried out in canada 
and Western European countries (Sacco, 1958; Chiabos, 1980; Rubio, 19741.

\section{IABBLE_E_4.12}

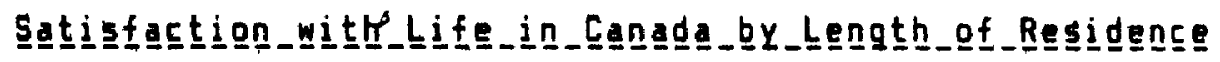

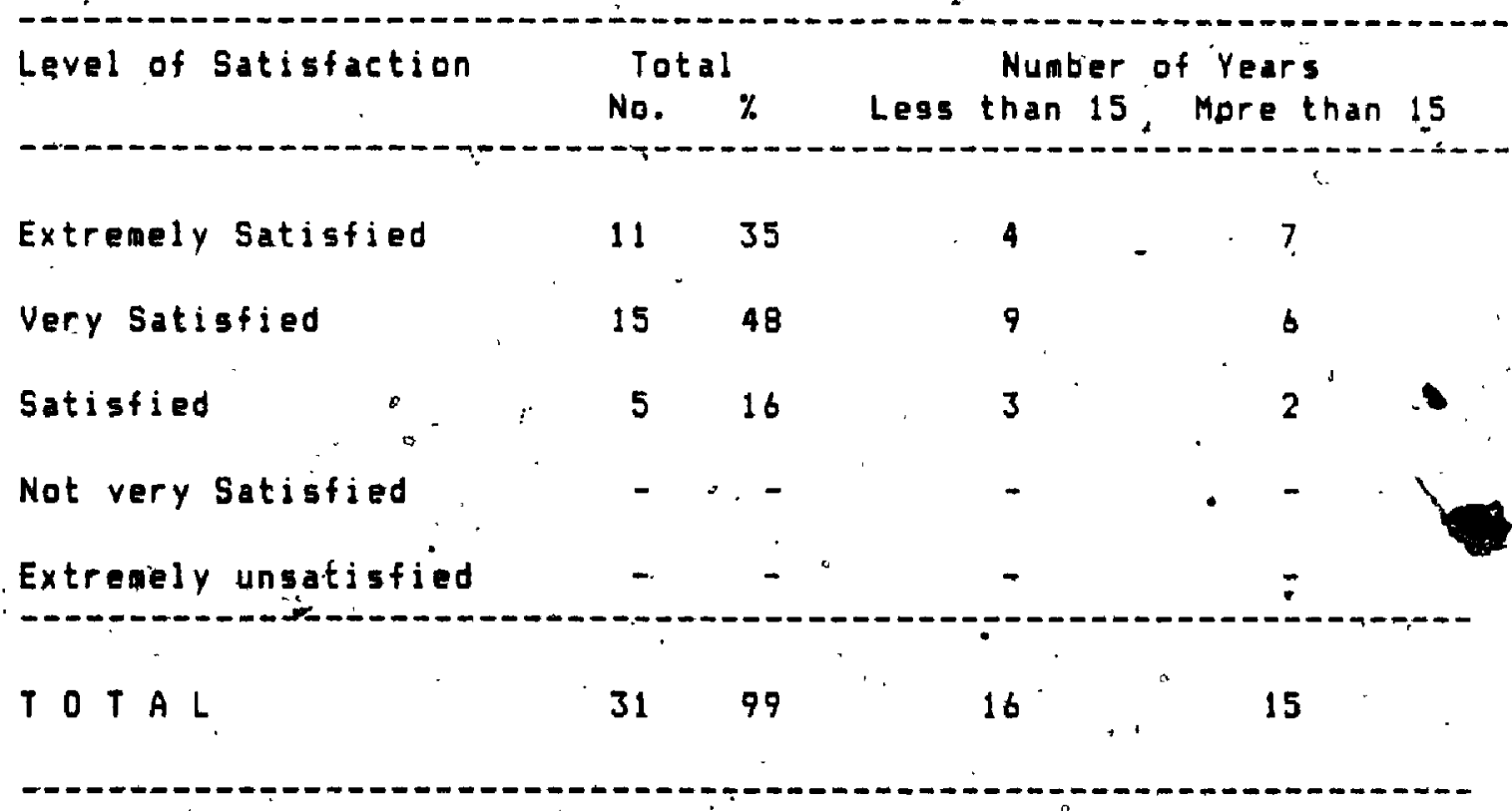

Source: Gưda, Sample Survey, Spanjsh Community; Ottawa 1985

About one-third of the sanple'claimed that they did not like the way Canadian people entertain themselvies. Most of the men: mentioned how they missed one typical entertainment in spains. "bares y tapas". Obviously in Spain people tend to go out aore often than here in Canada, where weather forces them to stay at - home, inside, afid also because the practices and habits are very different. This difference in ways of entertainaent was more frequently mentioned by men, no matter what the age, level of education or length of residence in Cariad. 
Some of the respondents al so" referred to the "oid fashioned" clothes at the time of their arrival compared to the more wodern and European Spanish styles. Stilu they prefer to buy elothes in spain if they go there to visit. This aspect concerned with personal appearance, has bẹen studied by many authors; "Ippearance is sacred in Spain..."in (Martin, 1955; Diaz Plaja, $1970)$

The subjects in the sample were asked to talk. about the changes in thesr values and difficulties experienced after leaving. Spain. When traditional. Spanish families enigrated to Canada, by necessity, changes. in their fanily relations, schedules, food habits, values, ett. took place. All these traditfonal vilues and habits were affected by the immigration processi generallý cjrcumstances and new demands in the host society made then change and adapt some of "their values and practices to the new conditions. Approximately $29 \%$ of the total sample did, not adinit any change since their arrival to Canada, but there is evidence of some changes and acculturation to the host society, especially related to child raising. Mothers did not seem to find it difficult to raise thejr children in canada although they recognize the existence of different values and methods; howe er from data gathered in the interviews it appears that there is very little conflict of values or generatianal

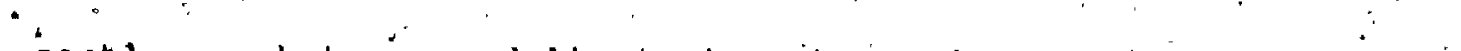
problems between, adult imagrarits and second (or third) generation children. According to then they havertried to be "less rigid but not as liberal as Canadians are with their 
childrens, the amortant thing is to isnd a balanca betwe ten the two cultures...". Lespite atew cmanges or adjustant in the Sparish tandies, tambly or kinties arastild of parauount iagortance, itimily obligations, patriarehy, privileqed position of the chiloren always under supervisuon, among othersi. It has to be noteo that fapily strueture in 5pasnstill remasns more conesive than in any other weatern Europe country, Morth America and even Latın Haerica IMuñoz, 19741 .

Unlike the tinolngs by several scholare concerning the Increasing. participation ot imagrantenen in child care and generai dometsc tasks (Brettell and Da Rosa, 1984; Munoz, 19721, in our sample very few of the Soanish men performed domietic tasks. Unly in three (3) housetiolds did the husband share soie responsibilities in the nousei. in the rest of thea, the reasons tor not particapating weres." lack of time, and siaply thiat spanisen men are not accustomed to do domestic labour. The relations. between sexes among this group are stll nonegalitarian. Inere is a strong patriachal iarital relationship. In general a nusbandidosinant, fiteisubordinate ṕatern was goserved in spanish taillies, that maybe has been product or dominant iatholic church values.

inose: responoents who had previous inimigration experiences betore-coming to canada are wales whose adaptation to the host country appears to nave been easier, especially in. teras of accolturation; they, tend to nave haghor codiua level of 
acculturation, and they declared that the "cultural shock" occured most frequently in their first country of immigration.

Discrimination was not an aspect mentioned spontaneously when talking about satisfaction with life in Canada. Some of the respondents mentioned the existence of some kind of - discrimination, although this as not "open". Our resulds contradict Sacco's fandings in Quebec (1958) when almost half of the sample referred to the discrimanation they had felt. Maybe after 27 years of increasing immigration to Canada, Canadians have becone more accustomed to the presence of immigrants although there is still a "hidden" prejudice gr racism agajnst "foreigners". Also it could be said that maybe in Quebec, and also. Toronto, or western European countries such as France and Bermany, there is more discrimination than in ottawa as some of the respondents have stated (3). It has to be pointed out that Canadas population has grown as a consequence of natural increase and substantial, net pigration in the $19 t h$ and 20 th centuryi immigration policies have been primarily "manpower" policies, therefore jomigrants have played an important role in the labour force, facilititing econonic growth (Richmgnd, 1979). Nevertheless, there has been some opposition to jinaigration in goneral, especially in times of econonic crisis. Canadians do not, consideried themselves "racists", but the non-existence of real structural assinilation, especially in the case of e.q. south European, Asian and black ethnic groups proves that there is still somewhat of a "discrimination". against minority ethnic 
groups which makes their occupational or social nobility difficult, as well as their general adaptation to the host society. IPorter, 1965; Kalbach, '1970; Richmond, 1967, 1972; Turritin, 19791 ,

Only six individuals clain to have experienced discrimination in Canada, speciflcally Ottawa. It 15 interesting to note that the majority of males in the sample $(76 \%)$ do not thank there is discrimination of differential treatment towards .immigrants in Canada. Women point out that there is no discrimination but rather "jealous'y" from Cariadian people because Imojgrants may have achieved more economically than many Canadians.

In two cases, the existence of discrimination towards Spaniards, or. immigrants in general, at some universities was mentioned.

Another :possible indicator cf acculturation is the. immigrant's "wijlingness to adopt the host" society's food habits. It was faund that twelve of the Spanish households do not generally eat Spanish dishes; or cook Spanish-style meals, and they are core adapted to Canadiat food habits $170 \%$ or aore of their weekly meals are not Spanish). Eleven respondents declared their preference for mostly Spanish dishes in their aeals. Approximately eight of the households try to maintain an intermediate elaboration of Spanish-Canadian meals. There is. 
tendency to mastain typical spanish food primarily because the 4. males (husband) in the nousehold prefer it. Women are more elastic and consider Ćanadian meals more practical, easier to prepare, also their children like then, but they generally have to make Spanish dishes because of the men's demands.

There does not seem to be a higher adoption rate of the diet and foods of the host society with increase in the length of residerice.

\section{IABLE_ 4.13}

Fogd_Habits _of the Sangl

$\begin{array}{lll}\text { Food Habits } & \text { Letal than More than } \\ \text { No. } \% & 15 \text { years. } 15 \text { years }\end{array}$

Mainly Spanish Food Habits

1135

4 7

Mixed Spanish-Canadian 8.26 4:

Low Spanish Food Mabits 10. 32

8 4. Very Low Spanish food Habits (mainly Canadian) $2 \cdot 6$

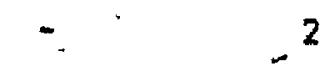

T O T. A L

31100

16

15

2

2

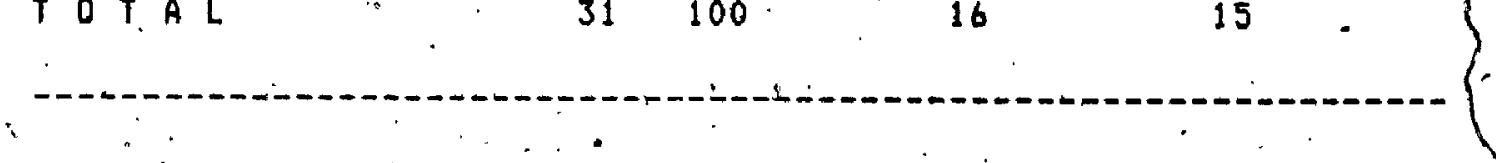

:

Source: Guada, Sample Survey, Spanish Community, Ottawa 1985 
IAE $\underline{E} \underline{E}-\underline{4}-\underline{1} \underline{4}$

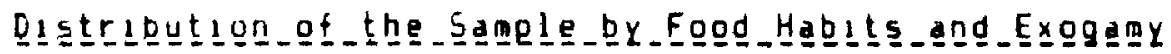

Food Habits

Malnily Spanjsh

. Food Habits

$11 \cdot 35$

941

2

22

$M 1 \times e d(50 \%-50 \%)$

826

b 2

27

2

22

Low Spanish Food

Habits

$10 \quad 32$

6

27

4

44

Very Low Spanish

Food Hablts.

2.6

15

11.

TO IA L

31100.

22100

9. 100

Source: Guada, Samplé Survey, Spanash Communaty, Ottawa.1985

There appears to be a dafference when taking anto account it the respiondents were married or not whthin their ethnic group. There is a tendency to abandon Spanish diet and food hab.its. with exogany and in this case even more so beciause there are more males (o) than females (3) married to non-spansth, and generally the non-spanish women are those who cook or decide in this respect. 
Data afput legal status or eitizenship of Spanish immigrants was collected in our study, not because we think it is a sign of acculturation but to find out their opinions about this issue. Two-thirds of the respondents are Canadian citizens. This represents a high proportion when compared to other south European groups such as portuguese and Greeks (Chinbos, 1980; Alpalhao and Da Rosa, 1980). The reasons why they became citizens were manly of präctical type, that is, for the possibjlities that citizenship opened up for jobs in the public service in addition to the general advantages such as social gecurity, having more rights, and related to travelling abroad, especially to the United States. There are: few differences in this respect between males and females.

$\because$ The ones who have not decided to apply for their canadian citizenship claimed that they did not need it and it did not represent any advantage to them. It has to be pointed out that Spanish citizeristip is not lost with the acquisition of Canadian citizenship (as in earlier years), but there are still a few individuals who believe this and emphasize: "I will always be Spanish until j die...". Of those who have only Spanish citizenship, more than half are think!ng about becoming Canadian in the future, if they have to, in order to work in the public service and also because of their children. Some of the respondents in the sample were not qualified to make applications, prinarily dae to. linjtations of language ability. For others life in canada has been very acceptable without having taken out = Canadian citizenship. 
IV. ETHNIC ATTACHMENT

Another factor deemed to be important in the study of the adaptation of any imaigrant group are their ethnic ties and involvenent in organizations of their "cominuitas" (Ereton,1964; Porter, 1965; Rogg, 1974; Weinfield, 1981). The social structure of the spanish comaunity was deseribed in Chapter Three, and in general how ethnic ties are maintained. In thas study we have considered various aspects of ethnic attachment such as promary groups, affiliations, participation in ethnic institutions, lmage of homeland and use of ethric services and media.

The preference for friends from theit own and other closelyrelated groups, as the interviewees declared, is the feeling of being confortable with people who have the same customs, traditions and janquages; there is a better understanding and more sharing than with members of the host society. The very few - indjujuals. Who admitted having a majority of Canadian friends, claimed that Canadians were mope sincere, less hypocritical and more educated than the majority of Spaniards here in ottawa. It is important to point qut that these individuals (two males and one female) are either married outside of their ethnic group or have a high level of education.

There were a few cases when it was difficult to obtain the three best friends; they claimed to have more acquaintinces than friends because they preferred to relate primarily with their relatives (extended kin): Of 18 individuals who have relatives 
in Canada, six $(33 \%)$ have at least three"relatives in ottawa whom they see very frequently, weekly or every two weeks. The contact with best friends in half of the cases was bi-weekly or less frequent, mainly because they are busy during the week. In the case of women they expressed the need to see their best friends at least once a week. Contacts by telephone were more often (dajly or at least two or three times a week), particularly - amorig females.

In 26 of the 31 cases of the sample, the personal relations - of Spanjesh immagrants are within their own ethnic group iall three best friends, or at deast onel; the other five persons have a majority of their social ties outside ethnic group social networks lCanadians or other ethnic groupst.

ALthough more than four out of five replied that at least one of their best friends was of thejr awn ethnic group, only one In five said that all of their three closest friends were Spanjsh. It it interesting to note the high informal interaction 'with Hispanic American people, especially from Argentina, Mexico, Venezuela, chile, and to a lesser extent, with Italians and Portuguese. As we have observed before, Latin Anericans also participate in some of the Spanish associations. It is the ales who seem to associate more "frequently with Canadians than temales, majnly because they are more acculturated and generally have a higher level of education and "openly" admitted that they do not want any relationship with their own group members; or else they are married to non-spanish wives. 
IHELEE $4 . \perp$ ?

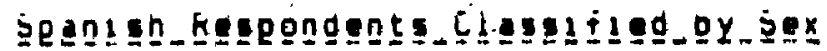

and Ethnic orig1n ot lne1r best Erienge

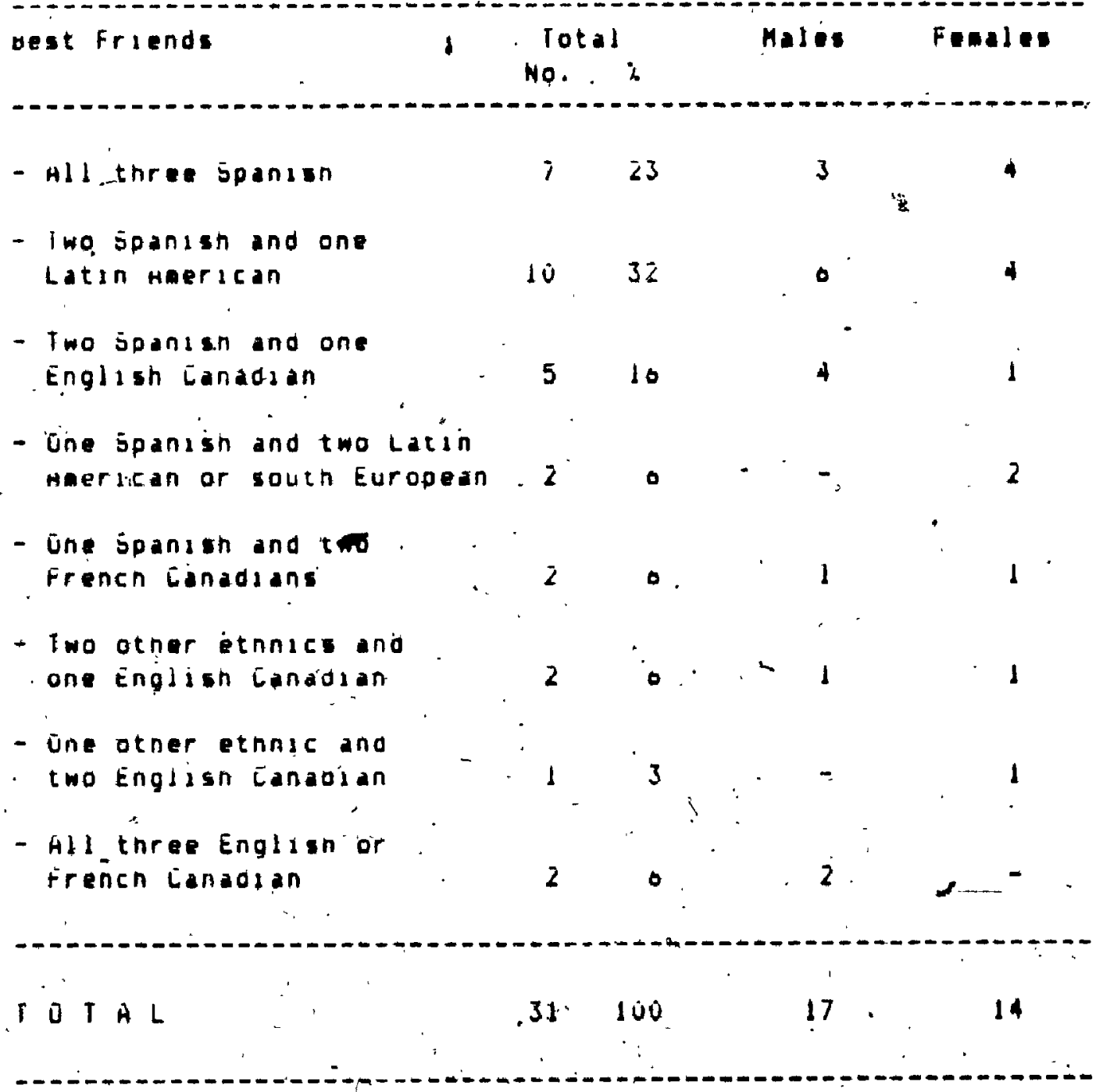

Source: Guada, Sample Survey, Spanish Cosmunity, Ottawa 1985

Three in tive of the simple may be considered an interaediate graup which interacts wath both menbers and noneenoers ot this ethnic group. "Ihis "discrepant" positson. as hold by what Restz has called "peripheral mabers". (1980,1113). 
At a secondary level it was observad that those who did not mention Canadian or members of non-south Eutopean or non-Spanishspeaking ethnic groups as best friends, didhention those groups as acquaintances: e.g. neighbours, workmates, mainly nonaffective or intioate relationships. This may be a consequence of alightly different interpretation of the word "friends".

Analysing interpersonal relations by length of residence in Canada we may say that in this study ties with native people do not necessarily increase, contrary to what Breton found in him study about institutional completeness and the personal relations of inmigrants. He argued that it "is after six years in the host cquntry that the, ties with the native community show 'a substantial inçrease" (1964:197). Maybe oṭher aspects; e.g. - English-french language skills; size. of group, have noreinfluence in having or not having relations qutside the ethnic group, than years of residence.

The minority who declared having very few or no spanish friends argued that Spaniards here in ottawa are "gossipers; envious, pretentious, and always eriticizing each other". It should not be forgotten that Spanish imaigrants as is the case with. other ethnic groups are not necessarily homogeneous groups. and that a person can identify with sque subgroups and not with others. Social class is an important factorito be taken into account. 


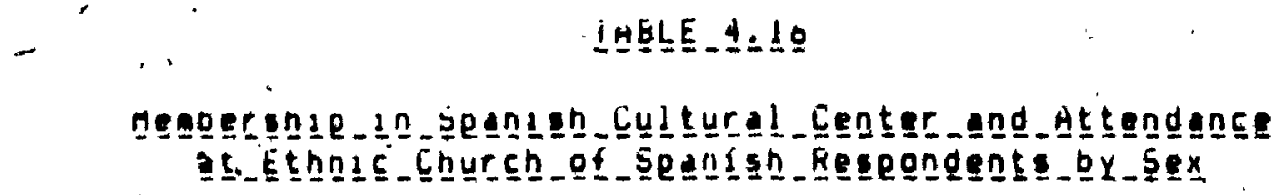

at Ethnic_Church_of SednIsh Fegeondents bx_5ex

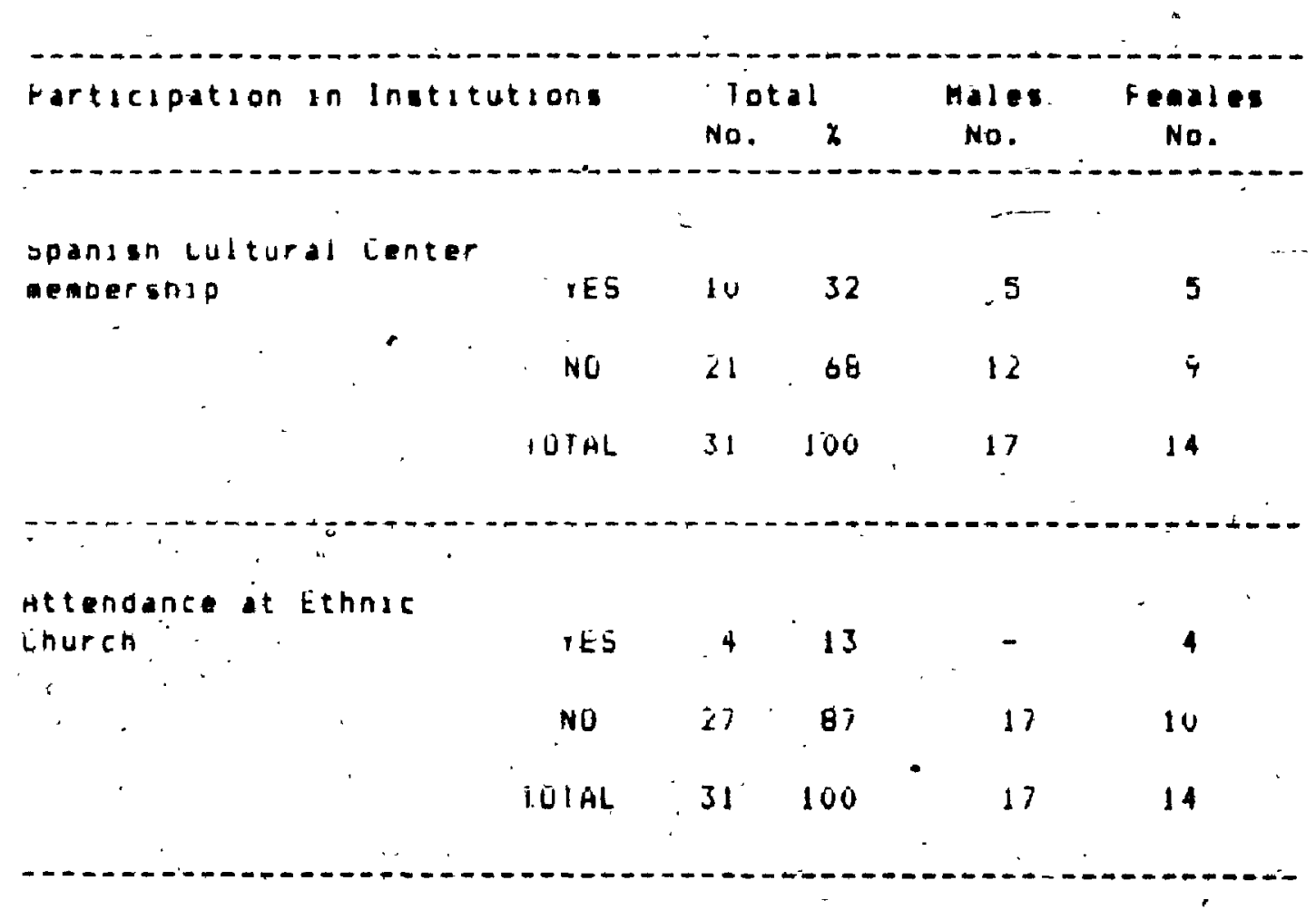

source: buada, Sample Survey, Spanish Community, Ottama 1985

Although the membership at the Spansef Cültural Center as low and only triree males and two tamales partactpate actively. limost all-responoents have attended sone activaties organized by this assocjation in the past, parties and other plebrations, or do so at present because the activities also include nonmembers. some interviewees have dropped their menbership because of dislluspongent for any reasons, e.g. disagrement with the organszation, "clashes caong iembers, or not doteristed in the type of activities promoted. 
According to Breton (1964), the higher the institutional completeness of a group the higher the degree of ethnic relationships at a primary level. But in our case it appears that despite the low institutional completeness of the Spanjoh innigrant group ("community"), the majority of the relations at a prinary level are within their own ethnic group. The spañisti ethnic group in Ottawa as in the case of the Quebec community in 1958 (Sacco, 1958) has a weak social organization (only one educationar, one religious, and one sociocultural organization); therefore there is less frequency of contact, hence less opportunity to reinforce its ettnic identity and ancestral language. Nevertheless, the number of formal organizations per se may not be so important because this ethnic group is too 5 all to warrant an elaborate organizational structure; even if the majorjty of their members participated in the existent organizations they would still be small, but may be stronger as a conounity, identifying more" with their country of origin. Our findings suggest that there is a low proportion of Spanish immigrants in otfawa who participate (specialiy as members) in institutionws which would norally reinforce communal life and the group's culture or folklore. As we have observed earlier, memberstip in the Spanish Cultural Center (Centro. Español) is not more than $40 \%$ of the total Spanish immigrants in Ottawa, and on the other hand the average number of then who regularly participate in the religious activities "is also very 10w. 'This study seens to confira the reported low participation rate (Table 4.16). 
Church attendanee as noted arlier, is generally poor and sporadic. Nevertheless, a small nupber (6) admitted their participation in the past. Those who havenever gone to : religious celebration. stated that the present location of the church is too far from their present homes or they preferred to attend English or French religious services. It should be noted that majority of the respondents were Roman Catholics although not all of them were practising.

The other institution, the Ethnic school, has been or presently is being attended by two-thirds of the total hougeholds in the sample who had children (21). These children come mostly from homes where the spanish language is used regularly. When parents were asked about the reasons for sending or having their' children sent to this saturday school, they all agreed on the need for the young to learn their parents. Ianguage, especially to write it, because when the majority of then started attending that school, they already spoke the language at home. Also mentioned was the importance of parochial education for the perpetuation óf. the Spanish culture in ottawa.

On the other hand, one in five of the fanilies with children appear to have a ngative opjnion about the school. They claimed that they only sent their children there for a. shopt time because "they dio not lejern phything there"; others mentioned the difficulties in sending children on Saturdays because the childien were too tired, too old, not interesteph or thi school 
was too far 'from home. A few females claimed that the school was "not very well organjzed".

Although it goes peyond the scope of this thesis to determine how strong religious values are for spanish immigrants, it has to be pointed out that there is not an apparent preference for Separate ('Catholic schools) in the households with children.' Almost half of these households have selected the Public schools (non-Catholic). The other half preferred the Catholic Board of. Education schools and only one fanjly sent their. children to a private school. Sometimes they"send children to Catholic schools. becalse they are nean their homes.

To complete these observations about participation in the various. Spanish institutajons, the contact of the Spanish. - inmigrants with the Embassy in ottawa mainly refers to only one celebration that is organized annually in June (the King's Saint Dayj. Even the more isolated individuals ifrom the ethnit connunity), that is, those who definitely reject associations with other Spaniards, attend this activity.

Only a small proportion of respondents attended other Spanish janguage cultural activities itheatre, films, dances, conferences, etc.) that the. Eqbassy, the Spanish Cultural center, and Spanish Departments at the universities organize on certain ócrasions. 
In the same onner that participation in ethnite institutions is Jow, because of the "instinctive animosity of spaniards to participate in associations" 10az Plaja, 1974:57), the utilization of the few ethnic services existing in ottana for the Spanish ethnic group, is also low with the exception of medacal servirss. This is considered a major service that most of the inmigrants eventually sequare, and not because of loyalties or cultural preference but the language problem forces approxinately two out. of everye five of then to seek out spanish-speaking doctors, especially a Spanish doctor, and a Frenich Canadian who speaks Spanish. Very few people mentioned the use of other ethnic services:, hajroressers (2), travel agency (2), garages (2), howe repajrs (2), bookstores (3), Montreal bookstore (4).

Most. of the respondents shop at non-spanish stores (groceries,etc.) because there are no spanish estáblishments here in Ottawa. When they need Spanish specialties they shop at other South European stores, namely Portuguese and Italian, or in Montreal, where there is a large establishment. ILibreria Española) with a wide supply of Spanish (and also Latin American) foodstuffs, books, and records, among other things.

With respect to spanish newspapers or agazines Ifrom Spain or edited in Torogto or Montreall, there are very few individuals $\therefore$ who frequently buy and read the (three females ind one dale), or have subscriptions to "El Pajs", "Combio 16" and "ABC": The Werest of the respondents read ethnic media very sporadicaliy when 


\section{$-115-$}

comeone lends it to tnem. Men teno to bo more interested in

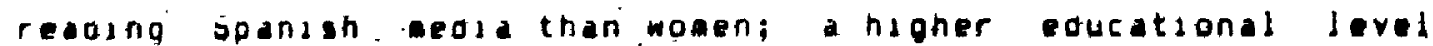
seens to be another factor that motivates the need for intormation trom the nomeland. The reasons given tor not buysng or reading ethnic aedia are mainly lack of time, difilculty in ootalning.thea, or simply lack ot interest. It has to be sad here that only half (50\%) of the temales in our sample read the Lanadian. English or french, press, compared to a higher percentage ot males $(71 \%)$. Those who tiend to have more access to the ethnic aedia ifrequency of lecture and nuaber of newspapers and. agazinesi also tend to be better intoraed through the mase weda ot the wider society, and sometiaes internafional. With respect to Spanish television programes inultetilturalisar, very tew people in our samplewatch thea theydo not seem very interested in thas etnnic activity.

möst 0. the ippanish langiants, siaslar to other foresgn etnnic groups, mise trieir country of orsqin, althougn they very

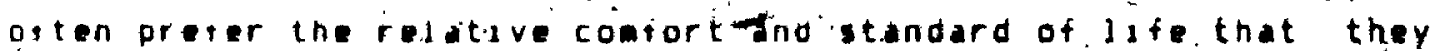
have chquaged nere in Canada. Ineretore, they contanuously delay their inal departure or returi, establishing inew god s. and supplementary acqussitions-to their originat plans when they left spain. Inrs asoect or pattern has also.been conicired in the

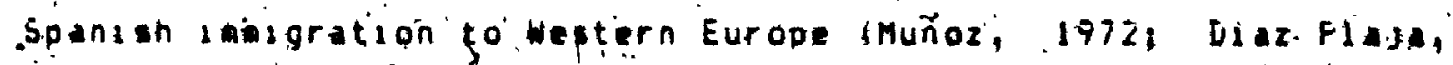
1974). According to Murioz, "the hope of returning home and the anxiety acreated oby a ney start, leads to psychological

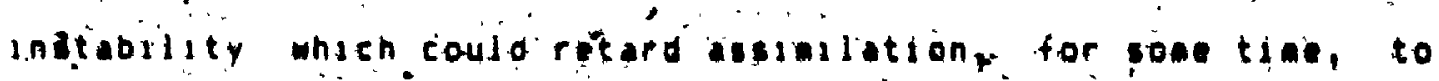
the nost cacigty" $197 \overline{7}$ iloij.. 
Hiost one halt ot the individuals in the sample oo not expect to. return to jpain to daves they antend to stay an canada, specifically in Ottawa. OnIy six respondente expressed their intentions of returning to thesr homeiand in the near future. In addition. Slightly less than a thirdare uncertain about this decisionf they would like to live annually six monthe here in Canada and six monthe in 5pan. In tew cases they untend to move to another country in the tuture, e.g: United States, or rortugal.

In spite ot this tendency to stay in canada, which could be considered positively related-to acculturation and adaptation in general (Bottonley,1981:29), there are strong "nostalode" senti= aents about Spain. : Almost all tre respondents wo stated that infer would stay in canada because ot the family chusband and childreni also anitested their desire to go back to $5 p a i n$ is they could.

Females are especially concerned about their children, who were elther born in Canada or came nere when very young. Theretóre, they consider thesr return to spasn viéry unreabistac because there are more oportunites tor thesr chilaren in canaos ithan in jpain. It was also mentioned that they would lose their .010 age pensions, Insufances and atner bengfits they have built up it ther leave iandoa. 
The ideal solution apparontly is to live between the countries so that they would have the best of Canada and Spain at the same time. Further research is need on the return_tongomeland data for Spanish immigrants in Canada and how their readaptation occurs. This aspect has been already studjed by sone authors interested in the Spanish immigration to Western Europe (Diaz Plaja, 1974; Pascal, 1969).

There is a relationship between the idea to return to the country of origin and occupational status. For Marziale ceited in Muñoz, 1972) and Krane (1974) the most highiy skilled, better or more effacient workers are usually the ones who.have the least - intention "of returning, to Spain. With the data avajlable we could not confirm this assumption, although we presume that no matter how low thej occupationaj position is le.g. service occupations), they tend to stay in Canada beiause of their better standard of living and better opportunities for the children.

When asked about their readaptation to Spain oin case they: return one day; men $(59 \%)^{\circ}$ tended to be more optjaistic with respect to the ida of eventually returning home: for then it would be very easy to adapt to spain again. Women are more dubious about the readaptation, only four think that there would be no probleas. Most of 'the fenales' in the sample refer to how difficult and different the way of life is in spain compared to the way of life and standard of jiving they have in canada. The only factor that mould make things easier to live aquin in spain 
would be having money, and even then, they will wiss how they lived here in Canada, especially with respect to material confort.

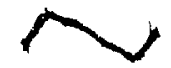

When discussing the possible readaptation to life in spain if they returned in the future, the interviewees indicated a sizeable numer of negative aspects of life in Spain lTable 4.17). It appears that there are more disadavantages or negative aspects (e.g. low standard of living, insecurity, etc.) that the individuals in our sample mentioned, compared to what they niss or considered positive aspects in their country of origin.

While this may be so, of particular interest here is the extensive conmunication and frequent travelling of Spanish immigrants in ottawa to their homeland. This coincides-with the pattern of ties with the country of orjgin of other southern. European groups, specially Portuguese (Alpalhao and Da Rosa, 1980; Anderson and Higgs, 1976; Moskos, 1980; Chimbos, 1980).

The perceptions of an ethnic group are antluenced by the ties with the homeland, Spain is more readily accessible from - Western . European countries fFrance, SwitzerlaAd, Germany, England? than from Canada for example. Nevertheless Spanish inmigrants in Canada tend to travel to Spain ạt least once every two or threge years. Considering the length of residence in Canada, it can be said that the iverage number of years in Canada for this sample was 15 , and the proportion of those travelling tend to increase slightly with the number of years in Canada: 
Negative_Aspects of Spain_for_a_Samgle_of

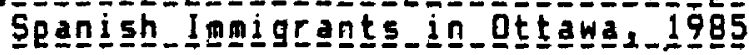

Negative Aspects

$-$

Disorganization, chaos, anarehy

Informality, impunctuality,irresponsibility

Low standard of living, poverty,

backwardness, fewer jabs

Gossip, "que diran"

Influences, politics

Insecurity, drugs, delinquency

Dirtiness, garbage, bad services in general

Individualism; hypocrisy; vanity

Noise and loudness

* more than one answer

Source: Guada, Sample survey, Spanish Community. Ottawa 1985
Total

No. $\%$

$8 \quad 15$

$7 \quad 13$

$7 \cdot 13$

$6 \quad 12$

612.

5. 10

$6 \quad 12$

$5 \quad 10$

24

$52 * 100$ 
conversations with parents and even with children, it was observed that children enjoy visiting spajn lbecause of the weather, family and friends), and sometimes they are sent there during the summer to practise and study their. spanish.

In two cases respondents travelled to spain more than once a year for work-related reasons; that is, their work nade. It necessary to go to spain because of business interestsa a professional small entrepreneur and a University professor.

With very few exceptions it would appear that the reasons for visiting spain are related to the desire to keep ties with the extended family, although triis may not be their exclusive motive. They try to combine it with holidays and recreational purposes as well. There are five respondents who declared that - they did not have any relatives left in Spain, therefore they just go to visit friends, and visit as tourist to places in Spain they do not know, or else they go to other parts of Europe and stay for a very short time in Spain.

For about one-half of the sample the way of life in $5 p a n$ is more "humane, entertaining, slower, joyful" than here in canada. They mentioned that despite the better standard of living and. their econoeic advancenent in Canada, there is no "soie de vivre" (alegria de vivir) compared to spain. They appear to have an. idealized image of their country of origin: fanily life, peace, holidars, rest, nice weattier, etc. This image tends to continue. 


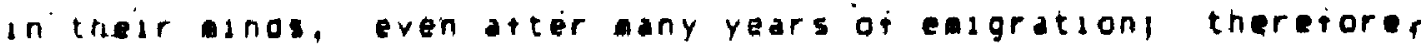
they orean of returning, aithougn they often have to postpone these plans or one reason or anotner. This same pattern ls also reported of Spanish inalgrants la western Europe lGarmenda, 19701 Munoz, 19721 as well as of other south European groups lchabos, 1980: Nagata, 197vi Anderson and Hag9s, 1976).

we have alfeadyonoted the paucicy of their own institutaons in the spanish cosmunty in Ottawa, as well as thelr jow rate of particioation in activities of those which do exist. Nevertheless, wost of their closest frienos arewithin their own group. Inls may oe explasnedby the tendency ot 5panish people tor non-" colbective actions, and may be a retlection ot thelr overemponsized inoividuailsa. For about halt ot the sample, the spanisn comainity of Dttama ls not a "ireal communsty" mheré. memoers collaborate witn each other and unite for the defence or their interests. These respondents mentioneo the rivalries and clashes existing oetween, individuals or ialilies. For otners i1\%\%, there is a. comanity, but it is divided into saall groups who share common interests, and characteristics such as age, time ot arrival ano sometimes regions of origin in 5pain, Et...

üjy seven. respondent thank there is a "real" Spanish communaty in uttawa wrere consengus exists and conmonality. of interests are sharedi to glve examples oi this. unity ther toferred to help oitered to new arriyals kith respect to housingi loos and also norat support and. irlendinip. 
For the najority of people in the sample, the first contact with the Spanish ethnic group in Ottawa was the Spanish Cultural Center, but also some of them claimed that they did not like the Center, therefore they participated neither in the recreational elub nor in the chureh activities. It appears that, in general, the Spanish community in Dttawa does not always provide psychological and sociological shelter or milieu for the newcomer, and his or her needs. Sacco (1958) has referred to the rivalries, jealousy and clashes because of individual differences at institutions or organizations of this type. Rivalries also have been observed in almost all Spanish communities, not only in Craada (Anderson, 1977; Fernandez, 1972), but also in Western Europe (Diaz Plaja, 1974; Muñoz, 1972). This divisiveness is also typical of other south European groups in Canada such as Greeks and Italians (Chimbos, 1980; Hughes and Kallen, 1974).

Although regionalism (i.e. region of origin) has been mentioned as a reason for cleavages in other studjes about various ethnic groups and also the few existing about spaniards (Anderson,1977; Fernandez, 1972; Sacco, 1958; Ariderson and Haggs, 1976; Chimbos, 1980), in this specific research it did not seem to be a cause for clashes, at least it was not "openly" expressed by the respondents. Nevertheless. small groups do tend to associate with other immigrants from the same region, especially in the case of Gallegos, Asturians and Andaluces. 
Anderson (1974) believes that the larger the community, the more rivalries, the greater the independence and the more organizations that are formed. According to this assumption, the spanish community in ottawa should be united, but as argued earlier even in this small group there are differences, especially" in terms of social class, as reflected by their heterogeneous occupational and educational levels. It appears that those Spanish immigrants who seem to have adjusted most easily to the new society in terms of occupation and other adaptations seemed not to have used the communa base of the Spanjsh in ottawa for their injtial adjustment and further adaptation to the wider society, and they do not partici-pate in ethrac institutions nor use the existent services.

The reputation for individualism and rebelliousness of 11 iousness of Spaniards may be due to the great difficulties encountered in earlier times in developing a sense of unity and cooperation among the varjous groups and regions into which the spanish society of (Spain has long been divided (Payne, 1967).

$\checkmark$ SUMMARY: LEVELS OF OCCUPATIONAL ADJUSTMENT, ACCULTURATION - AND ETHNIC ATTACHMENT

Before entering the field we established indicators of occupational adjustment, acculturation and ethnic attachaent in our research proposal. For occupational adjustment it was considered that five items already used by Reynolds (1935), Rogis. (1974); Chimbos 11980 ) and Richmond and Verma (1977.) would measure economic adaptation. But after the collection of the 
data, it was realized that some of these itens, such as periods of time unemployed, change of jobs, and use of skills were not

- very relevant in the case of this ethnic group. To a certain extent this problea arose because of the sample size. Hence, we have attempted to provide a descriptive analysis of the data gathered and have summarized the information that we, on conceptual grounds, thought was relevant to an understanding of the three areas treated in the thesis: occupational adjustment, acculturation and ethnic attachment.

For the purposes of this study the basic, but not the only, aspects of occupational adjustment were: satisfaction with present job, occupational status in terms of the Blishen and McRoberts scale, and the fexistence of elements described an Gordon's definition:

The immigrant's successful relation to the secondary groups and instrumental institutional areas of American life which would permit him "to obtain and keep job commensurate with his petential and training, to receive the appropriate training and education where necessary". (1964:243) 
IABLE $-4 \div 1$ 旦

Level_of Occcyetitional_Adjustaght_of_a_Sanele

of_Seanish_lagigrants_in_ottawa__by_Sex**

Level Notal No.- Males Fenales

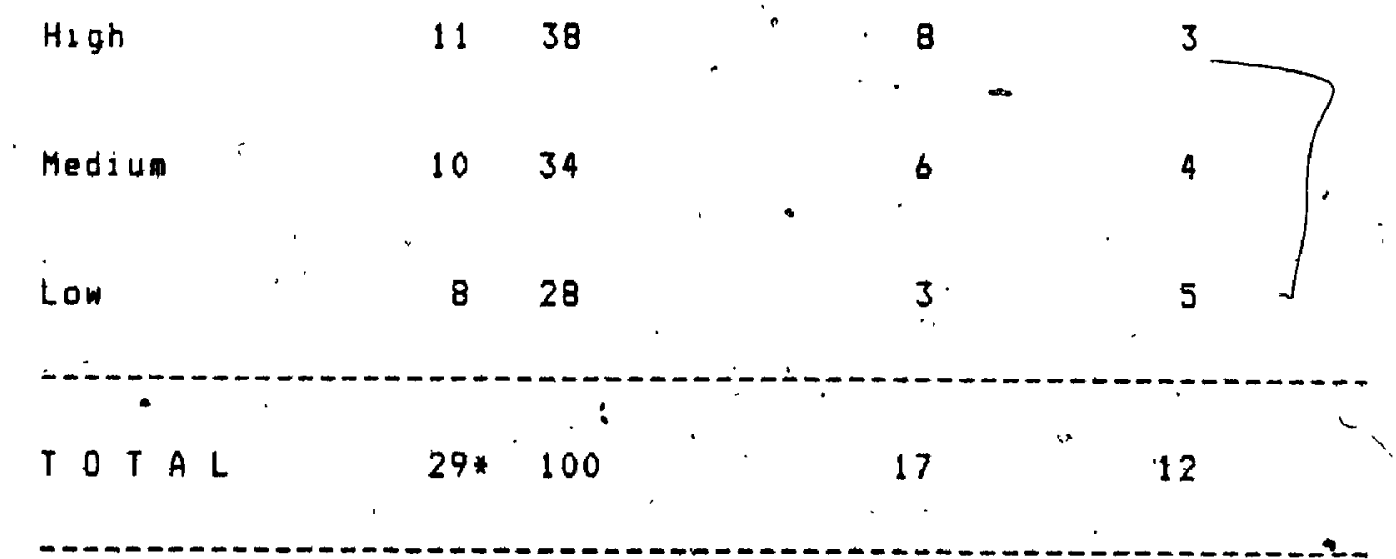

* Two femaleg are not working.

* As measured mainly by "Satisfaction with. job and present occupational status".

Source: Guada, Sample Survey, Spanish Community; Ottawal1985 


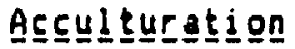

At the beginning of the research it was planned to measure the degree of acculturation*by three aspects; these measures mere borrowed trom others, Hurh and Kim (19.84); Rogg (1974) and Gordon (1964). The itens to be used were: ") host country language facility (in this case English andror French); 2) access and use of host country media; and 31 satisfaction with life in ottawa and/or in Canada.

Sinilar to what happened in the éstablishment of. the other iadexes, some changes were made: we eliminated the access to Canadian Mass Media and substituted it by the use of Canadian dietary habjtsi. although there has been some doubt about the importance, of this indicator in the process af acculturation. Reitz (1980addoy) has argued that curtural assimilation is different for: ethnic groups and difficult to compare. "One reason is that specific culturad items may appear more or less important to different observers. For exampje food as a cultural pattern. could be regarded by sone scholars as minor and unimportant, but others might not agree.v In the case of Italians, and all European. groups, traditional foods and cooking methods, are retajned long after other aspects of the inmigrant. culture are given up tGans, in Reitz, 1990al. But maybo Spaniards differ from Italians and other European groups, and traditionil food is less often retained. 


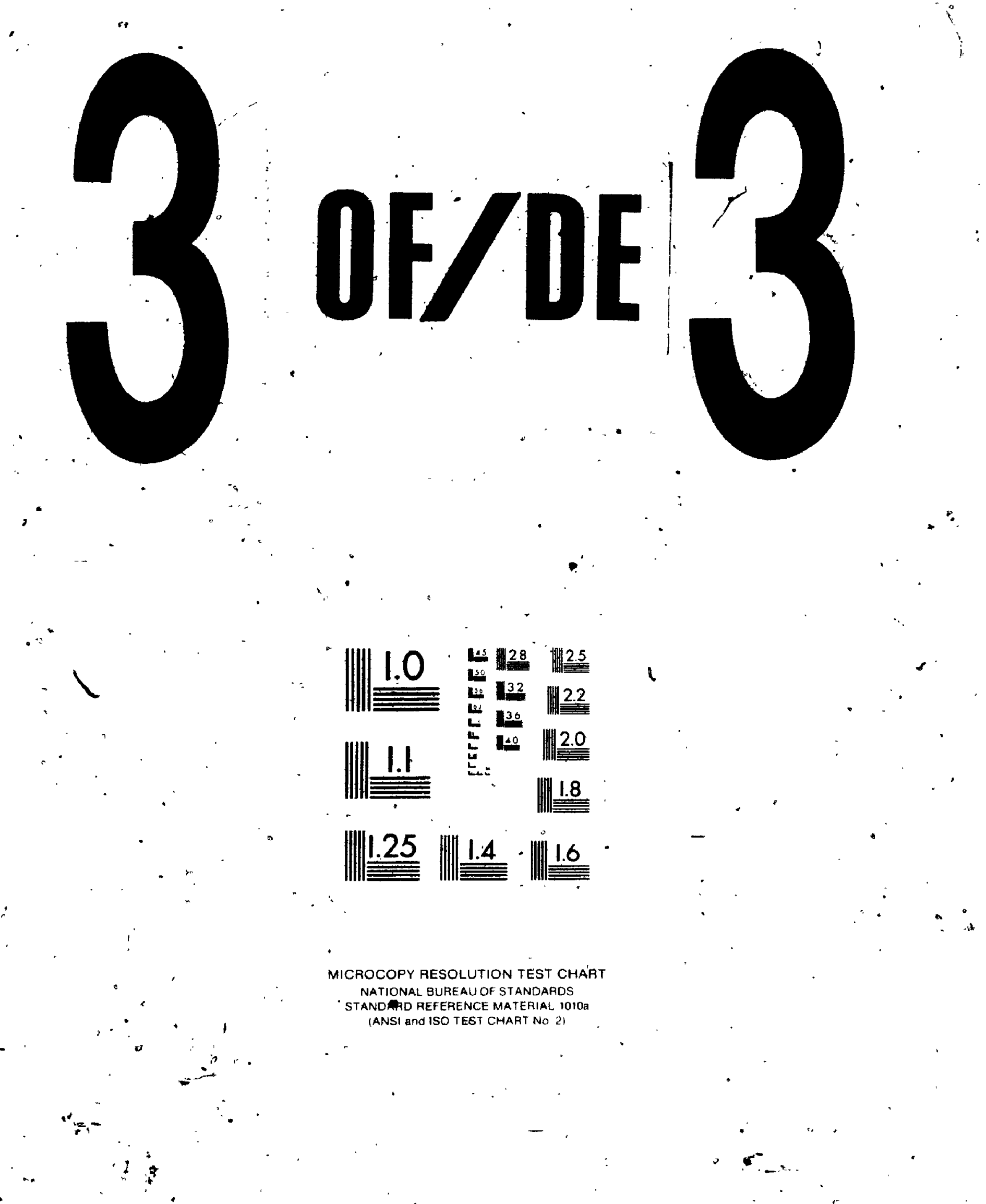


Another item introduced here was the intention to star in Canada:

a

IAB $-=E-4 \leq 19$

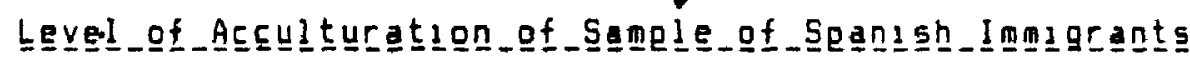

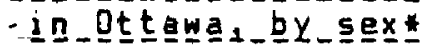
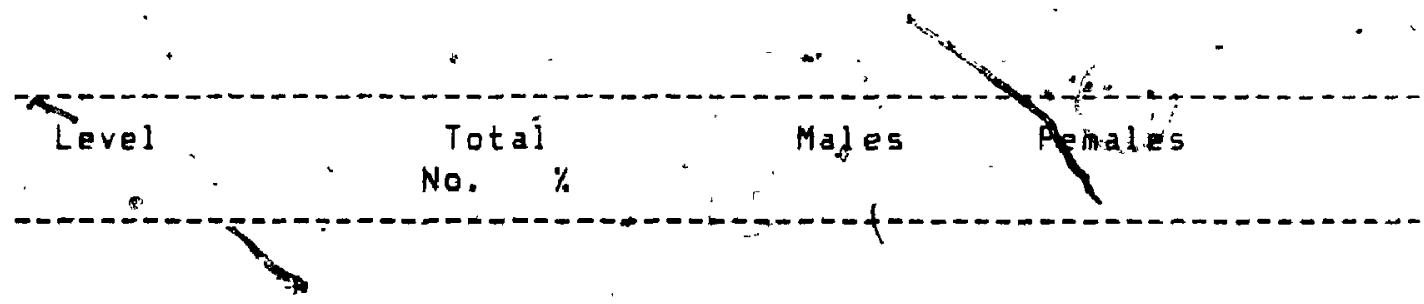

$\mathrm{High}$

$9 \quad 29$

6

3

Meds um

1

15

48

8

7

Low

$7 \quad 13$

3

4

T O T A L

31100

17

14

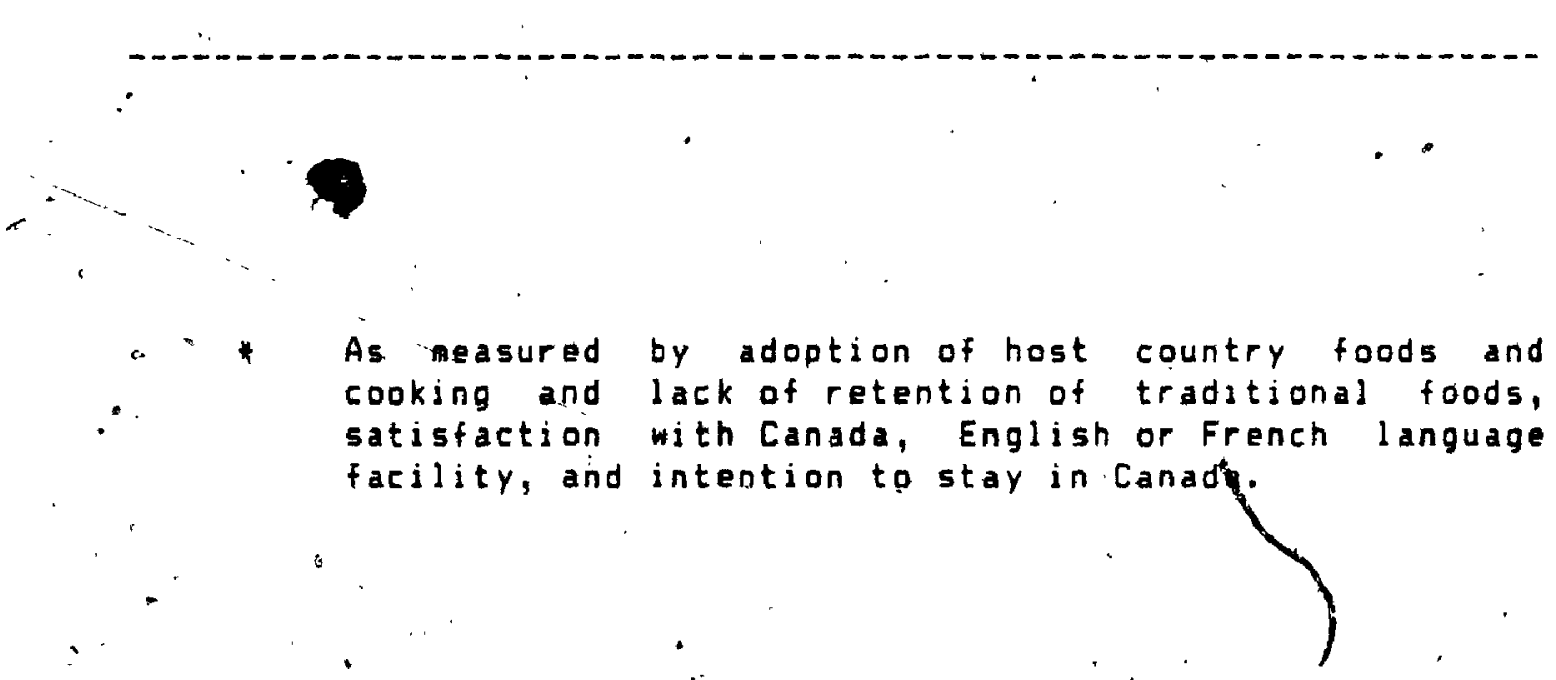

Söurce: Guada, Sample Survey, Spanish Community, Ottana 1985
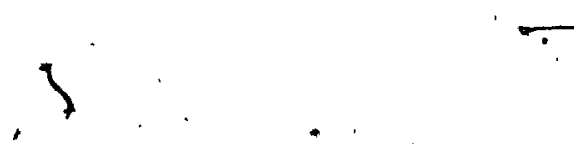


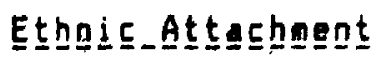

At the initial stage of this research ethnic-attachnent was operationalized by the adoption of several aspects used by other researchets. These were selected from previous studies such" as those by Sengstok 11978), Hưrh and Kim (1984), Rogg (1974); Weinfield (1981) and Reitz (197.4). Those items previously selected to determine the degree of ethnic attachment of Spanish immigrants in Ottawa were: (1) Jevel and/or continued use of । ethnic language (éspecially athome); 2) level of personal. relations. within.thejr ethnac group, 3) intention to return to homeland, 4) frequency of contacts with the homeland (travelling, mass media, etc.l, 5i participation in ethnic institutions, and .6) use of ethnic inedia. Again, it has to be pointed out the difficulty to develop a single ethnic "community tjes" index in our case without an elaborationd sophisticated analysis to determine, what aspects of ethnicity are more important than others, and our sample size precludes this type of analysis. To"." cate Reitz, "Ethnicity is a many-sided phenomenon; no one aspect captures alli, or even most, of its reality. Each aspect has a different relation to the other aspects... and for this reason.it is difficult to combine all of them in a single measure" (1980:117). Thus, out findings (Table 4.20) have to be taken carefully almoys pearing in aind that perhaps there are other aspects of ethnicity that are more relevant in the ethnic attachment of Spanish inmigrants than those selected in this istudy.

From the original itens proposed to measure ethnic ties, intention to return to the homeland and contact with ethnic media 
were discarded because in our opinion the contact hith ethnic media reflected pore the level of education or easy. access to it than an indication of ethnic attachment. Intention to return to homeland was used as an acculturation indrcator rather than of ethnic attachment, because no matter how strong ethnic ties are. for some individuals, they sometimes have to stay in Canada for $\varepsilon^{\circ} \cdot$ the reasons (financial, children, and others) already explained ( evider in this chapter.

- Instead of menbership $1 n^{\circ}$ ethnic associations Rer.se, level of participation in the activitas of the associations was used as aeasure of ethnic attachment (Table 4.20$)$. ,

IABLEE_4.2음

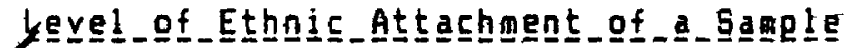

of Spanish_imgigrants.in_ottawas_by_sex*

\section{Level of Ethnic Attachment}

High

Mediun

Low
Total No.
Males

Females
9.29

$16 \quad 52$

$6 \quad 19$
4

8

5
5

8

1

T 0 T A L

$31^{*} 100$

17

14

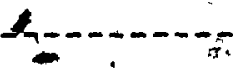

* As measured by use of ethnichanguage, personal relations, frequency of travelling and level of participation in ethnic assoriations

Sourcer Guada, Sample Survey, Spanish Community, Ottawa 1985 
Although after combining the different indexes we are unable to derive any definitive conclusions because of the small size of the sample, it is possible to observe some tendencies: for example, the highly occupationally adjusted individuals have a higher level of acculturation; those with a low level of occupational adjustiment tgnd to have a low or medium level of acculturation (Table 4.21$)$.

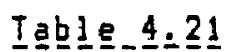

Dí 5 tr

DÉ

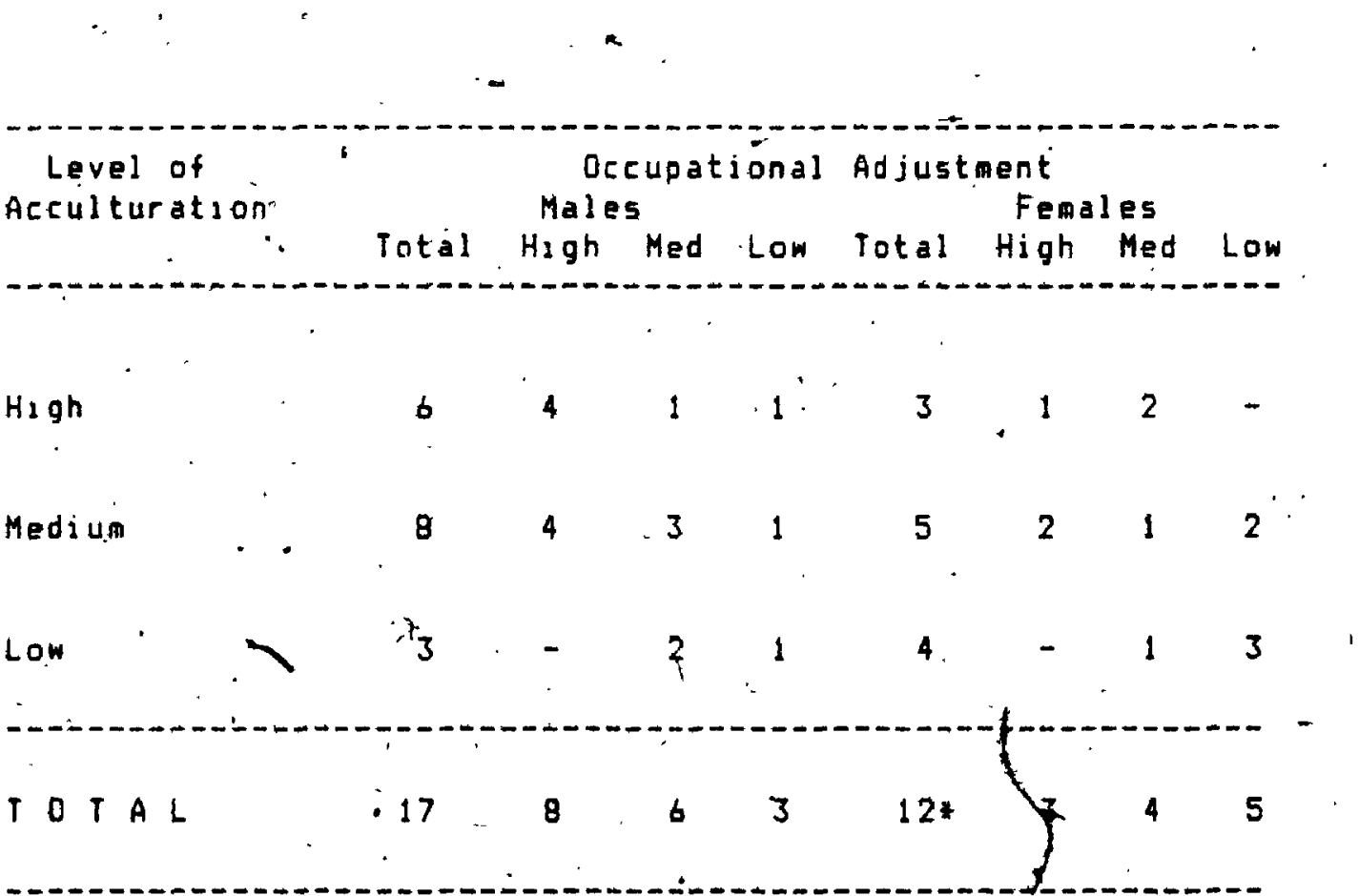

* Two tenales are not working.

Sources Guada, Sapple Survey, Spanish Coamuity, Ottawa 1985 C. 
It was observed that majes tend, in general, to hive higher levels of occupational adjustment and acculturation. They also have a high level of schooling, a different marital statug (majority are singles), and a better coamand of English or French. Length of residence does not appear to have much influence on the level of coccupational adjustment and acculturation of the respondents (Table 4.22).

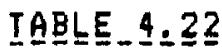

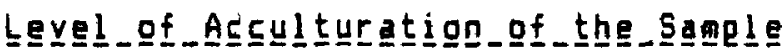

by SEx_and_Length of Residence

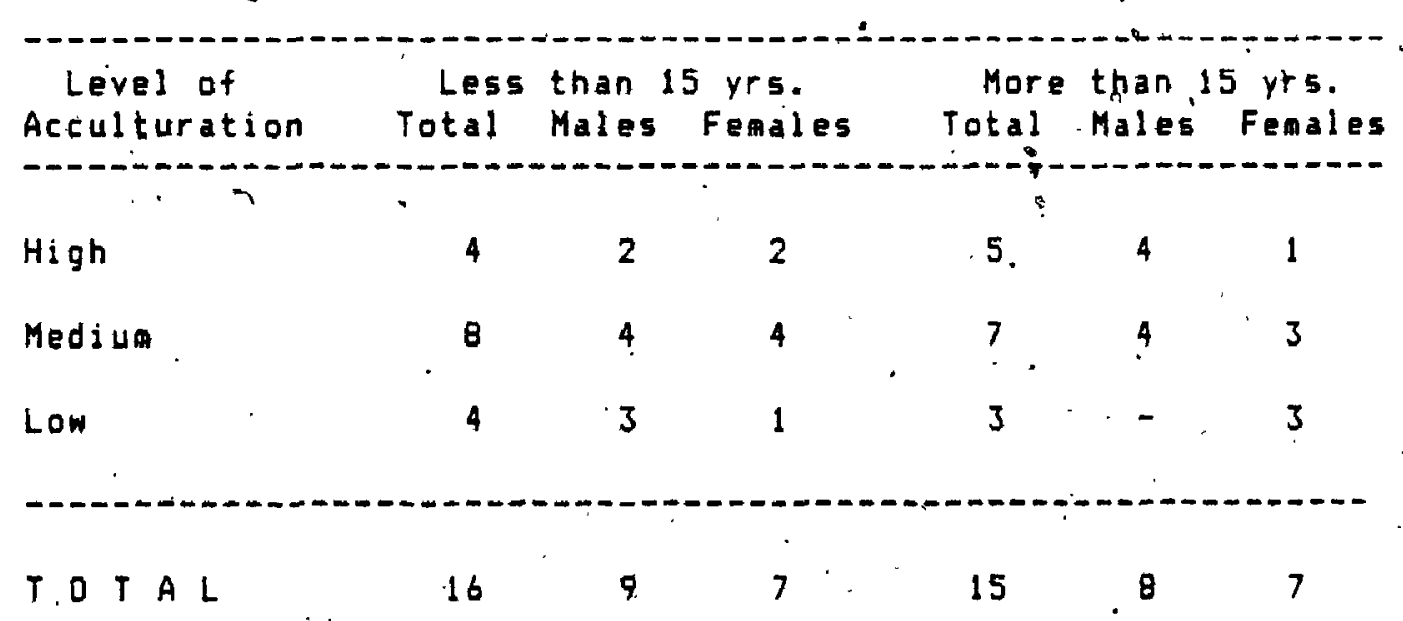

Source: Guada, Sample Survey, Spanish Community, Ottawa 1985

On the other hand, occupational adjustment seems to be inversely.related to ethnic attachment, especially in the cage of males. Females with a low leqvel of occupational adjustaent tend to have a strong ethnic attachaent (table 4.23$)$. 
IABLE_ 4.23

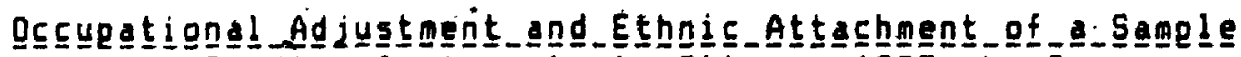
of Spatigh I

Ethnic Attachment

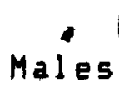

es

Total High Mediun Low

Adjustment

\section{Fewales}

Total High Mediun Low

\section{High}

MedI, U m

Low

TOTAL

\begin{abstract}
4
\end{abstract}

8

5

3

17

17

2

1

$$
4
$$

4

$1-3$

TOTAL

4

3

7

.2

$3 \quad 2$

1 in 1

1

63

12*

$\because$

- Two females do not. Work.

Sources: Guada, Sample Survey; Spaniṣh Eommunity; Ottawa y985

After an analysis of the data and participant observation of the Spanish comanity we can suggest that although ethnic attach-. ment tends to decrease, with the length of residence, there are other variables which seem to have more influence on the level of ethnic ties: for example, level of education, endogamy, occupational status. It would need further research as we pointed out earlier to establish if the relationstip between "these factors and ethnic aftachment is significant." In the caseo of in-group friends it seems to have an intermediate influence on the level of ethnic aftachment; we have observed that although many individuals are highly acculturated and highly occupational3y adjustid, they still tend to have the majority of their friends within their ethnic group, contary to expectations. . 
Finally, despite the fact that self-identification was not an aspect under investigation in this study, it was observed that s.pontarieously, the subjects in the sample, either first or second generation, would identify thenselves as "Spanish", and not as "Canadians", Gindependent of their citizenship.

The majority of individuals in this study are Canadian citizens, but their reasons seem to be completely instrumental. On the contrary, they generally think about their children (native or foreign born) as being "Canadians", although in the home they try to maintain some of the aspects of the spanish culture, especially the language and other. uses, custons and values.

We can conclude from the analysis, of the three processes in the adaptation of spanish.imagrants in Canada, specifically ottawa, that is, Occupational Adjustment, Acculturation and Ethnic Attachment, that:

1) Men are more occugationally adjusted than women, mainly because they have, in general, a higher level of schogling and a higher occupational status con the Blishen scalel. Fsatisfaction with the job appears to be of less importance fhe majority seem to be generally satisfieda independeng of occupational status, number of years, ete.

2) Males appear to be better_acculturatgd than females. This can also be attributed to better education, the tendency to 
exogamy and single marital status (a high proportion). A very important factor influencing acculturation as proved in other studies is knowledge of the language. Married women with children tend to speak less English or French at home or at work because of their low status occupations which demand only a rudimentary knowladge of English or French"and their desire to make thejr children relatively fluent in Spanjoh. In-general the leyel of acculturation is not so much influenced by length of residence or age of arrival as by level of education, occupational status, exogany and previous migration.

3) The difference in ethinjac attachenent between sexes does not differ as much as the other measures. In general, the level of ethnic attachment tends to be medium; the use of spanish at home was predominant as were personal relations within the ethnic groupa, but there was low participation in ethnif anstitutions.

Contacts with homeland or frequency of travellang may not be - a fundamental aspect of ethnic identity, and may depend more or the socio-economics status or type of work there were indivgduals who had to travel very often because of businesst. The áverage nuaber of trips was every two to threê years; males showed a sight tendency to travel more frequently although they are more acculturated than women, but still they have an jdealized inage of the homeland and sometimes go to their country of origin, just as a place to "visit". 
4) When comparing the levels of acculturation and ethnic attachment we can observe that the adaptation of the individuals in this sample is "adhesive", that is, situational; depending on the circumstances the sparids are more "Spanish" or more "Canadian"? Cultural assimilation as Gordon argued occurs even when ethnic group ties remain (1964). 
Nợ

1. ine reasons ior not inteirvawing selected individuals were:

- retused to de intervieweo th

- topossiole to.locate

- ald not meet requirements : 1

uie to limitations ot tame and money these subjects were not suostituted to complete the torty (4ü) interviaws initialiy 1) thended.

6. Ine Embasy provioed just the names on thear regatration list, not their adoresses or celephone numoers, to guaranta conidoentiality. They promised the researcher that an interview would be arranged for then in the event that one or the indiviouals on the Embassy list were selected; but, this eqreement could not be carraed out ior various rasons that the soanish institution qave to the researeher llack ot time, change of the hmoasacor, among other,si.

3. Ht least three ot the temale sample mentioned having worked in a home for eloerly people itlliel Lodgei, on arrival in. ut t awa.

4. In Ejishen scale ja baedin an objective cale developed by relating income and occupation statsstics derived fion the Lanadian census. Estamates for the status of. occupations. were based on the average levels ot education and income ot persohs nolding each occupation, taking into account the known relationship between education, income ano joo status for the 85 related jobs (B)ishen and McRobertsi 19701 .

5. Ihe dificultr of spaniards to adapt themselves to the cold - temperatures was lso pointro out by 5acco (1958:20) in his study, carried out in Guebec.

o. Spaniards do not live indoors as much as do people who live in colder clinates. Usually "bares y.tapas" reters to the custom of drinking wine and eating an lamense variety ot tiobits, mainly in the tor ot seatood, betore meas, outside of the home (Martin, 1955:031."

i. There was a ajority who preterrod spanish wines at any time. Uniysseven respondents reterred to the consuaptron of other winesi two ot them who made the wine themselves.

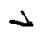


found during the years 1966, 1967 and 1968. The smallest number entering Canada during the 26-year period considered here is found in $1979^{\prime}$ when onjy 271 entered. There has been a steady decline of Spanish immigration to Canada that might be explained by restractions and changes in Canadian $1 \mathrm{mmigration}$ policies (e.g. -point system), the end of Franco's dictatorship in Spain, better economic and working conditions in Spaln, and perhaps the facilities made avalable for the migration of spaniards to European Economic Community countries.

*

There have been very few studies about $5 p a n i s h$ immigrants in Canada, and none in ottawa. The existing ones have mainly concentrated on the Spanish imnigrants Iiving in Montreal; Quebec and Vancouver. Very often they are mixed with other Spanishspeaking groups, or grouped with other south-European ethnie groups; therefore specific information about them is lacking. This is especially triue in the case of the census and other surveys.

Our sample included Spanish adult immigrants who arriyed at 14 years of age or over, who were fiving in ottawa. According to the 1981 Census there were 570 such individuals older than fifteen years of age whose country of birth was spain. We shave $x$ estimated that at the present time (1985) there are approxinately 500 households of Spanish origin in ottawa. Limited" financial resources and time constraints made it difficult to interview more than 31 individual's for our study. . 
CHAFTEK $V$

SUMMARY AND CONCLUSIONS

The present stuay is an analysis of the Spanisn comanity in uttawa, tocussing on the adaptation or 5panish jomigrants to life in Utrand.

since very liteié is known aoout spanish imagrants in Eanada in general, and in untariogand an ottawa in particular, this study ay oe viewed as an exploratory one and a starting point for tuture rejearch on this group in ianada.

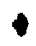

ithe data upon whach this sture

- The oata upon which this study is based were orantopitaraly troai I1) interviews with a sample of Spanish respondentsi 11) partacipant observation: 1111 secongary data existang on Spanish Imagration to tanada; and live content andyeis oi the tew oocugints that wewere abje to locate. Thas chapter wall outline the major tindings ano will conclude with a briot section ot recomenoations ör. Turther research.

In general trie research in triag study was guided by the writings op any sctiolarsi frga a theoretical point of yas, the : works of Gordon (1964), Porter 11965), Reitz (1974;1980) 19811 1982), Greton 1(964), Fuchmond (1967;1977), Nagata(1970), and Isajiw ilq75;1983i were very useful for our analyis. The writings of Anderson 11974;1970;1977); HIpalhao and Da Rosa (1980), Crimbos (\$980), Reynolds (1935), Huth and.kin (1979), 
among others, were used primarily to provide a comparative basis for our empirical evidence.

It must be borne an mind that the sample size is sall and because of the relatively small size ok-this communtty, there was considerable difficulty locating many of. The immagrants. Hence, while the findings may be interesting; they ar not always be generalizable to other settings an canada where spanish imigrants have taben up residence. Nevertheless, as will be noted below, in some instances Charactersstjcs of the sample correspend closely to characterlstics of the general spanish population in Canada.

Some of the central questions formulated before entering the field were answered through the gathering and analysis of the data. In some cases the information obtained via the iriterviews was inadquate and other sources. of. data were used.:

As noted - in Chapter One, structural pluralism is in our opinion the model of adaptation most appropriate, for the study of ethnic groups in canada: In this model, ethis groups mantain their primary relations within thejr own groupi but jarticipate in secondary relations with the wader society Gordori, 1964). It was assumed that the mode of adaptation of : Spanish jmmagrants would masmly be -"adhesive", "that is, on ane hand ther would be acculturated to a certain extent, but on the other hand they would retain some aspects of theiricticic 
culture: Depending an the situation they would be more "Spanish" - or mofe "Canadian" (Hurh ańd Kis, 1979; Herman, 1978; Richmond, $(974)$

situagion of the wider society (contextual approach) and the cultural and structural characteristics of the ethnic group, e.g. "primordial". attributes such as kanship, language, area of òr agin, among others (primordialist approach), were considered of crucial inportance in understanding the process of adaptation of the Spansh ethnic group and their maintenance of ethnic ties.

Ty better understand Spanish immigration, a-brief historical background of the socio-economic situation and prevalent values in spain, the hameland, were provided: The situation in Spain following the Spanish-Civil War was considered.important because of the political and econonic changes, which initiated the mass migmation of Spaniards to South America, Western Europe and.North. Anerita during the $1950^{\circ} \mathrm{s}$ and $1960^{\circ} \mathrm{s}$. The major push factars for :- emigratión from spain were economic, majoly thedow standard of Jiving and Tack of jobs, as well as the unstabfe poffelcal situation, a consequence of Franco'dictatorship.

The system of vajues dominant in post-war spanish society was briefly considered because there is a predisposition to attitudes, values and behaviours that the inaigrants bring to the receiving country. The suddenness of modernization in spain 


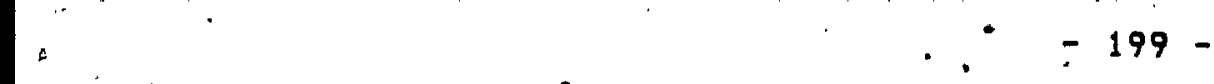

meant that the older value's of a pre-industrial society persisted in the era of rapid capitalist growth. A mix of secularization and traditionalism developed in spain, especially regarding family roles, religious values, and education, among others. In this study special attention was given to the general high value placed on individualism in spain which may help to explain some of the aspects considered in the adaptation of Spanish immigrants such as lack of participation in both ethnic and Canadian associations, lack of cooperation with each other, personalism and rivalries within the Spanish comminity, in Dttawa. This strong sense of individualis tog together with strong family ties was reflected in the process of adaptation of this ethnic group as we noted in earlier chapters:

Spaniards háve emigrated to Canada and the Unjted States in small numbers compared to other south Europeans, perhaps because - of the relative isolation and absence of formal relations between the Spanish and Canadian governments throughout various historical periods. The ondy agreements related to the immigration of Spaniards to Canada, as far as we were able to determine, were the "Operacion Bisonte" in 1957 and the "Operacion Alce" in 1960. These Spanish imigrants were destaned mainly for Quebec to perform farm and domestic service occupations.

Before $1956^{\circ}$ the number of Spanish immigrants resjont in Canada was insignificant and the targest proportions are to be 
found during the years 1966, 1967 and 1968 . The smallest number entering Canada during the 26-year period considered here is found in $1979^{\prime}$ when only 271 entered. There has been a steady decline of Spanish imigration to Canada that might be explained by restrictions and changes in Canadian iamigration policies (e.g. -point systen), the end of Franco's dictatorship in spain, better economic and working conditions in Spasn, and perhaps trie facilities made available for the migration of Spaniards to European Economie Community countries.

๘

There have been very few studies about spanish immigrants in Candda, and none in ottawa. The existing ones have mainly concentrated on the Spanish immigrants living in Montreal, Quebec and Vancouver. Very often they are mixed with other Spanishspeaking groups, or grouped with other south-European ethnie groupsf therefore specific information about them is lacking. This is especialiy triue in the case of the census and other. surveys.

Our sample included Spanish adult immigrants who arrived at 14 years of aqe or over, who were kiving in ottawa. According to the 1981 Census there were 570 such individuals older than fifteen years of age whose country of birth was Spain. Weinave. estiuated that at the present time (1985) there are approxigately $\ldots$ 500 households of Spanish origin. in Ottawa. Limited" financial resources and time constraints made it difficult to interview more than 31 individuals for our study. 
Our sample corisisted of 17 males and 14 females, mainly between the ages of 35 and 44 , who had been living in ottawa for an average time of 15 years. The ajority of them were married, although a higher proportion of males than one would expect were still. single. Most of the indjuiduals in the sample were married to Spaniards and a high proportion were canadian citizens. The average age at time of immigration was 26 years.

Very few of the respondents came directly to Ottawa; often their first destination was Montreal, Toronto or other canadian fities. During the 1950's and $1960^{\circ} \mathrm{s}$ Spanish immigrants tended to be concentrated in Quebec, but by the 1970 .5 and 1980 's there was a tendency to settle in Ontario. In the 1981 census, $70 \%$ of the Spaniards live in Toronto.

Most of the inteviewees came to Canada directly from rural areas in Spain; specifically the northern regions and Andalusia. They tended to come with their nuclear fanjlies; unlike most of the other south European immigrants (Chimbos, 1980; Alpalhad and De Rosa, 1980). This is also the pattern found in the total

Spanish immigrant population in Canada ilamigration Statistica, $1957-1983)$.

There is a large representation of non-sponsored inaigrants. This can be explained by the fact that there is arge proportion of: single wales in this sample who came to canada - injogendently. Another reason is to be found in the males 
higher level of education compared to the females in the sampie: The motives behind the dgrision to migrate were often expressed in economic terms: hightr.wages, better housing, more material comfort and other general advantages..

It was learned. in this research that Spanish immigrants do not tend to be residentially concentrated, although there are one or two very small pockets near Vanier and south-east areas of Ottawa.

According to jmoigration statistics, interided occupation of Spanish immigrants on theif arrival in Canada has been mainly located in the manufacturing, construction and professional and - technical sectors, especially during the period 1957-1961, whereas for the subsequent years they have been located in fiachining and related service and professional, especially science and engineering sectors. These main trends are reflected in our sample, where most of the crespondents were concentrated in the professional and service occupations. Not many of the are working in the machining or construction sectors people with those skills would be more likely found in industrial cities such" as Toronto or Montreal.

$\checkmark$ Friends and relatives were found to be very important in this study, not only as job hunting channels, especialiy for the first job, but also as the spanish iamigrantio main helpion their arrival in Canada: 
We, were not able to establish the existence of an economic specialty for Spaniards, due perhaps to sample size." They seen to share south European occupational niche's such as 'janitors, domestic service, waiters, etc. It is unlikely that there are many ethnic enclaves because there are not many entrepreneurs or self-employed Spanish imajgrants in Dttawa. 'Evidence of this 15 the large proportion of the sample who work for a Canadian or - non-south European employer.

The women are mostly concentrated in jobs considered menial and with low prestige, mainly in the sérvice sector: maids, cooks, "live-out" domestics, etc. Analysing the occupational" concentration of males it was observed that they are distribyted either in low status or high status occupations, In general, unliké Richmond's $(1967)$ immigrants study, the:respondents with very few exceptions (an engineer, a machinist, a pharmacist), have not experienced occupational dislocation. In general, comparing their present situation with their former situation ${ }^{-}$in spain, they have experienced some upward mobility, even though

they have accepted and still do low statusi jobs in Canada.

In the case of females it was shown that the first occupation held in Canada has been a deterninant of their low occupational adjustaent and maintenance of their mentrance status". With very few exceptions; these fenales have tended to ienter low status occupations and have not been able to move from 
then, basically because of lack of akills, few opportunities for training, and lack of knowledge of one of the official languages in Canada. In general, Spanish immigrants in Canada tend to be. satisfied with their present jobs and alsost haif of them would not like to,change them. This is especially true of the women.

As notied earlier, lack of fluency in one of the official languages of Canada is one of the major barriers to integration into the wider speiety and it is very closely related to other aspects of the adaptation of inmigrants, especially occupational adjustment. The majorjty of respondents in our sample speak English. at work although sometimes, this is very limited, only a few techrical words or common expressions. As.is the case with many othir ethinic groups in Canada, they are primarily oriented to Anglophone society because of econopit opportunity. As Reitz argued, this is reflected. in their patterns of settlement, Ontarjo and Quebec, especially Montreal where there is an influential Anglophone minority" (1980a:346).

Spanish immigrants, like other ethnic groups seen to be satisfied with their lives in Canada, speeifically in ottawa. This has been considered an important factor in the acculturation of ingigrants. They mentioned the great economic opportunities - in general as weil as the existence in Canada of better organjzation, wore order, freedon, equality, etc. compared to spain and other countries. 
The majority. of respondents in our sample intend to stay in Canada, although there are "nostalgic" feelings towards their. country of origin. In terms of adaptation to the host society, the importance of education has to be pointed out. It was found that the better educated individuals were more adapted to the new 2

context, especially if they knew the janguage before coming to Canada. As Reitzihas argued, education affects not only the occupational or econonic adaptation of imigrants but also "helps to. speed up the rate of adaptation to Canadian culture and society" (1980:191): Imaigrants witti a low level of education have stronger ethnic ties and tend to learn the new language, values, customs, etc, more slowly, especialiy if they cone from rural areas, have not had previous migration experience, and are married within their own. ethnic group.

Before 1964, the Spanish comadnity in Ottawa consisted only. of a network of personal, relatians. Friendship groups and. cliques were formed, but there were no. formal organizations. A.t. present the spanish community has developed a more formal structure and basically has three organizationsa religiouse Pecreational and educational- There-are very few other ethicic. servicas. Compared to other south European groups such as Italians in Ottawa, their organization, is weak.and members of this ethnic group have to use host institutions for the satisfaction of ast of their needs, such as work, food and clothing, education, social assistance anong others. The Spanish community in Dttawa is low in teras of "ingtitutional coapleteness", using a concept developed by Breton (1964). 
As we saw in earlier chapters, the Spanish comunity survives in ottawa without the support structures faund in communities with" large foreign ethnic populations. Minority ethnic communities in canada tend to be camposed of people with low status occupations., It is not veriy frequent that people with high status jobs keep their ethnic ties, as Reitz has argued (1980a). Although evidence of this was found in our study, middle class respondents were still socially distint from the host society, having most of their personal relations stil within the Spanjsh ethnic group. The people interviewed for this study. can be described as primarily working ó low middle class in origin composed of unskilled, semi-skillet and skilled workers), and a minority of upper middle class, mainly. represented by professionals, entrepreneurs, etc. The usua! criteria to define social slass are social prestige and economic and political power: Commonindicators of economic status are occupation and income. Due to difficulties in obtaining the annual Fotal income, occupational status has been the criterion used here to determine the individual's. social class.

There was a tendency in the pefossionat wpore fiddectas group to be dissociated from their working class compatriots and as a consequence they do not generally participate. in the Spanish associations: At the sane time we found in this study that most of the acculturated individuals - who were also well educated and peneraliy occupationally adjusted - jdentify thenselves as. nembers of the Spanish ethnic group even though they are not very. interestad in returning to spain and may consider thei 
- as a place to visjt occasionally. They travel very frequently to their country of origin, maintain some aspects of the spanish culture it home (values, language; food, etc.), although they are Msually isolated from working class Spaniards in the city.

Even those with fifteen years or more of living in canada and the most acculturated individuals in the sample in terms of adoption of some cultural patterns of the host socjety, are still self-conscious of their ethric group at least on some occasions and in some relations.

Lowly educated spaniş immigrants showed an intérmeduate. jevel of acculturation and economic adaptation, but a higher. level of ethnic attachment compared to the well educated. These individuais tend to participate more in ethnic associations and have friends within. their ethnic group to a greater extent. Breton' (1964) argued that participation in at least one of the ethnic institutions increases the in-group friends. It doess not appear in this study that friendship has been inherited from the same area of origin in spain, except for a'few cases. Spanish relate to other spaniards whose area of origin is not necessarily the same as their own. This-may, be due to the relatively gmall size of the community.

This research indicates that social integration rarely occurs in first generation spanish inaigrants larid very probably second). Although Canadians Were defined by some Spanish 
inaigrants in ottawa as being cold, selfish and not very friendly"; they are willing, apparently, to establish primary relations with them; however some of the Spanish inmigrants perceive difficulties in peing accepted by the natives and they are also aware of the existence of communcation barriers because of their general low skill in speaking either one of the two official languages. At this point, in this stage of adaptation, Canadians are aainly acqujintances, not intimate friends.

On the other hand, the low degree of social integration can not be explained by the existence of a very strong identificiation - of Spaniards with their ethnic culture, because jn our opinion: the preservation of some ethnic values and customs is constrained to the home exclusively. Thejr ethnic attachment is "adhesive" or "situational" as noted above, mainly maintained at home Ifanjly relation patterns, language use, diet and food habjts, anong others); they also relate to small different groups of Spanish or Latin American friends, in an individualistic manner. - The only ethric collective activities that they appear to join occasionally art of a recreational type li.e. weekend ethnic Felebrationsl, and sometimes religious activitios. Eernandez in his study of Spaniards in Montreal (1972) has observed that people. may have parallel loyarities; e.q. Canadian and. Spanishoeach of which becones significant or are utilized in Gifferent contexts" (1972:23). Also Nigata (1970), when studying the adaptation of Greek imagrants in Toronto, has aroued thiat ethnic identity or attachment is usually restricted to a private domain (home, church, ete.) while Canadian values tend to be oore 
consistent in the public domain, especially in employment attuationg". Spaniards in Ottawa-tend to participate directly in Canadian economic institutions; they are involved with the wider society through the mediun of employment, with some exceptions of individuals who work in the few Spanish or south, European enclaves (Italian, Portuguese) existing in Óttawa.

Although there have been partial changes in habits, and values : in the enigration process, Spaniards seem to preserve certain aspects of the spanish culture such as extended fanily, ethnic language at home, parental authority at home, respect for the aged, among others. They have adapted to new ways, without renouncing their traditioal patterns. In general, we could say that they are not' typically Spanish nor typically Canadian: they 。 are. in a transitional stage.

\section{Eurther_Résear $\underline{\text { th }}$}

On the. basis of the present evidence it would be of particular interest to study the process of adaptation and maintenanie of ethnic culture among esecond generation spanish-

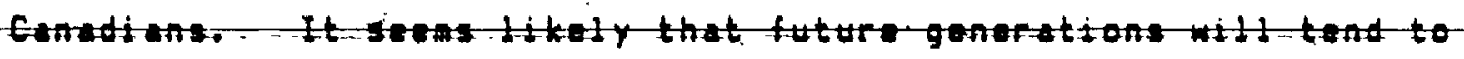
a lesser degree (compared to adult inaigrants) to preserve their ethnic ties, and on the other hand, they will slightly increase their integration - economic, cultural and maybe social - into 'Canadian society. It is difficult fo forecast how fast their social integration will be, especially because this depinds on the willingness or unwildingness of the anjority, groups to allow large scale penetration of its social institutions by abers of 
ethnic ainorities. It would need further researich to determine if the ethnic identity of spanish imagrants in ottawa is gaing to be strengthened or if on the contrary individuals will discociate and therefore the community will disappear. Breton (1964) has. indicated that:

"If the rate af migration is low, the ethnic public. will progressively decrease because even. a high dagree of institutional completeness will not prevent some integration into the native community... Ethnic communities are formed, grow and disappeari they grow through a jife cyele..." (1964:205)

Hansen's, hypothesis of the "third generation return" cortradicts the thesis about the disappearance of ethnicity when the second or third generation becones fully integrated. The prevalent pattern among the first generation seems to be preserving the culture of the ancestral group; generably, for second generation there is a conflict betweer the ethnic 'values at home and the values of the host society: But then, the third generation mainly acculturated and jintegrated, "may rediscover. his/her ethnic origin, not in the sense of returning to the old. culture but in finding aspects of it meaningful to his/her present outtorn af -1ife" Sin Breton 1975185$)$.

Whether this pattern is going to be developed by the spanish second or third generation spanish in ottawa has yet to be seen. But, most of the second.generation Spaniards in general, have not yet reached aturity, and although there are very feì spanish ianigrants coming to Canada includino ottawa, due to present Canadian ianigration restrictions, and better conditions in spain 
(democracy, economic development, Conaon Market, ete.); there is no reason in our opinion toothink that the Spanish community will disappear in ottawa in the réar future, despite its low institutional completeness, in Breton's terms., Socialization at home will perhaps continue transmitting spanisp values, uses, traditions; and especially the spanish language. They will not want their culture to be lost in Canada; thas was clearly observed. in second generation subjects (who migrated as teenagers) whose positive and strong ethnic attachment was shown during the interviews. Again, "it has to be seen how the ethnie culture will be majntajned without the influx of new imnigrants wha, in Reitz's opinion, create conditions "to reactivate the ethnic ties of older immigrantg and of those of second and thifd generation" (1980a:234).

Perhaps second generation ethnic ties may weaken in the future, especially if they marry outside their ethnic group, and if they achieve a higher education level than their parents.

Further research shöuld also confirm if second and third generations of Spanish-canadians will achieve higher level occupations. These new generations will not have language problems as most of their parents did, especially inmigrant women who were segregated to occupational. niches such as maids, cogks, cleaning ladies; etc. because those were the only jobs they could, perfor without knowledge of the official languages, and with very low education level and few skills. 
Another aspect that should be investigated is the return to the homeland of Gpanjsh jmmigrants, after thay retire in Canada lor maybe beforel. This, in our opinion, would be important not only to see how thei faptation process occursi but also because this returning or not to spain would have a very important influence in thejr chijdren's descendentis in terins of maintenance of the Spanish culture. As noted earlier, the Spanish style of life is centred on the rome for the most part, and extending from home to imgediate relatives and close friends. On the other hand, the elderly, $"$ as stated before, are a central pillar in the Spanish extended families, as weli as in other souther European,groups, such as Portuguese. (Anderson and Higgs; 1976) and Greeks (Nagata, 1970; Chjmbos, 1980). They are usually child-carers, and therefore if they remain in canada cfirst generatjon adult imigrants in our study), ethnic values and culture in general would more likely be transmitted at home as part of the socialization process. The importance of the family unit is pivotal in the maintenanceiof ethnic uses and values (Borrie et" al, 1956;"Ishwaran, 1980).

It is also considered important that more research on entrepteneurial success of Spanish imaigrants and also existence of ethnic enclaves be carried out. In a larger stratified sample, it would be possible to establishthe proportion of entrepreneurial squxigh jmmigrants, and how many of their enterprises can be considered ethnic enclaves which provide jobs. for Spaniards or other minority ethnic groups in ottawa. The main 
focus should be to.find the existente of ethnic enclaves where education of the imingrant does not seen to have significant. - role in terms of economic achievement, as Anderson (1976), Herman (1978) and Reitz (1980)-have shown.

of particular interest will be the study of inter-ethnic relations between the spanish immigrant group and other minority groups in Canada, especially Italians, Portuguese, Greeks, and Latin Americans, among others.

Throughout this study, the existence of an "elite" amorig the spanish immigrants in ottawa was cleariy revealed; they are highly educated, to a certain extent acculturated and generally dissociated from their working class conpatriots. These intellectuals constitute a "community" of their own that requires spetial attention and reșearch using a comparative analysis for example, between this intellectuaberite in Ottawa and the one. existing in Montreal or Toronto. "Information given on the perception that menters of the Spanish community have about the. existence of this elite would also be of interest.

\section{ConE 1 usions}

The present study; as pointed out earlier, should be - replicated in a different Spanish imagrant population, to determine if our findings are unique to this selected population or whether they apply to Spaniards in Canada as a wole: 
The findings presented in Chapter four might be speculative, but they provide some insights into the complex process of the integration of immigrants to the receiving countries.

The data obtained. from the thirty-one interviews, limited as they are, give a preliminary assessment of the degree of occupational adjustment, acculturation and ethnic:attachment of Spanish immigrants in ottawa. In general, it appears triat Spaniards residing in ottawa have an intermediate level of occupational achievement, acculturation and maintenance of ethnic ties: Similar to most of the other south European immigrants in Canada, they are not yet integrated into Canadian society at the primary group level:

We could say that the majopity of Spanish.immigrants in Dttawa arè jin a transitional stage of economic and cultural incopporation: "They have not reached the integration "stage because of their uneven distribution in the Canadian occupational structure, and high concentration in low status occupations.

It is hoped that the naterial presented in this thesis will contribute to some extent to an understanding of the process" of adaptation of immigrants in a pluralistic society, specifically. the Spanish ethnic group in ottawa. A major aim of this work is to start withi the study of Spaniards in Dttawa as a base for. further research on the Spanishinigration, in Canada. Moraextensive data are needed for comparisons of Spanish imaigrants in other Canadian cities, and with other ethnic groups. 
Generalizations frop this study are limited not only because it refers to a small gorup of Spanish immigrants in ottawa, but because imaigrant groups are not homogenous, they have specific characteristics that may vary from one setting tóanother.

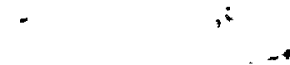

8
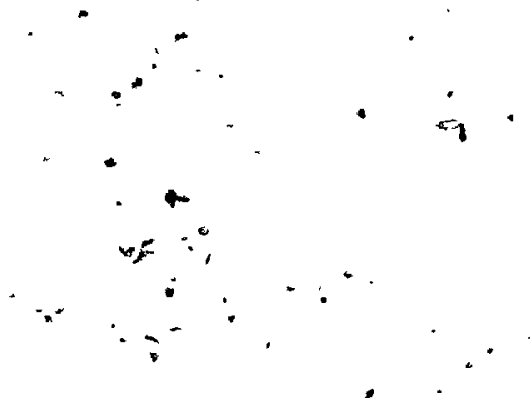
1. Some positive results have been achieved in Spain during recent years, especially with respect to an improvenent in industrial activity, in the bajance on current account and the inflation rate. Nevertheless, there are still negative aspects such as the inesease in unemployment and the current deficit loficina de Informacion Diplonatica, Regortage, No? 367). According to Krane, one of the first steps in the democratization of Spain in order to resolve the econonie and social problems creating enough jobs, has been joining the Comon Market as a full member, "which will. give the Spanish labour force the freedom to move throughout the Comon Market and thereby remove many of the existing. problems" 11974:1631. However, it has to be seen. how Spain's full participation in the Common Market helps to solve the unemployment and inflation problems. According to an opinion poll carried out in nine industrialized European countries, spain occupies the first place among countries regarding unemployment and the general economic situation as their "main concern" (Spain__84, Vol. 13, No. 126).

2. Education itself is a component of socio-economic status and also can be considered an indicator of predisposition to modernity and potential integration into a modern industrial socjety (Porter, 1979 ).

3. There has been. an increasing exogany an minority ethric groups which is important because of the role that the mother plays in the socialization of the children and learning of the language. (Porter, 1.979:279).

4. Spanish immigrants in general do reinforce educational aspirations and achievement of their children at home. This support and motivation for achievement was found in our sample; in general second generation Spanish-Canadians tend to complete high school and some of them continue on to university. 
Acevedo, J .

1971

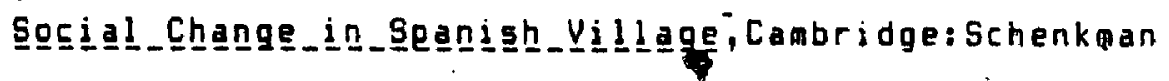

Alpalhao, J.A. and Da Rosa, V.

1980

A Minority_inga_Enanging_Sogiety, Ottawa: University of ottawa Press.

Ariderson, $B$.

1974

Networks_of Contact: The__Portuquese _ 1n _ Ioronto, Waterloo: Wilfidd University

1977

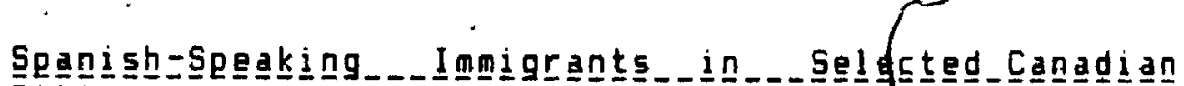

Cities, Burnaby, British Columbia: simof Fraser University

1979

"Spanish-Portuguese Speaking Immigrants in Canada", in. Ell i ot, Iwo_Nations__Many_Cultures:_Ethnic__Grougs_in

Canada, Scarborough: Prentice-Hali.

Anderson, G. and Higgs, D.A.

1976

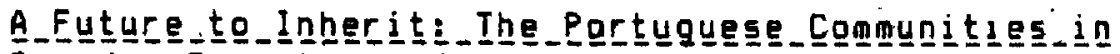

Canada, Toronto: McCleljand and Stewart.

Anderson, G. and $[$ larke, $J$.

1973

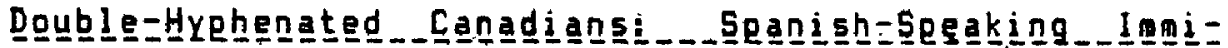
grants _of_Gernan_Background in the K Kitchener-Water loo Area -of ontario, mimeography, waterioo: Waterioo Lutheran university.

Arnopoulos, 5 .

$t_{i \infty}^{+\infty}$

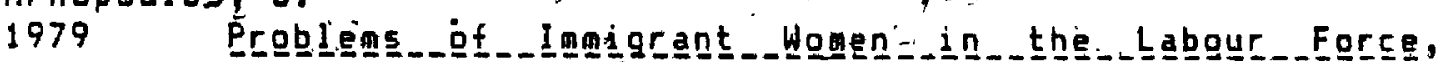
Canadian Advisory Councin on the status of the Women, Dttawa: Supply and Serviceg. .

Berry, J. et_a 1

5977 Mult

Berry, J. and Tishler, $H$.

1978 Rage and_Ethni

Blisheri, B. and Carrol, 0 .

1978 . "Sex in Socio-Economic Index for Occupations in Canada." , Canadian_Reyiew_of_Sociglogy_and_Anthrogology 15, pp. 352-37.1

Blau, P. and Duncan, 0 .

1967 The Anerican Decuedtional_structure, New York: John Viley and sons.

Blishen, B. and MeRoberts, $H$.

1976 "A Revised Socioecononic Index of Occupations" Canadian Reyien_of_Sogiglggy_and_Anthrogology, 13, l: po. 74-79. 
E11 shen, 6 .

1976 . "Social Class land Opportunity in Canada", Canadaan

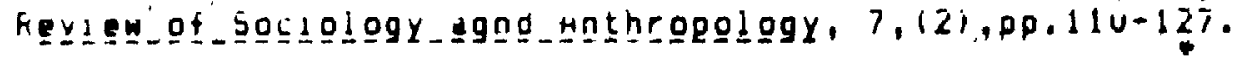

borneck, J.e

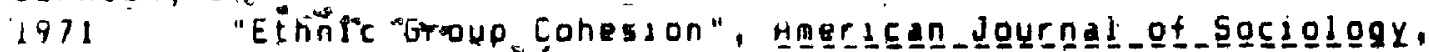
io, PP. $33-45$.

ciorrie. W. et. 1

1750 Thécultural Integration of Imagrants, UNESCO Conterence, La Havanda

bottomiey, u.

by

boyo, H.

lyis "The Status of Immigrant women in Canada", Canadian Fev1ew_of_5oc1 ology_and_unterogology, 12141,pp, 4ús-415

oradgord, 5 .

1902 Spa1n 1n the Wor 1 d, Princetons D. Van Nostrand Company inc.

breton, $F$.

1904 . "Institutional completeness of Ethnic Cominaties and

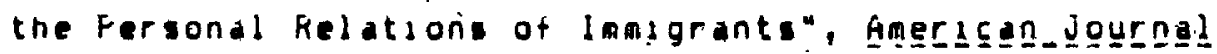
of_5gc glogy, $7 \dot{u}, 2 i$ pp. $1 \bar{y} 3-2 \dot{u} 5$

Greton, K. and koseboriough, $M$.

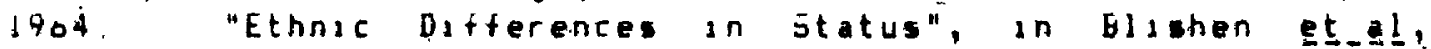

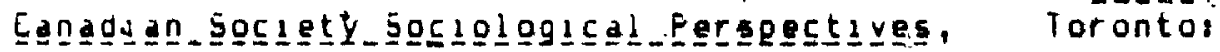
McMilian.

Eretion, F. and Fanard, H.

1904. "Group Formation anong Inmerantsi Crateria and. Pro:

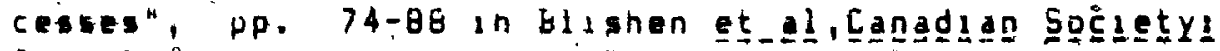
Soc 10 loglcal Ferseget 1 ves. Torontoimcmilian.

Breton, k. et a

1975 "Analysas of Literature Research Issues on Canadian Cultures and Ethnic Groups", Cangdan Feysew_ot Soclology and Anthrogologr, 1Z, pp: $8 \bar{l}-74$.

breton, K., Isasiw, W. and keitz, J.

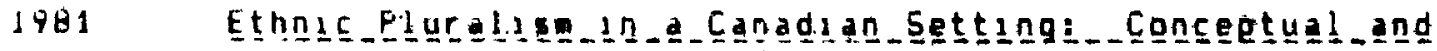
Iechn1cal overyiew _of d Research Project, foronto: ientre ior Urban Commuitty studies, Researeh Paper $21 ;.$ DP. $147-408$.

Bretteli, C. and Da Rosa, $V$.

1974 "Inmaration and the Fortuguese Fanily: A comparison between. Two Recelving societies" "pp. - et_al (ed), Eórtugal in_Develoegent, ottawas University or Qttawa Fress. 
Lanada, Cistzen Brancen

$1 \bar{y}$ i9.

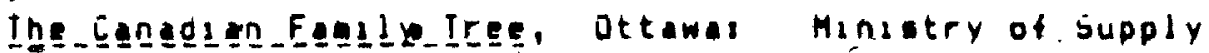
ano bervices

Canada, Lepartment oi Catszensensp and Imagration

1950-1965 Quarterly Imagration Euldetin, Ottamal Quean. Frinter

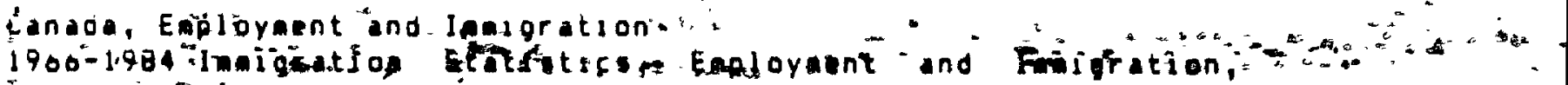
- Ottawar Queen srinter

Canada, foyaí commission

Ih70 Royal Comassion on the Status of the Women, Minister of Supply and Services, Ottawa.

Lanada, Foyal Commssion on Eijuguadisn and Biculturaliso

1973 Vol. 4, Ottawa: Intormation Canada

Lanada, 5tatistics Canada

$1981^{\circ}$. Census of Canada, Ottawal Gueen. Franter

Liartand, R. and Fusl., J.

1979 Sea1n_Dıctaterghye_to_Demosracy, London: George Allan. and Unwin

Larta de España

$15 \overline{5}$ Revista de Enigración, Horil, Madrid, No. 304.

Castle, 5 . and kosacksib.

$15 i 3$ "The Function of trick Labour Migration in-Western European Capitalism", New_teft_fevien, i3, pp. b-21.

Chising, F.

1778 Uccupational Mobility and Achieveents of P'ost War Chinese imaigrants in Montreal, M.A. Iness, Migall Unisversty

Chinoos, f.

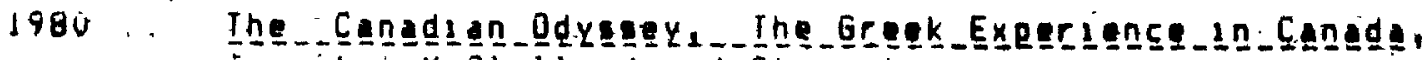
For onto: MeCjelland and Stewart

Warroch, 6 . 1981

"Urban Ethnsclty in Canadas Personal Assiajlation and Political Communtics", Canadian_Reysew.of Soczology and Hnthrog.ologY, 16, pp. . $35-90$.

Eavis, î.

1975

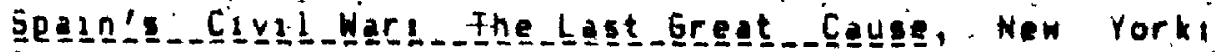
iutton and io.

Lenssi, $n$. 1981

"Fenness Ethnte et Occupation au Quebec et Ontario;

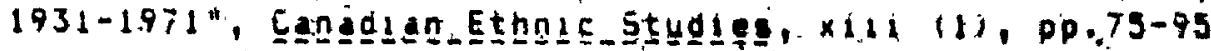




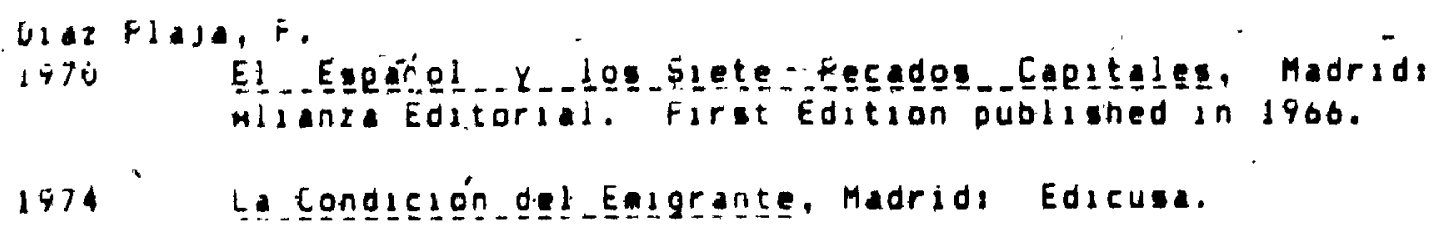

Fernánoez; $k$.

1yiz Ethnjesty as a Symool Systeni A Theoretical Discusasion Exemplified by Case studiex of spaniards in Montreal. M.H. Thesis; Mcgili Unaversity.

Fernández, H.

ty84 "Una Comunidad Espaũola en Santa fo ý su Sociedad de Socorras Mutuos" in Stugr Eglgrazıone, hnno xxl, no. T. . . . $00.100-\angle U T$.

Fisher, 5 .

1479 Changing Fatterns of Sociaj Drgansation. among the Ehinese in ittawa: A atudy of Internat and External Determinants; Fh. D. Ihesis, Carleton. University.

Fisner, W. and Jones, $b$,

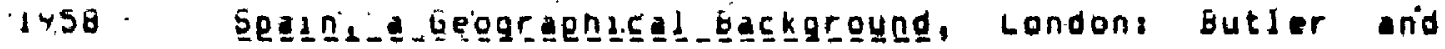
tanner, Lib.

Frstonan, j. et $\underline{a} \underline{\underline{1}}$

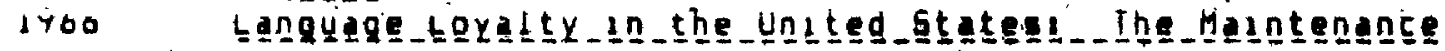

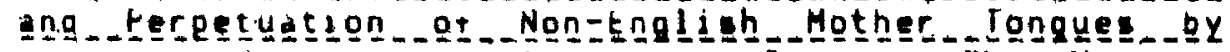

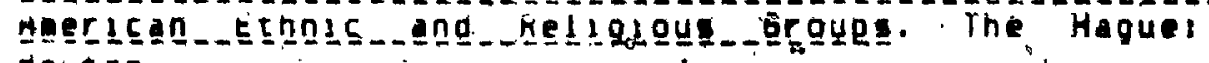
nouton. $\therefore \because 4 ;$

varmenda, j:

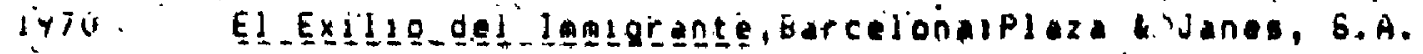




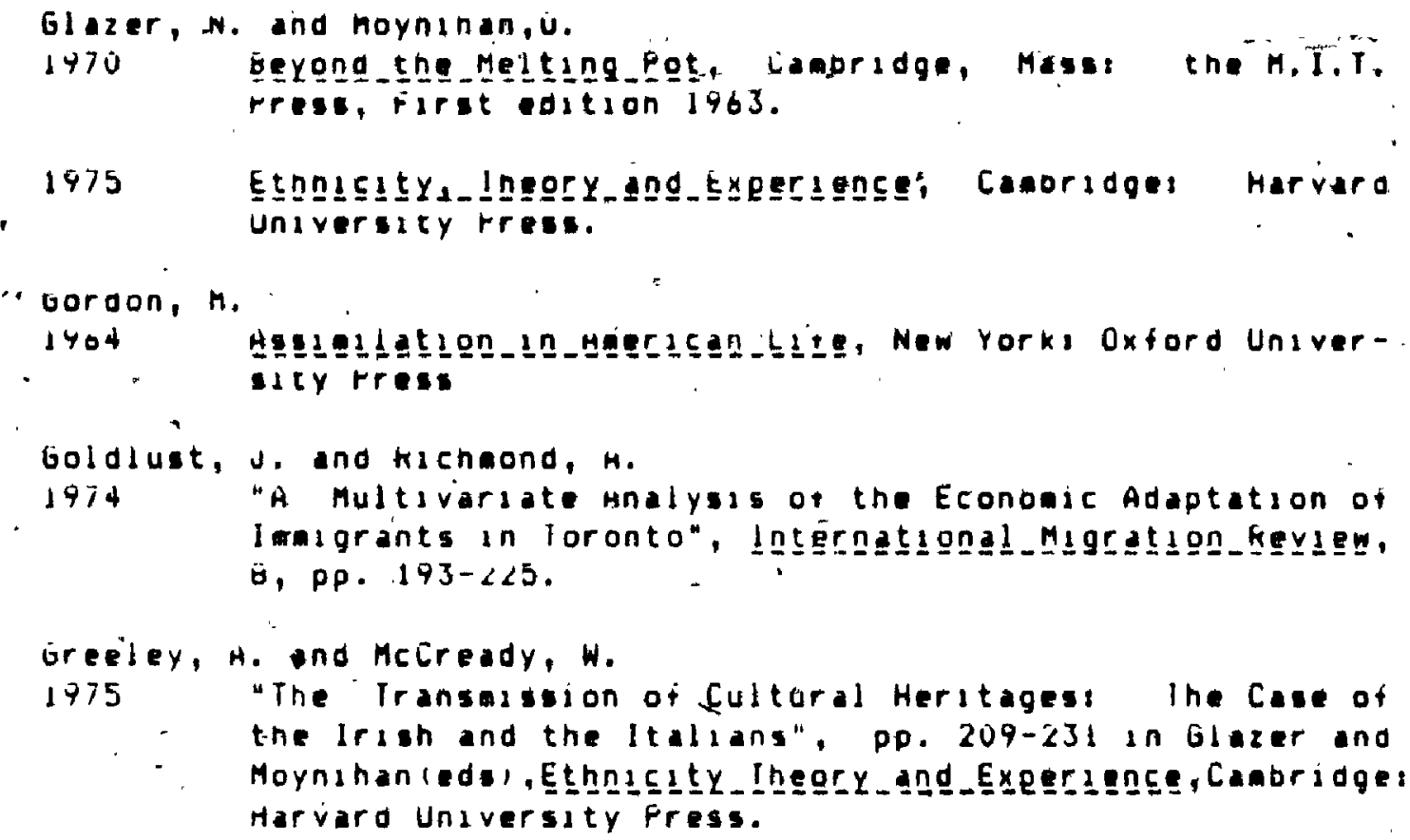

Halli, 4 .

1473

"The Canadian Division of Labour Revisited" in Curtis,

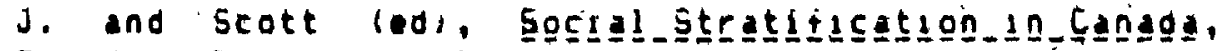
Eanadal Frentice Hald

Herman, H.V.

1978 Men_1n Whitéferons, Toronto: Peter Nartin Associates.

HermeneglJo, H.

1565 "La Pluralité des Higrations Espagnoles au Quebec*, Unpublished Faper presented to the Canadian Ethnie Hssociation, Esghth Esennal Conference, Montreal. 


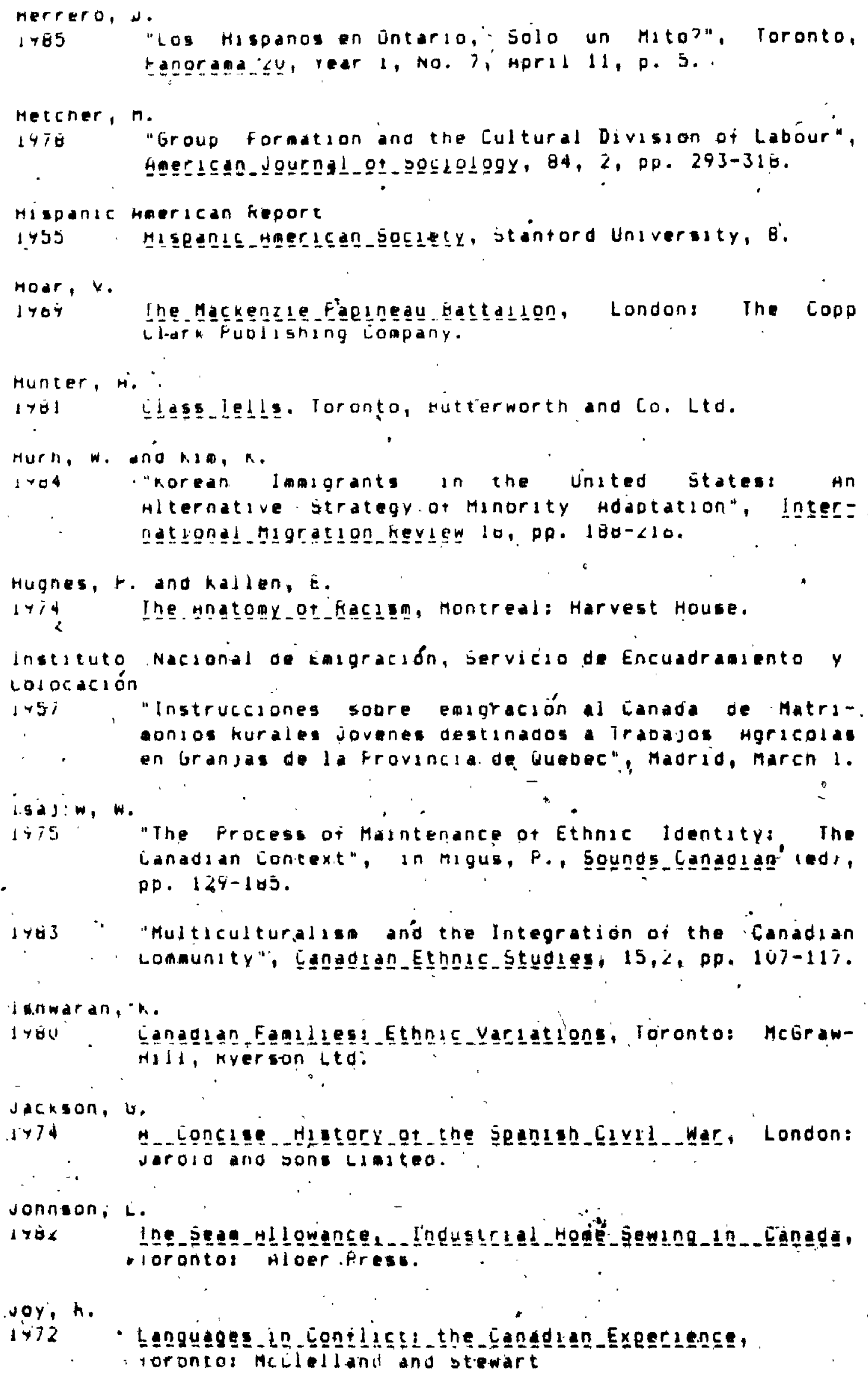




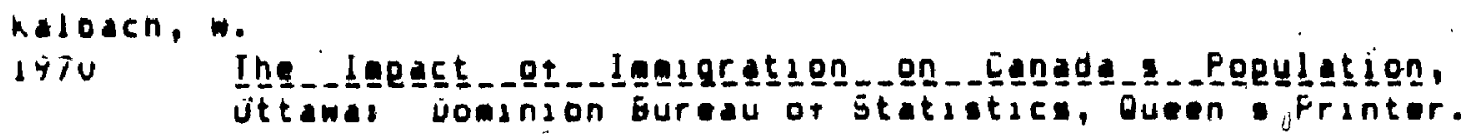

Martin, K.

1755 'The_Land_and_People_oi_Spaln, Londons Morranson and. bibb Ltd.

Maxweili. i. $1 \div \div 7$

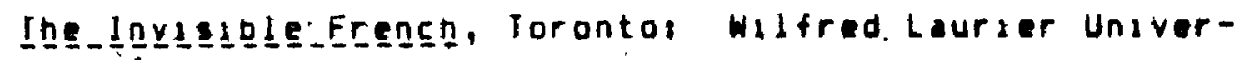
sity Press.

ncilurry, $k$.

1979 ine Decupational hojustent of Vietnamese kefugees in tomonton, M.H. Inesis, University of Hiberta.

Melaggart: $E_{1}$.

1979 Hingritıess_Eender-and_Work, Lexington, Mase. D.C. ano Lompany

M1 11 et, 1. 1479

"Religious Identity: The Non-Ufficial Languages end

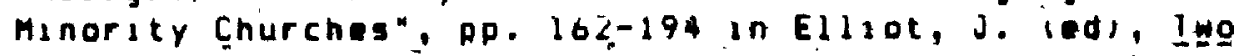
Netgons. Many_Eultures, Scarborough: Frentice Hall.

Moskós, i.

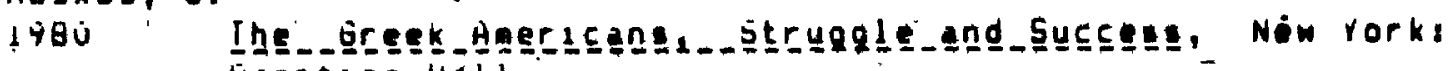
Frentice Mali.

Muñaz, j. 1970

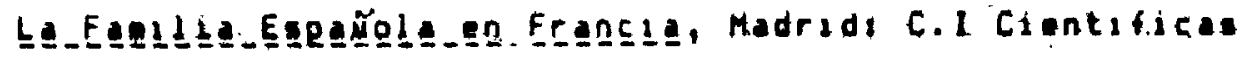




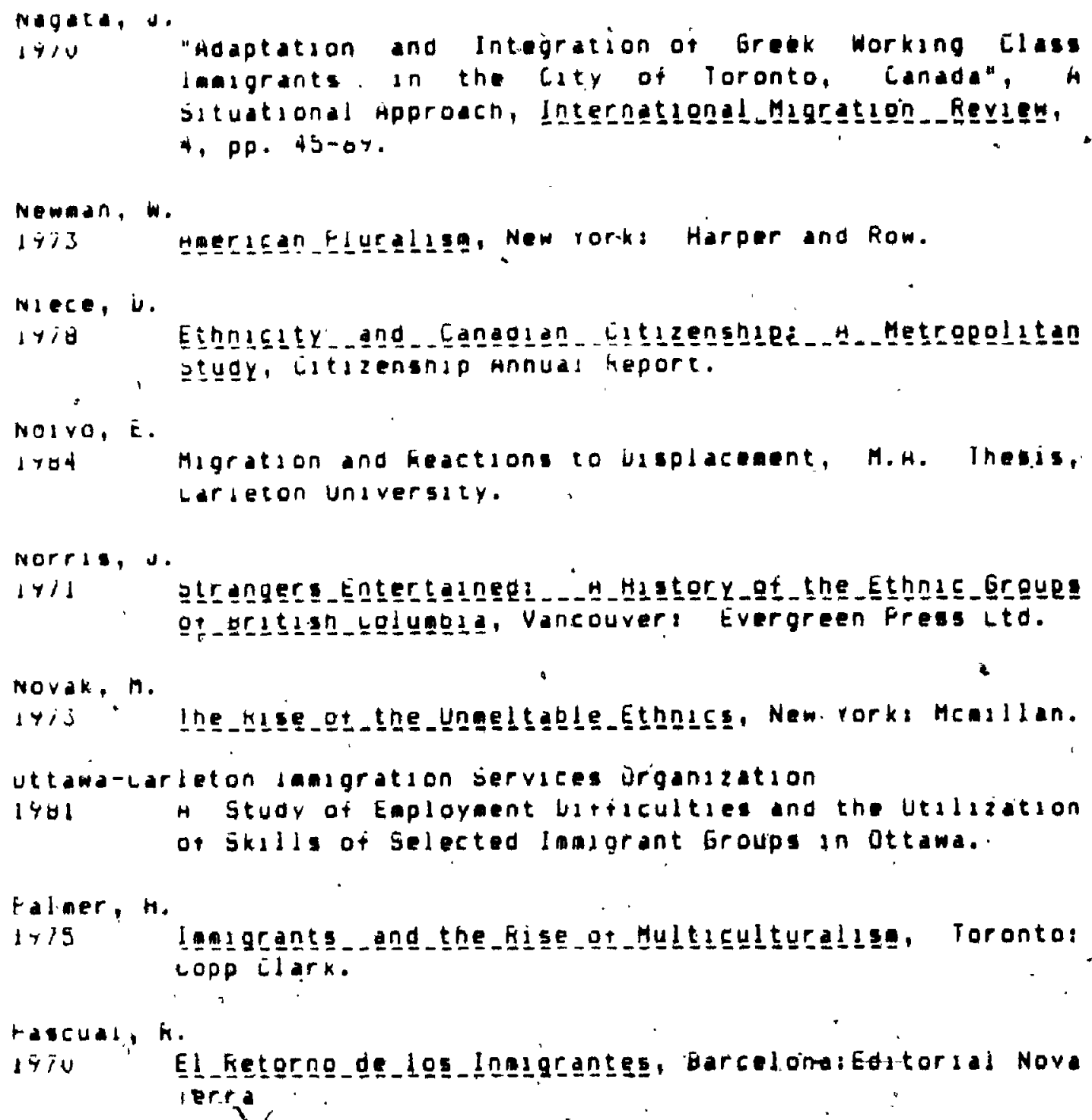




\section{Forter, $J$.}

1705 Ine vertsegl Mosdíg, iorontos Unsversity of Toronto rress

litic Ihe Measure ot Eanadian joglety, Torontosiage Publishing

rralile maniower keview

l.yog Manpower Intormation ano Hnalvsis oranch, 0ttawal Lepartment o* Manpower ana lmagratıon, $1(\bar{\psi})$, Novemoervecenoer.

Fu:zo, is. 1 ró

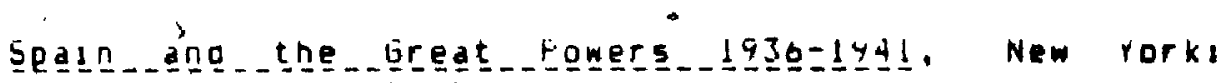
Lodunula university fress.

helrz, J. $1+14$

"Language and Ethnic Community Survival, Eanadian heyı PP. $164-12<$.

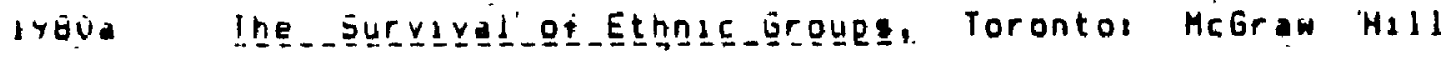
nyerson

198üb "Imagrants, their oDescendents and the Cohesion of Canada", $P D$. 331-4lu in Breton, R.. Feltz, J. and Valentane leds), Culttural__Boundarses_and_the_Cohegion_of idndda, Montreadilntitute tor kesearch on Fublic Poljcy.

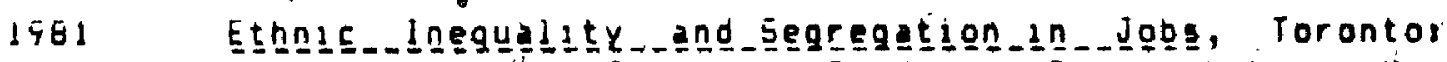
Centre or Uriban Comanity Studies, Fesearch raper No. $12 j$.

$1 \overline{8} 82$ Ethnıc_öroug_tontrol_oi_jobs, Toronto: Centre for Urban comaunicy Studiesi kesearch Faper No. 133.

keynolos; $H$.

1935

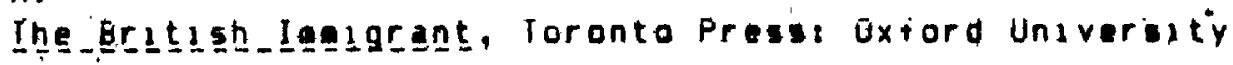

Kicnaona; $H$.

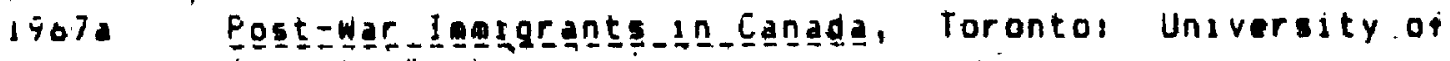
ioronto fress.

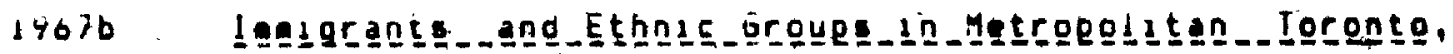
loronto, rork University.

$1970^{\circ}$ "Iamigration and fluralism in Canada", Intergatsonsl Mıgration kev1ei, 4i pp. $5-\angle 4$.

1974 Hegecte ot Hegorptzon and Hdaptatzon_ot_lngigrants, úttawa: Department of Manpower and imigration

1974 "lamigration and kacial Frejudice in britain and

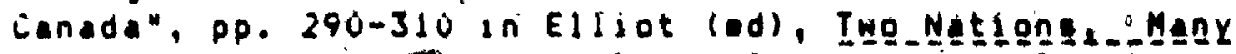

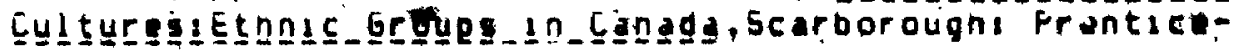

in Hall. 
Kicnaona, H. ana verma, $k$.

1477. "The Economac Hdaptation ot lmalgrants: 4 New Thecrstical Ferspective," Integnat 1 ona pp. $3-3 i$.

Kal st, t. 1478 Guestworkers_tñ germany. New rork: Praeger Fublishers

$\operatorname{hog} 9, \quad c$ 1474 Ine_Hs rress.

Kuto, J. $1>14$

La E ariel.

sacco, J.

1450

Histoire oe f'lmmigration des Espagnols au. Lanada et plus particulierement aans le wuebec et ce qui caracterise ce prooleme, M.H. usssertation, "Laval universicy

sengstock, M.

1478 "Developing an Index of Ethnic Community Fartici-

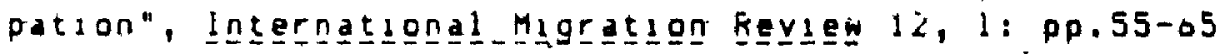

Span rearoook

Iy甘z Instituto Nacional de Estadística, Madrid: I.N.E. Artes 0 urálicas.

sturino, $r$.

1478. "Fandy and kin Cohesion among Southern ltalian Inmigrants", "an Carola et_a!, Ine Ital 1 an Immigrant women

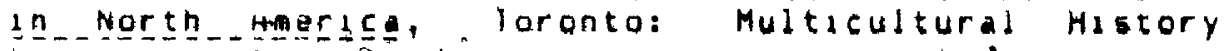
bociety ot untario.

iuritin, $\mathrm{d}=$

1970 "Networks and Mobility: The Case of West Indan

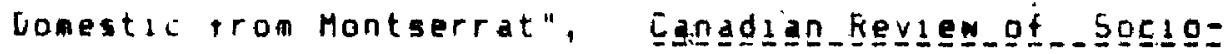
logy_and_hnthrogolggy, 13, po. उús-3ív.

1977 . "We don t look. for prejuace": Migrant Mobllity Culture anong Lower status west Indian Women from Montserrat", pp. 311-324 in Eliot,J.(ed), Iwo_Nationse - Many Eultures, Scaroorough: Frentice Hall.

Vallee et a

1905

"Ethnic. Assimilation and Osffereotiation in Canada",

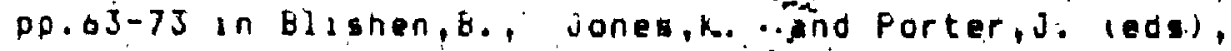

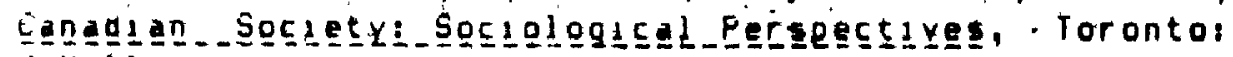
MeHillan. 
vallee, F.

"The Socsology of John Forteri Ethnsesty as Anachro-

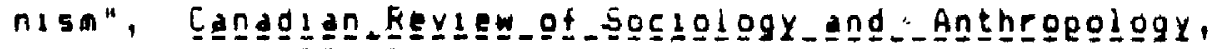
$18151, p \rho: 039-05 u$.

Wallian, S.

.1779 "The Scope for Ethnicity", pp. 1-14 in Wallati, S.

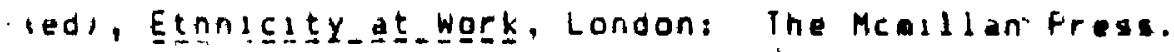

Wison, and Fortes, $M$.

lyuj "Iomigrant Enclaves: An Hnalysis of the Labor Market Experiences of Cubans in Muami", pp. 295-310, American

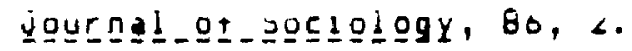

welnstock, H.

:405 "H Link between Hiceulturation ano Occupational 5 tatus",

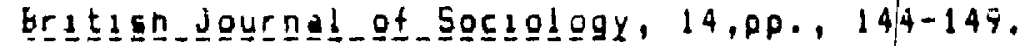

$w e d n+1 e d 0, M$.

Iyol Myth and Reality in the Canadaan Mosaca Aftectlve

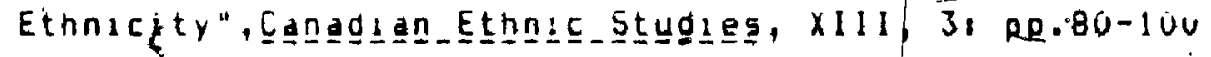

wuasworth, j. 5 .

$15 i$

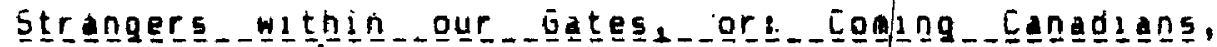
loronta: Ufiversity oi foronto fress. original edition puolished in 1905 .

iancev, W. Erickson, E. and Juliani; $F$.

lio "Enargent Ethnicity: H Feview and Formulation", Hmerlz

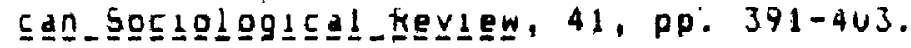




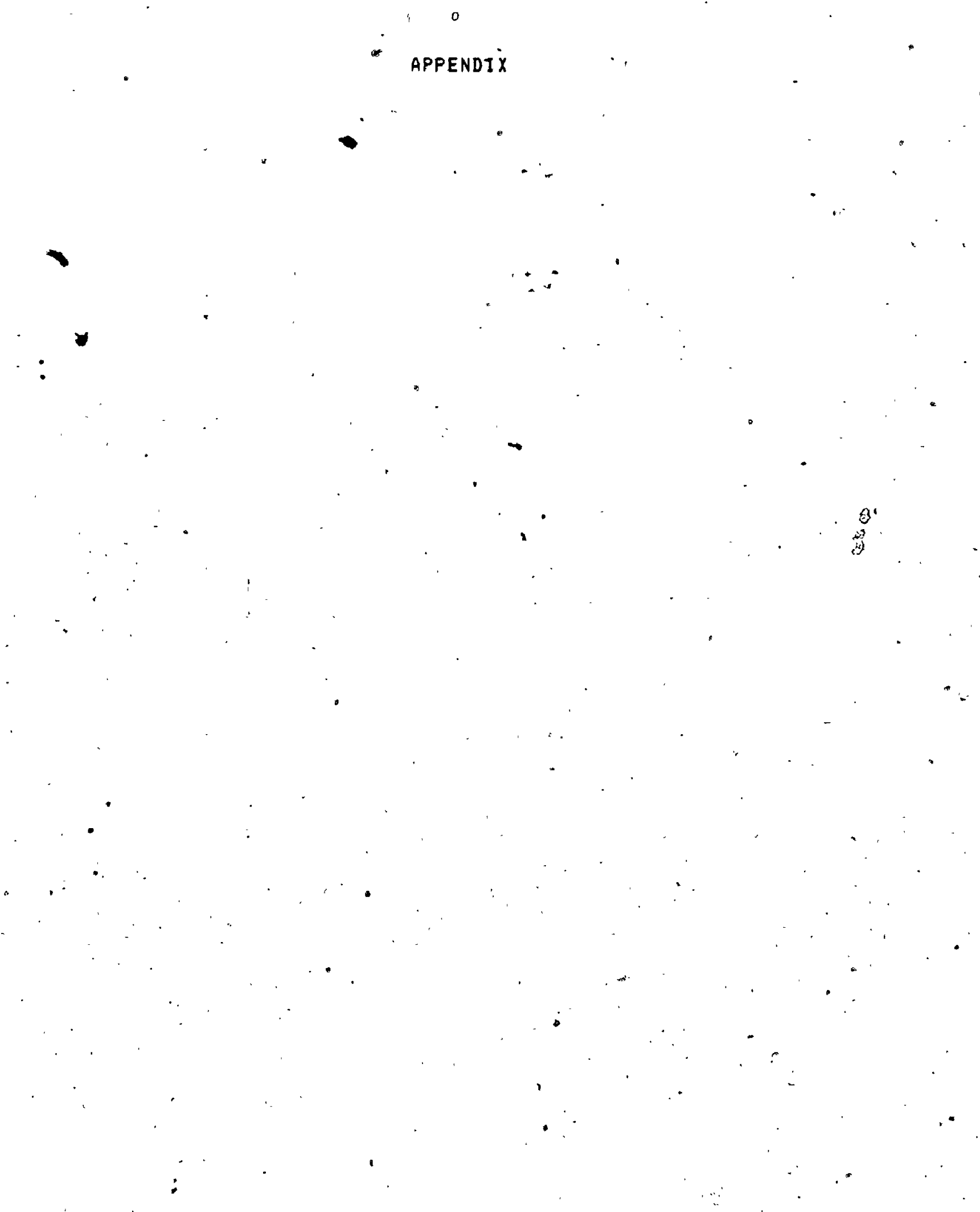




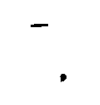

No:

Fecha

Sexo: $M 1, F(1$

Actualmente me encuentro cursando estudios de sociologia en Carleton University, : especlficamente an el área de inmigracion, grupos etnicos y Sociologla del Trabajo. En vista de la poca informacion quet existe en Canada sobre la poblacion española decidi escribir mi tesis acerca de la situación de este pequeño pero importante grupo en ottawa con la idea.de que quizas. sirva de base para futuros lestudios sobre 1a inmigracion española en otras cijudades canadienses. De antemaño le agradezco su colaboraciqn; toda la información que me sea suministrada sera completamente confidencial..

I) ANTECEDENTES PERSONALES Y PROCESO DE MIGRACION

1. Podria Ud por favor decirne

1.- Podria Ud. por favòr decirme en que año nacio? EDAD: a gends $30 \ldots \ldots 1$

$31-34 \ldots \ldots .2$

$45-54 \ldots \ldots 4$

$35-44 \ldots \ldots \ldots 3$

$55-59 \ldots \ldots 5$

60 y 1 m 3.6

2. - Donde racio Ud.? (Pais, region, ciudad ópueblo) 
4. - Actuclmente cual es su nacionalidad?

Española ( ).... Pasar a pregunta 5 .

. Canadiense 1 , ... Pasar a pregunta $5 a$.

Otra, cual?

5.- Ha pensado Ud. en hacerse ciudadano canadiense? ISONDEAR RAZONES)

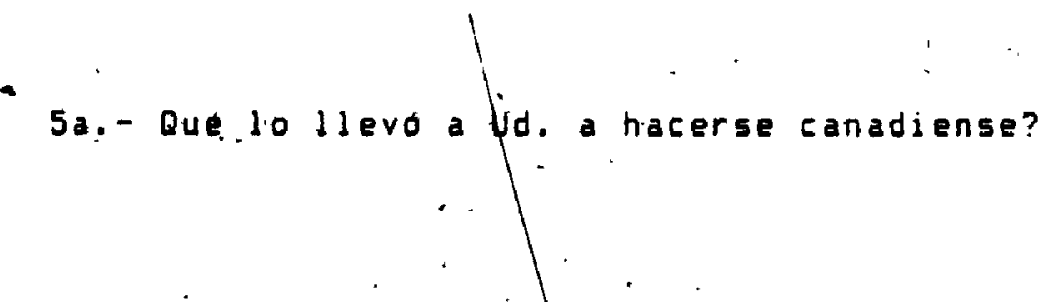

6.- Ahora vamos a hablar un poco acerca de su llegada a Canadá. En que año llego Ud. a este pass? Que edad tenfa Udi? ANO: EDAD:

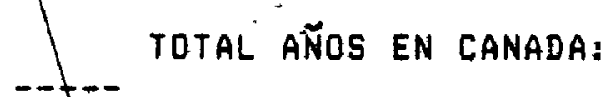

7.- Donde vivia Ud. antes de veñirse al Cañada? (ESPECIFICAR)

$\because$ España $\ldots \ldots \ldots \ldots \ldots \ldots$..........

Europa oecidental ......... 2

Latınoamerica ......... 3

Dtros, cual?

8. - Podrla Ud. por favor decifge porque decidio enigrar al. Canadí y no otro pais? ISONDEAR RAZONES, OBJETIVOS, TIPO DE INMIGRACION: 'INDEPENDIENTE, NOMINADA O SPONSORED) 
9.- A que sitio (region, ciudad) llego Ud. en el Canada? Ha vivido Ud. in otros lugares antes de residenciarse en

i Ottiaga? IŚNDEEAR RAZONES DE CAMBIO EN EL PASADÓ

- DE TIEMPOI.

10.- Cuanto tiempó ha vivido Ud. en Dttawa? ISONDEAR AREAS DE

- RESIdENCIA PREVIAS, RázONEs de CAMBIO, INTENCIONES de MUDANZAI).

11.- Le gusta a Ud, el area en donde vive actualmente? (SONDEAR MOTIVOS, PROPIEDAD DE LA VIVIENDA, IMPORTANCIAं O NO DE LOS VECINOSI.

12. - Vino Ud. al canada olo, o en compañia de otros faniliares? ISONDEAR EN EL CASD ESPECIFICO DE OTIAWA, RAZONES, CUANDO OCURRIO REUNION FAMILIAR EN CASO POSITIVOS. 
13. Aproximadamente cuantos familiares tiene Ud. en Canada? y en Ottawa? Podria Ud. decirme con que frecuencia los ve o tiene contacta con ellos? ISONDEAR NEXOS, OCASIONES, RAZONES)

Dıarja ........ 1

Semanal ...... 2

Mensual .........4 4

Quincenal ..... 3

Menos ........... 5

No tiene........

14. - Recien llegado a Canada, quien(es), le ayudaron en cuanto. a conseguir vivienda, trabajo, escuela, aprendizaje del idioma, etc.? ISONDEAR AYUDA INFORMAL V.I. FAMILIA, AMIGOS ESPAÑOLES U OT⿱RO ORIGIN; AYUDA FORMAL V.I. AGENCIAS DE GOBIERND, IGLESIA, ETC.)

15. - Cuantos años de estudio ha tenido Ud.? ISONDÉtar DONDE; TITSLO DBTENIDO?

$\because \begin{gathered}* \\ \vdots\end{gathered}$

Primarja ine. : : j

Téntica compdi.....6.

primaria compli... 2 ,

Univ.. Incompl. ..... $7 \cdot$.

Secundaria ine.... 3

Univ. compl......8 8 a.

Secundaria congl.. 4

Post-grado .......99

Técnica (artes y oficios) ins. 
16. - Que tipo de trabajo hacla Ud. en España lo sitio antarior de residencial antes de venirae a Canada? (SONDEAR SATISFACCION, INGRESO, NUMERO DE AÑOS, ANTECEDENTES OCUPACJONALES, EDAD COMENZO, TRABAJDEN.OTROS PAISES SI EMIGRO DIRECTAMENTE DE 'ESPAÑA)

II) SITUACION OCUPACIONAL EN CANADA

17. - Nos gustarla ahora hablar un poco sobre sus experiencias en O cuanto a trabajo. Cuando Ud. decidio venirse al Canada, que tipo de trabajo esperaba o querla encontrar? Cual era su idea con respecto a las posibilidades de trabajo? IESPECIFJCAR CUAL, : INGRESOS, CONDICIONES DE - TRABAJO EXPECTATIVAS, RAZOÑES)

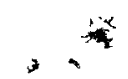

18.- Recuerda Ud. cúal fue su primer trabajo en Canada y como $10^{\circ}$ consiguio CÉSPECIFICAR LUGAR, OCUPACION ETNICA O' NO, : DIFICULTADES ENCONTRADAS, CUANTD TIEMPO TARDO \& EN ENCONTRARLO, FRICCIONES OTROS GRUPOS ETNICOS! 
19. - Aproximadanente cuanto tiempo esturo Ud. en ese primer trabajo? TSONDEAR RAZONES DE CAMBID, DIFICULTADES EN. GENERAL, CONDICIONES, DISCRIMINACION, ETC̀.)

20. - Haciendo un poco. de memoria, digame por tavor cuantos emplegs ha tenido Ud. en Canada Inó contando el primero y el. actuall? Para cada uno de ellos podria Ud. describir el tipo de trabajo, como lo consiguio $\neq$ las razones para dejarlo o cambiarse, arías del tiempo que paso. desempeñándolo?

OCUPACION

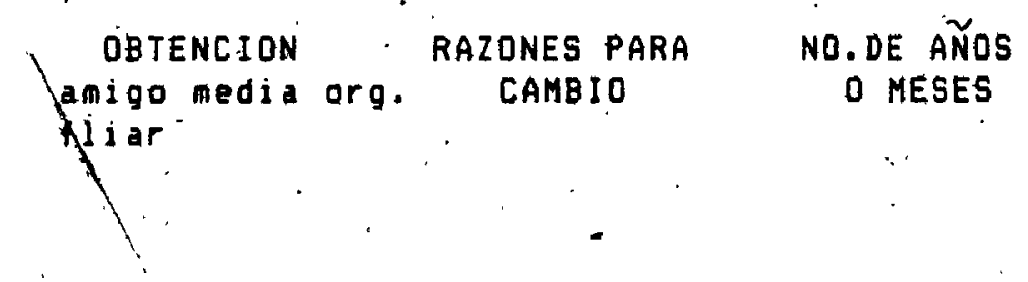

3/

4/

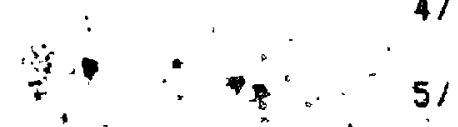

$+2$

$6 \%$

- Ha' estado Ud: alguna vez desempleado en Canada? ISONDEAR CUANDO, RAZÓNES, PERIDDO DE, TIEMPD, SEgURO DE DESEMPLEO, : ETC.) 
22. - Esta Ud. actualmente eopieado a tieapo completo, medio tieapo, o trabaja Ud, por cuenta prQpia? Que tipo de trabajo deseapeña Ud.? GEPECIFgCAR OCURACION, POSICION, LUGAR, TIPD DE NEGOCIO O EMPRESA, DESCRIPCION COMPLETA. EN CASO DE AMA DE CASA PASAR A PREG. 32. DESEMPLEADOS PASAR A PREG. 411

Status, Ocupacional (B1ishen)

23. - Actualmétie, tiene Ud. mas de un trabajo? ISONDEAR RAZONES, TIPQAEE EMPLEOS

24. - Aproximadanente fuántas horas trabaja Ud.? ISONDEAR SOAAETFEMPO, SAILSFACCION, DIFYCULTADES, ETC. ,

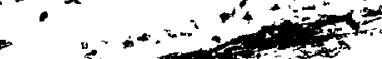

1

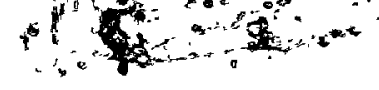

- 25.:- Como consiguio ud sü principal ocupacion o trabajo, es decif 13 que ocupd la árar parte de all tiempo? ISONDEAR AYUDA DE AMIGOS; FAMILIA O CANALES FORMALES, DIFICULTADES. ENCQNTRABAS, ETC.)

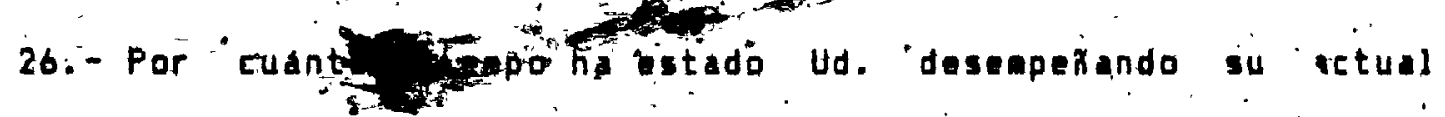
ocupacion? 0 
27. - Podria Ud. decirme si su patron o empleador es canadiense, espanol o de otra nacionalidad? y su supervisor inmediato? y sus companeros de trabajo en su mayoria?

ESPAÑDL CANADIENSE OTROS

\section{EMPLEADQR}

SUPERVISOR

COMPAÑEROS

28. - (SI POR CUENTA PROPIA)

'Trabaja.ud. en su propio negocio ..... 1

Le pertenece parcialmente ......... 2

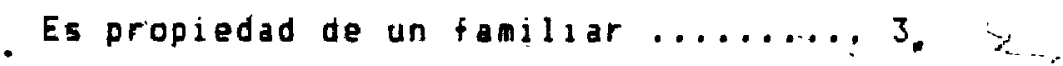

Otros, cual

29. - Dirla Ud. que la mayoria de los clientes son canadienses, eśpañoles, o de otro origen etnuco? "SONDEAR PORCENTAJE APROXIMADO, RAZONESI.

- 30. - Le voy. asostrar una tarjeta y Ud'. por favor va a decirme cual letra se aproxima nas al ingreso total. familiar durante

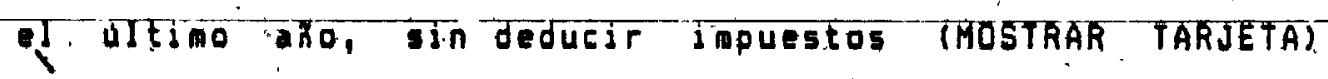
(INCLUIR TODOS LOS INGRESOS).

31:- Es Ud. la unica persona en el hogar que contribuye é el presupuesto familiar?" 'ISONDEAR QUIENES TRABAJAN, APORTE PRINCIPAL, INGRESOS ADICIONALES, ESPECIFICAR DONDE TRABAJAN OTROS"; ETG.) 
32.- Le pagad Ud. en su trabajo un salario, por hora, por pieza, por comision u otra forma de pagg? IPUEDEN SER VARIOS A LA VEZ, ESPECIFICAR RAZONES)

33. - En general dirja Ud. que esta contento con su actual trabajo aqul en Canada? (MOSTRAR TARJETA) (SONDEAR RAZONES)

34.-Cual seria para Ud. la ocupacion ideal, la que realmente le gustarla a Ud. desempeñar? IESPECIFICAh AREA, TIPO DE EMPRESA O NEGOCIO, CONDICIONES DE TRABAJD, INGRESO, ETC.

35. - Ha pensado Ud. en alguna oportunidad cambiar su ocupacion actual digamos en los proximos cinco años?. "isOndear RAZONES, TIPO DE TRÁBAJD, ETC:S.

36. - Suponiendo que un tamiliar biango suyo acabase de lleqar al Canada, que le aconsejarla Ud. en cuanto a obtención de enpleo y en general en cuanto a su adaptación al Canada. Que serla 10 mas importante a considerar en su opinion? (SONDEAR FACTORES PARA OBTENCION, MOBILIDAD, EXITO, ETC.)

37. - (SI CASADO) Es su-esposola tambien de arigen español? De donde es? ISONDEAR POSIBILIDAD DE EXOGAMIA, TIPO DE TRABAJO ACTUAL Y EN ESPANAI 
(SOLAMENTE PARA AMAS DE CASA, SIN OCUPACION ACTUAL)

38. - Cualles son las razones por las cuales no trabaja Ud. actualmente? (SONDEAR CAUSAS, DIFICULTADES, ETC)

39. - Que experiencia de trabajo tuvo Ud. en España o en el pais desde donde enigro al Canada? , IESPECIFICAR TIPO DE TRABAJO, SATISFACCION, RAZONES PARA NO TRABAJAR, ETC.)

40. - Quisiera Ud. trabajar si tuviera la oportunidad? (SONDEAR AREA, LUGAR, TIPO DE EMPLEADOR O PATRON, CONDILIONES)

41. (TODOs)Que piensa va. acerica de la "doble carga que significa para la mujer hacer el trabajo de la casa y tener que salir a trabajar al mismo tienpo? ISONDEAR. DIFICULTADES, CUIDADO DE LOS NIÑOS, AYUDA DEL MARIDOS

4Q. - Cuantos niños tiende Ud.? A que tipo de escuela asisten? ISONDEAR PUBLICA, PRIVADA, SEPARATE, INGLES O FRANCES, RAZONES, ESCUELA ETNICA, RAZDNESI 
MI) Lenguaje

43. - Cual era su conciniento de ingles, frances a su lî́egada al Canada? Dirla Ud. que era: (AUTOEVALUACION)

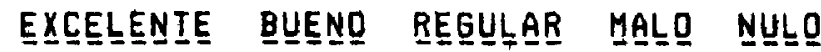

INGLES

FRANCES

44.- Asistio td. en el alguna oportunidad a clases de ingles o frances? ISONDEAR CUANDO, LUGAR, PROBLEMAS, OPINION GENERAL

45.- Generalnente que idiona se habla en la casa? ISONDEAR USO DE INGLES/FRANCES, ESPOSA/O, HJJUS, FRECUENCIA DE USO, RAZONES, ETC.)

46. - En su trabajo; con que frecuencia habla Ud. ingles/frances con su patrón, supervisor, compañeros, cldentes, ete.? (ESPECIFICAR PARA CAĹ UNO,- RAZONES, ETC.).

1

47. - En que ocasiones suele Ud, comunicarse en español? (SONDEAR

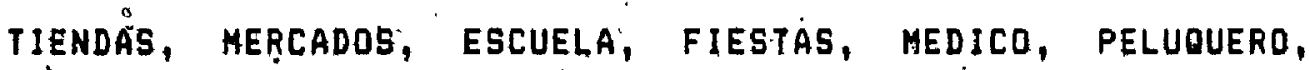
BANCO, SEguros; Garage, REPARACIONES DE LA CASA, ISLESIA, AGENCIA VIAJES, Y OTROS SERVICIOSI 
48. - Considera Ud. que puede hablar ingles/francés con fluidez actualmente o no? (SONDEAR LECTURA Y ESCRITURA, EVALUAR, MOSTRAR TARJETAY

Lẹtura Escrituguga

\begin{tabular}{l|llllllll} 
Ingles & 1 & 2 & 3 & 4 & 1 & 2 & 3 & 4 \\
frances & 1 & 2 & 3 & 4 & 1 & 2 & 3 & 4
\end{tabular}

Evaluacion'del entrevistador

IV) CULTURA ETNICA

49. - Mantiene Ud. algún contacto con otros españoles en Ottawa?

(RAZONES, PROCEDENCIA, QCASIONES, ETC.)

50. - Me gustarla ahora Ude Ud. pensara por un momento en sus tres mejores anigos/ast Fara cada uno de ellos"podria Ud. decirme de donde SdF (EXCLUIR FAMILIARES) () 2) 31

51.- Con.que frecuencia "visita Ud, a estas amigos y en que ocasioñes ISONDEAR RAZONES, TIPO DE. ACTIVIDADES, COMUNICACION TELEFONICA; ETC..)

52. - Tiene Ud. aaigos a algun tipode contacto con otros grupos EtnicOS? (ESPECIFICAR ORIGEN, DCASIONES, RAZONES, ETC.): 
53.- Ahora me gustarja conversar un poco sobre los grupos o asociaciones españolas a las que Ud. o sulfamilia pertenecén o conocen aunque sea de nombre: Para cada de ellas quisiera que me dijese durante cuanto tiempo ha participado, jas razones de pertenencia, la frecuencia de participacion, cuales miembros de la familia asisten a las celebraciones $y$ su opinion en general acerca de estas organizacioneso ISONDEAR SI ES MIEMBRO ACTIVD, AREA DE FARTICIPACION, DIFICULTADES, ETC.)

a) IGLESIA (SONDEAR CORO, LITURGIA, VISITAS ENFERMOS, FIESTAS Y OTRAS ACTIVIDADESI

b) CENTRO_ESPAÑOL:

c) ASQEIACIDNES_DEPQRTIVAS:

d) QIRAS_ASQCIACIDNES:

e) EMBAJADA: - (PARTICIPACION EN CELEGRACIONES, OTRAS OCASIONES, RAZONES, INSC., DEPTO LABQRAL)

54.- Dirja ud. que la mayorta de sus comidas diarias son tipicamente espaõolas, canadienses, o una combiñacion de amba's ISONDEAR CUALES COMIDAS ESPAÑLAS SUELE CONSUMIR, FRECUENCIA, LUGAR, DIFERENCIAS ENTRE MIEMBROS DEL HOGAR, CAMBIOS COMPARANDO P.RIMEROS AÑOS, BEBIDAS, ETC.) 
55:- Generalmente donde hace Uo. O su esposa la compra? ISONDEAR SERYICIO ETNICOS En donde adquiere Ud. JOS ingredientes para hacer platos tipicos españoles, vinos y otros productos españoles (especies, conservas, dulces, etc.)

56. - Acostubra Ud. a leer periodicos o revistas españolas ISONDEAR PUBLICACIONES EN ESPAÑA, CANADA Y OTROS PAISES DE

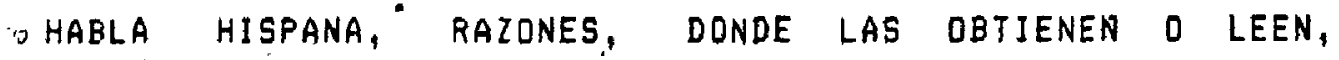
FRECUE,NCIA DE LECTURA, ETC.).

57. - Conoce Ud. o ha visto alguna vez programas españoles en la television canadiense? ISONDEAR, OPINION, FRECUENCIA, SUGERENCIAS, ETC. :

58.- En su opanion cree Ud. que hay una verdádera colonia o comunidad española en Ottawa? ISONDEAR RAZONES, EJEMPLOS DE. UNIDAO, AYUDA, COOPERACION, COMPARAR TOROONTO Y MONTREAL SI CONOCEN) 
59.- Piensi Ud. que exista aún tipo de trato diferencial con respecto extranjeros en Canada? IEN CASO POSITIVO HACIA QUIENES, EN QUE AREAS, OTTAWA ESPECIFICAMENTE, EXPERIENCIA PERSONAL, OPINION, ETC.)

-60. - Vamos a hablar ahora un poco sobre España, su pais de origen. Cuantas veces ha estado Ud. En España desde que so vino al Canadá? ISDNDEAR ULTIMA VEI, CON QUE FRECUENCIA VA, CUANTOS EN LA FAMILIA, ACTITUD NIÑOSI

61. - Cuales son las razones por las que viaja Ud. a España? Que es lo que a Ud. mas le gusta y lo que menios? (SONDEAR IMPRESIONES GENERALES)

62. - Le qustaria a Ud. quedarse permanentemente en Qttawa/canada en el futuro o por lo contrarjo piensa en regresar a España? ISONDEAR CUANDO, RAZONES, RAFERENCIA, L LOS HIJOS, RETIRO, PENSION, ETC.) 
63. - Aproximadamente a que edad ha pensado ud. en retirarse? (RAZONES)

64.- Cuales son. sus planes para cuando este retirado?

65. - En caso de regresarse a España, cono cree Ud. que viviria all comparado con su hivel y modo de vida en canada (RAZONES)

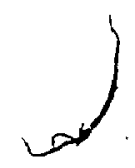

66. - Considera Ud. que desde que llego al Canadá han cambiado sus costumbres, habjtos, valores, en general su modo de ser $y$ penssar? Cuáles, especlficamente? ISONDEAR CAMBIOS ESPECIFICOS EN COMPARACION A ESPAÑA, IMPRESIONES Y OPINION AL RESPECTO)

67.- Podria Ud: decirme ahora, quées a lo que mas le ha costado acostuabrarse durantes los años que ha estado en -Canada, en cuanto a habitos, costumbres, valores y modo de vida en general? ISONDEAR DIFICULTADES O NO DE. ADAPTACION, SHOCK CULTURAL, COMPARACION Y OPINION EN GENERAL). 
68. - Volviendo un poco a su llegads al Canada, recuerda Ud. cono fué tratado por las autoridades canadienses y la' poblacion en general? ISONDEAR SEGREGACION POR ACENTO, RAZA, DONDE, COMO, ESPECIFICAR CUALES PROBLEMAS, ETC.)

69.- Podrla Ud. por favor decirme a cuales asociaciones canadienses pertence actualnente o pertenecio en el pasado? ISONDEAR RAZONES, QUIEN EN LA FAMILIA, DISCRIMINACION, FRECUENCIA. EN CASO NEGATIVO, AYUDAR: PARTIDÓ POL., SINDICATOS, VOLUNTARIOS DE HOSPITALES, ETC. YMCA," OTRAS DEPORTIVAS, ECONOMICS, PTA, CULTURALES, RËLIGIOSAS; CIVICAS (BLOCK PARENTS, CRIME), ETC.)

70.- Generalmente lee Ud. periodicos o revistas canadienses? ISONDEAR AMERICANAS, EUROPEAS U OTRO PAIS EN INGLES O FRANCES, FRECUENCIA, RAZONES, ETC.; 
71. - Que piensa Ud. acerca de Canada? Cual es su opinion sobre es te paIs? ISONDEAR SATISFACCION EN GENERAL; AREAS ESPECIFICAS: SALUD, EDUCACION, EMPLEO, ECONOMIA, IMPUESTOS, SEGURIDAD, VIVIENDA, ETC.) QUe es lo que mas le gusta? Y lo que menos le gusta?

72. - Cree Ud. que su situacion personal y familiar ha mejorado, ha empeorado, o ha sido.igual en jos ultimos diez años? (SONDEAR RAZONES)

OBSERVACIONES DEL ENTREVISTADOR:

- DURACION DE LA ENTREVISTA: $\cdot 8$

SUSTITUYE AL NUMERO:

RAZONES DE RECHAZO D IMPOSIBILIDAD DE REALIZACION: 

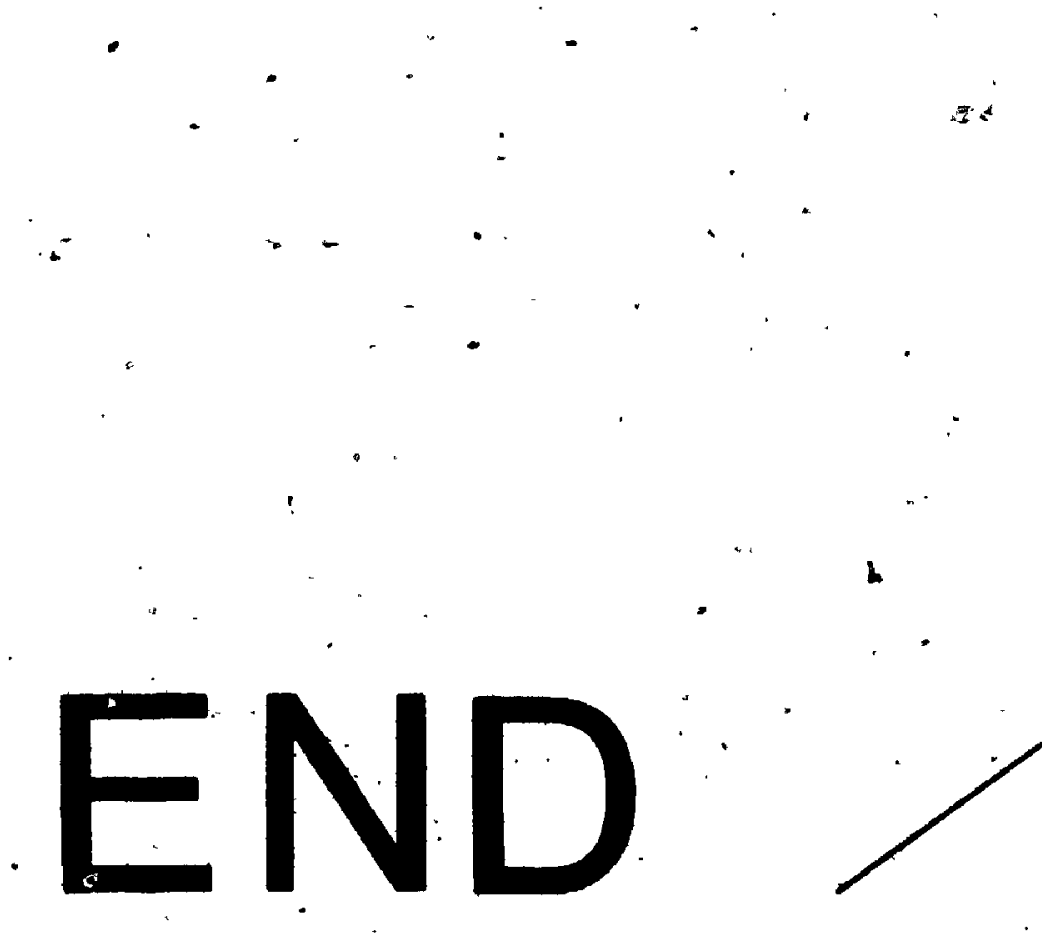